\author{
UNIVERSIDADE DE SÃO PAULO \\ FACULDADE DE FILOSOFIA, LETRAS E CIÊNCIAS HUMANAS \\ DEPARTAMENTO DE LETRAS CLÁSSICAS E VERNÁCULAS \\ PROGRAMA DE FILOLOGIA E LÍNGUA PORTUGUESA
}

\author{
MILEY ANTONIA ALMEIDA GUIMARÃES
}

Aspectos da fonologia do português como segunda língua por aprendizes anglófonos - uma análise via Teoria da Otimidade (versão corrigida)

São Paulo

2012 


\section{Aspectos da fonologia do português como segunda língua por aprendizes anglófonos - uma análise via Teoria da Otimidade}

(versão corrigida)

Dissertação de mestrado apresentada ao Departamento de Letras Clássicas e Vernáculas da Faculdade de Filosofia, Letras e Ciências Humanas da Universidade de São Paulo para obtenção do título de Mestre em Letras.

Área de Concentração: Filologia e Língua Portuguesa

Orientadora: Profa. Dra. Rosane de Sá Amado

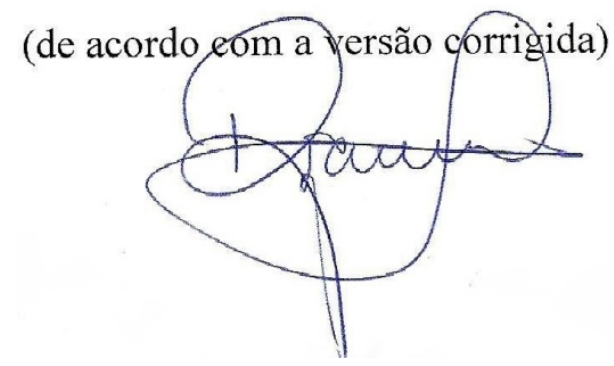

Exemplar original disponível no Centro de Apoio à Pesquisa em História (CAPH) da Faculdade de Filosofia, Letras e Ciências Humanas (FFLCH) 
Autorizo a reprodução e divulgação total ou parcial deste trabalho, por qualquer meio convencional ou eletrônico, para fins de estudo e pesquisa, desde que citada a fonte.

Catalogação da Publicação

Guimarães, Miley Antonia Almeida.

Aspectos da fonologia do português como segunda língua por aprendizes anglófonos - uma análise via Teoria da Otimidade / Miley Antonia Almeida Guimarães; orientadora Rosane de Sá Amado. - São Paulo, 2012.

$115 \mathrm{f}$.

Dissertação de mestrado apresentada ao Departamento de Letras Clássicas e Vernáculas da Faculdade de Filosofia, Letras e Ciências Humanas da Universidade de São Paulo para obtenção do título de Mestre em Letras. Área de Concentração: Filologia e Língua Portuguesa.

1. Língua Portuguesa. 2. Língua Inglesa. 3. Aquisição do Português como Segunda Língua por Falantes de Inglês. 4. Português como Segunda Língua. 5. Fonologia. 6. Teoria da Otimidade. 7. Vogais Nasais. 8. Assimilação de Vozeamento. I. Título. II. Amado, Rosane de Sá. 
GUIMARÃES, M. A. A. Aspectos da fonologia do português como segunda língua por aprendizes anglófonos - uma análise via Teoria da Otimidade. Dissertação apresentada ao Departamento de Letras Clássicas e Vernáculas da Faculdade de Filosofia, Letras e Ciências Humanas da Universidade de São Paulo para obtenção do título de Mestre em Letras.

Aprovada em 07 de novembro de 2012.

Banca Examinadora

Profa. Dra. Rosane de Sá Amado (presidente)

Instituição: Universidade de São Paulo - USP

Assinatura:

Prof. Dr. Ubiratã Kickhöfel Alves (titular)

Instituição: Universidade Federal do Rio Grande do SUL - UFRGS

Assinatura:

Prof. Dr. Paulo Chagas de Souza (titular)

Instituição: Universidade de São Paulo - USP

Assinatura: 
À minha mãe, Terezinha Almeida Guimarães in memoriam 


\section{AGRADECIMENTOS}

A Deus, pela força.

À minha tia Alaide, por todo auxílio, compreensão, disponibilidade e carinho.

À minha orientadora-inspiradora, Profa. Dra. Rosane de Sá Amado, pelo brilho nos olhos, pelo seu amor contagiante à docência e, especialmente, por ter confiado em mim, dando-me a liberdade necessária para desenvolver este trabalho.

Às minhas amigas queridas, Flávia, Mayra, Rosana, Valéria e Viviane, por terem entendido meus momentos de ausência. Meninas, voltei!

À minha irmã e ao meu pai, pelo apoio incondicional e, principalmente, pela paciência com minha falta de tempo e assunto nos últimos meses.

Ao pessoal do Grupo de Estudos de Português para Falantes de Outras Línguas (GE-PFOLUSP), em especial aos colegas que se tornaram amigos: Flávia, Gustavo, Juliana, Luhema, Neide, Pamela, Paola e Talita.

Aos Profs. Drs. Paulo Chagas de Souza e Waldemar Ferreira Netto, pela leitura criteriosa do meu relatório de qualificação e pela pertinência de seus comentários.

À Profa. Dra. Betty Salum, pela perspicácia e autenticidade, por suas aulas irem além de um curso de redação acadêmica para pós-graduação, por servirem para a vida.

À Coordenação de Aperfeiçoamento de Pessoal de Nível Superior (CAPES), por ter me concedido auxílio financeiro durante boa parte do mestrado.

Aos informantes desta pesquisa, que prontamente aceitaram participar das entrevistas.

Aos estrangeiros que, pelos mais variados motivos, escolheram o Brasil para viver por um tempo ou por toda a vida. É a eles, junto aos meus alunos e ex-alunos, a quem devo este trabalho.

Last but definitely not least, to Conn, for always being there for me, despite the miles and miles that insist on keeping us apart. Conn, a million special thanks go to you every hour of my day! 


\section{RESUMO}

GUIMARÃES, M. A. A. Aspectos da fonologia do português como segunda língua por aprendizes anglófonos - uma análise via Teoria da Otimidade. 2012. $115 \mathrm{f}$. Dissertação (Mestrado) - Faculdade de Filosofia, Letras e Ciências Humanas, Universidade de São Paulo, São Paulo, 2012.

Nesta dissertação, são analisados, via Teoria da Otimidade (MCCARTHY; PRINCE, 1995; PRINCE; SMOLENSKY, 1993), dois aspectos da fonologia do português como segunda língua por aprendizes americanos e britânicos: a ausência de assimilação regressiva de vozeamento envolvendo a fricativa alveolar final em posição de fronteira de palavra e a produção de oclusivas nasais em posição final e de fronteira de palavra. Em inglês, a fricativa alveolar /s/ em coda final diante de segmento sonoro tende a manter seu status de vozeamento subjacente (GIMSON; CRUTTENDEN, 2008; MYERS, 2010; ROCA; JOHNSON, 1999); em contrapartida, em português, a fricativa alveolar, nessa mesma posição, compartilha do traço de sonoridade do segmento à sua direita (BISOL, 2005; FERREIRA NETTO, 2001; MATTOSO CÂMARA JR., 2007 [1970]). Ademais, as oclusivas nasais [m, n] não são licenciadas em posição de coda em português, a não ser diante de segmentos que lhes sejam homorgânicos (BISOL, 2005; CAGLIARI, 2007; MATTOSO CÂMARA JR., 2007 [1970]); em inglês, no entanto, essas oclusivas nasais podem ocorrer independentemente do ponto de articulação do elemento seguinte (EWEN; HULST, 2001; GIMSON; CRUTTENDEN, 2008; ROCA; JOHNSON, 1999). Cabe, portanto, ao aprendiz anglófono do português como segunda língua adquirir processos fonético-fonológicos não presentes em sua primeira língua, passando a vozear a fricativa alveolar final diante de segmento sonoro, p. ex. 'mai[s] árvores' > 'mai[z] árvores', e a deixar de articular as oclusivas nasais em final de palavra, em favor da realização da vogal nasal do português, p. ex. 'co[m] arte' > 'c[õ̃̃ $]$ arte'. A partir do corpus, constituído por entrevistas com seis americanos e cinco britânicos, verificou-se que o tempo de residência no Brasil foi o fator mais significativo para a produção da fricativa alveolar vozeada e, juntamente com a qualidade da vogal, constituiu-se também como o fator mais relevante para a realização da vogal nasal. Pela análise da produção de aprendizes iniciantes, por meio do modelo baseado em restrições proposto pela Teoria da Otimidade, foi possível constatar a interação entre processos de marcação e de transferência do ranqueamento do inglês para a interlíngua do aprendiz.

Palavras-chave: aquisição/aprendizagem de segunda língua, português como segunda língua por anglófonos, fonologia, Teoria da Otimidade 


\begin{abstract}
GUIMARÃES, M. A. A. Aspects of the phonology of Portuguese as a second language by Anglophone speakers - an analysis within Optimality Theory framework. 2012. 115 pp. Master's Dissertation - Faculty of Philosophy, Letters and Human Sciences, University of São Paulo, São Paulo, 2012.
\end{abstract}

In this dissertation, two phonological aspects of Portuguese as a second language by American and British learners are analysed within Optimality Theory framework (MCCARTHY; PRINCE, 1995; PRINCE; SMOLENSKY, 1993): the lack of regressive voicing assimilation involving the final alveolar fricative in word-boundary context and the production of nasal stops in word-final and word-boundary contexts. In English, the alveolar fricative /s/ in word-final position preceding a voiced segment tends to maintain its underlying voicing value (GIMSON; CRUTTENDEN, 2008; MYERS, 2010; ROCA; JOHNSON, 1999); conversely, in Portuguese, the alveolar fricative in this same position agrees in voicing with the following segment (BISOL, 2005; FERREIRA NETTO, 2001; MATTOSO CÂMARA JR., 2007 [1970]). Moreover, the nasal stops [m, n] are not allowed in coda position in Portuguese, unless they precede homorganic segments (BISOL, 2005; CAGLIARI, 2007; MATTOSO CÂMARA JR., 2007 [1970]); on the other hand, in English, these nasal stops can occur regardless of the next segment's place of articulation (EWEN; HULST, 2001; GIMSON; CRUTTENDEN, 2008; ROCA; JOHNSON, 1999). Therefore, the Anglophone learner of Portuguese as a second language is given the task of acquiring phonetic/phonological processes not present in their first language, having to voice the final alveolar fricative which precedes a voiced segment, e. g. mai[s] árvores $>$ mai[z] árvores 'more trees', and to cease producing nasal stops in word-final position in favour of the production of Portuguese nasal vowels, co[m] arte > c[õ̃w] arte 'with art'. From the corpus, consisting of interviews with six American and five British learners, it was demonstrated that the time of residence in Brazil was the most significant factor for the production of the voiced alveolar fricative, and together with the quality of the vowel, it was also shown to be the most relevant factor in the production of the nasal vowel. Analysing the production of beginning learners within Optimality Theory constraint-based model, it was possible to attest the interaction between markedness effects and transfer of the English constraint ranking to the learner's interlanguage.

Keywords: second language acquisition, Portuguese as a second language by Anglophone speakers, phonology, Optimality Theory 


\section{LISTA DE ILUSTRAÇÕES}

\section{FIGURAS}

Figura 1.1 - Processos de transferência (interference) e desenvolvimento (developmental) de acordo com o tempo de aprendizagem (MAJOR,

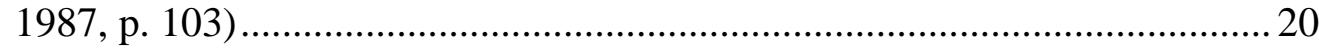

Figura 1.2 - Esquema de funcionamento da gramática proposto pela TO (ARCHANGELI, 1999, p. 534)................................................................... 24

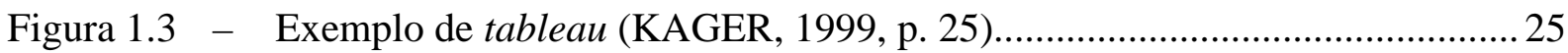

Figura 1.4 - Assimilação regressiva de vozeamento (PB)................................................ 30

\section{GRÁFICOS}

Gráfico 3.1 - Número de ocorrências de [s] e [z] finais antecedendo segmento vozeado em relação ao tempo de residência no Brasil

Gráfico 3.2 - Número de ocorrências (de tentativas) de realização de /eN/, /iN/, /oN/ e /uN/ por informante em posição final e de fronteira de palavra

Gráfico 3.3 - Realização da sequência /aN/ por informante em posição final e de fronteira de palavra

\section{QUADROS}

Quadro 1.1 - Manifestação de /VN/ em interior de palavra em PB ..................................... 38

Quadro 1.2 - Manifestação de /VN/ em final e em fronteira de palavra em PB .................. 39

Quadro 2.1 - Informações sobre os informantes .............................................................4

Quadro 3.1 - Informantes que produziram vogal + [n] em posição final de palavra........... 54 


\section{LISTA DE TABELAS}

Tabela 3.1 - Resultados de frequência e peso relativo para a aplicação de [z] pelos informantes em posição de fronteira de palavra em relação a fatores linguísticos e extralinguísticos

Tabela 3.2 - Número e porcentagem de ocorrências das variáveis para a vogal nasal produzida pelos informantes em posição final e de fronteira de palavra ....... 55

Tabela 3.3 - Resultados de frequência e peso relativo para a aplicação de vogal nasal + [m] pelos informantes em posição final e de fronteira de palavra em relação a fatores linguísticos e extralinguísticos

Tabela 3.4 - Resultados de frequência e peso relativo para a aplicação do ditongo nasalizado pelos informantes em posição final e de fronteira de palavra em relação a fatores linguísticos e extralinguísticos 
1.1 A INTERLÍNGUA

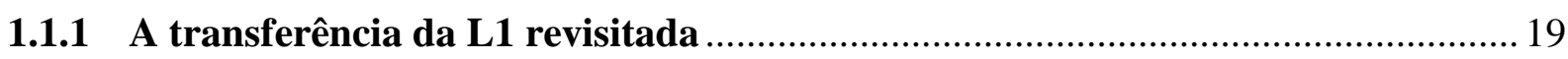

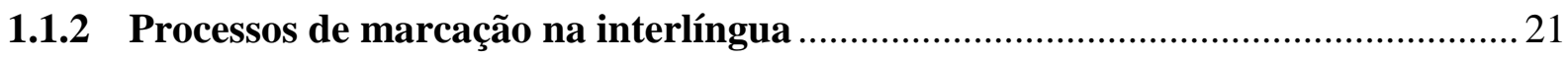

1.2 TEORIA DA OTIMIDADE E AQUISIÇÃO DA FONOLOGIA DE L2 ....................23

1.2.1 Teoria da Otimidade - pressupostos fundamentais ............................................ 23

1.2.2 Aquisição da fonologia de L2 via Teoria da Otimidade .................................... 26

1.3 VOZEAMENTO E NASALIDADE EM CODA EM PB E INGLÊS ..........................29

1.3.1 Status do vozeamento de obstruintes em coda silábica..........................................29

1.3.1.1 Neutralização e assimilação de vozeamento em PB ................................................... 29

1.3.1.2 Vozeamento irrestrito e "assimilação de desvozeamento" em inglês............................ 32

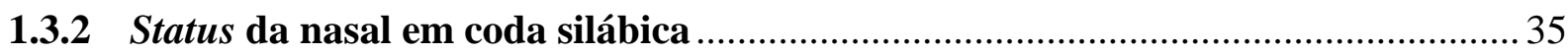

1.3.2.1 A vogal nasal e o arquifonema /N/ em PB ............................................................... 35

1.3.2.2 As oclusivas nasais em coda final em inglês ............................................................. 41

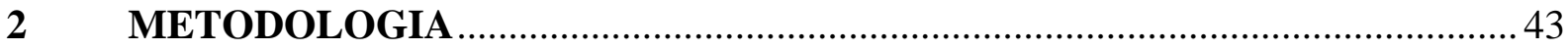

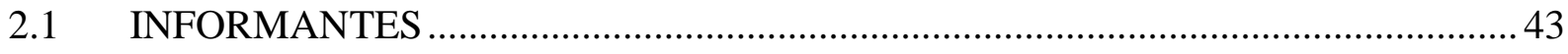

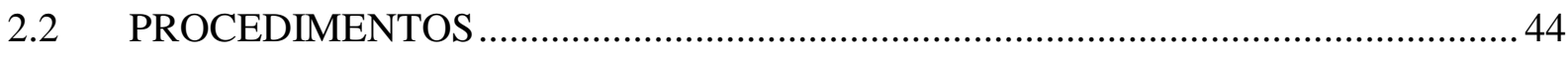

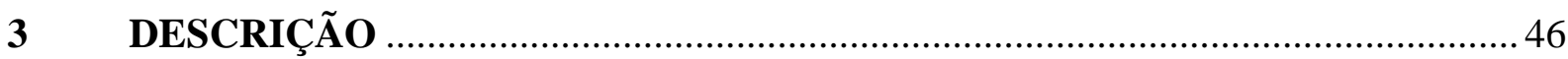

3.1 O (NÃO) VOZEAMENTO DA FRICATIVA ALVEOLAR EM POSIÇÃO DE FRONTEIRA DE PALAVRA NA INTERLÍNGUA DOS INFORMANTES ............46

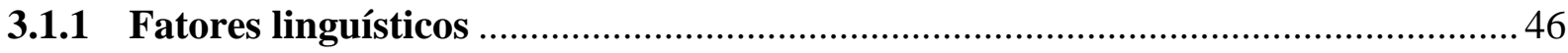

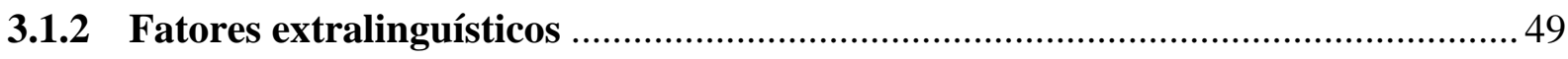

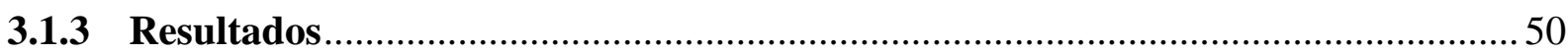

3.2 A PRODUÇÃO DA NASAL EM POSIÇÃO FINAL E DE FRONTEIRA DE PALAVRA NA INTERLÍNGUA DOS INFORMANTES ....................................... 53

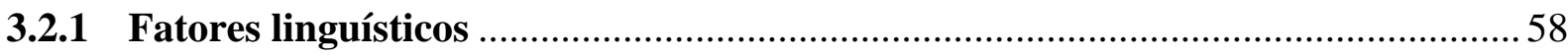


3.2.3.1 Produção da vogal nasal + oclusiva bilabial [m] em posição final e de fronteira de palavra.

3.2.3.2 Produção da vogal nasal + glide em posição final e de fronteira de palavra..... 62

4 ANÁLISE. 65

4.1 ANÁLISE VIA TEORIA DA OTIMIDADE DO (NÃO) VOZEAMENTO DA FRICATIVA ALVEOLAR EM POSIÇÃO DE FRONTEIRA DE PALAVRA 65

4.1.1 Formalização da hierarquia de restrições para o PB e para o inglês 66

4.1.1.1 Neutralização e contraste em posição final de palavra .................................................66

4.1.1.2 Concordância de vozeamento em cluster ................................................................... 70

4.1.2 Formalização da hierarquia de restrições para a interlíngua ............................... 80

4.2 ANÁLISE VIA TEORIA DA OTIMIDADE DA PRODUÇÃO DA NASAL EM POSIÇÃO FINAL E DE FRONTEIRA DE PALAVRA ............................................ 86

4.2.1 Formalização da hierarquia de restrições para o PB e para o inglês .................... 86

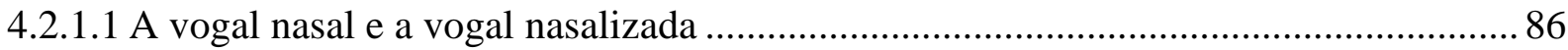

4.2.1.2 Assimilação de ponto de articulação das nasais ........................................................95

4.2.2 Formalização da hierarquia de restrições para a interlíngua ............................. 101

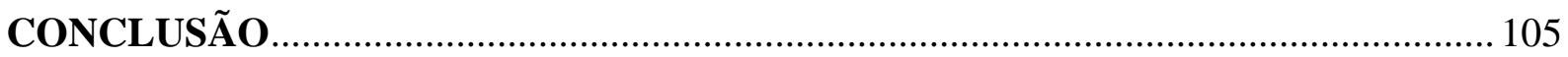

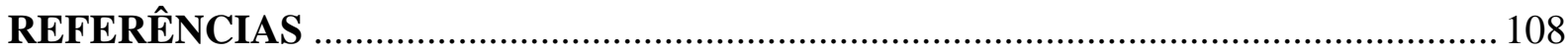




\section{INTRODUÇÃO}

Nesta dissertação, são analisados dois aspectos recorrentes na fonologia do português como segunda língua (PL2) por falantes americanos e britânicos: a ausência de assimilação regressiva de vozeamento da fricativa alveolar final diante de palavra iniciada por segmento sonoro e a produção de oclusivas nasais em posição final e de fronteira de palavra. Postula-se que essas características da fala de aprendizes anglófonos de PL2 possam ser explicadas, via Teoria da Otimidade (TO) (MCCARTHY; PRINCE, 1995; PRINCE; SMOLENSKY, 1993), por processos de marcação e de transferência do ranqueamento de restrições da primeira língua (L1) para a segunda língua (L2) do aprendiz ${ }^{1}$.

É dado consensual na literatura em fonologia do português que a fricativa coronal em coda diante de segmento vozeado realize-se sistematicamente como vozeada, tanto em interior como em fronteira de palavra, p. ex. 'me[z]mo', 'mai[z] dois' (ou 'me[3]mo' e 'mai[3] dois', a depender da variante regional) (BISOL, 2005; FERREIRA NETTO, 2001; MATTOSO CÂMARA JR., 2007 [1970]). De acordo com Santos (2007) e Silva (2008), esse é um processo adquirido por falantes nativos do português brasileiro (PB) durante os estágios iniciais de aquisição do idioma como L1, constituindo-se, portanto, em um processo fonológico, e não de motivação apenas fonética. Não é uma característica da fonologia do inglês, por exemplo, esse tipo de assimilação regressiva, especialmente no que concerne ao contexto de fronteira de palavra (GIMSON; CRUTTENDEN, 2008; MYERS, 2010; ROCA; JOHNSON, 1999).

Ademais, tanto em PB como em português europeu, aceita-se que as oclusivas nasais ${ }^{2}$ bilabial [m] e dental [n] ocorram em coda apenas precedendo segmento que lhes sejam homorgânicos em ponto de articulação, p. ex. 'ca[m]po’, em que há compartilhamento do traço bilabial da consoante seguinte, e 'me[n]ta', em que o traço dental é compartilhado (BISOL, 2005; CAGLIARI, 2007; MATEUS; d’ANDRADE, 2000; MATTOSO CÂMARA JR., 2007 [1970]). Essa característica, de acordo com Cagliari (2007), pode se estender à posição de fronteira de palavra, p. ex. ‘so[m] baixo’ e ‘co[n] todos’. De outro modo, diante

\footnotetext{
${ }^{1}$ O termo primeira língua (L1) corresponde à língua materna do falante, já o termo segunda língua (L2) referese, neste trabalho, ao idioma estrangeiro aprendido em ambiente de imersão no país em que é a língua nativa de seus habitantes, tal como o português aprendido no Brasil por anglófonos e hispanofalantes. Os termos aprendizagem e aquisição são aqui tratados como sinônimos.

${ }^{2}$ Por ser salientado, neste trabalho, o fato de haver bloqueio oral durante a realização das consoantes nasais, optou-se pelo termo oclusivas nasais, que aqui não se deve contrapor à consideração de que esses segmentos também sejam soantes.
} 
de pausa ou de segmento que não lhes sejam homorgânicos, as oclusivas nasais [m, n] não ocorrem em posição de coda final em português ${ }^{3}$. Em contrapartida, em inglês, as duas oclusivas são licenciadas em posição final, p. ex. [w^n] one 'um', [g.ðum] groom 'noivo’, e de fronteira de palavra [w^n æktə] one actor 'um ator', [ka:m deız] calm days 'dias calmos', estando ou não diante de segmentos que lhes sejam homorgânicos (EWEN; HULST, 2001; GIMSON; CRUTTENDEN, 2008; ROCA; JOHNSON, 1999).

Segundo compilação realizada por Albano et al. (1995), a partir do Minidicionário Aurélio e de 57 gravações do Projeto NURC, /N/ e /S/ ${ }^{4}$ caracterizam-se como as produções em coda silábica mais frequentes em PB, respondendo juntas por mais da metade do total de ocorrências nessa posição. No Minidicionário Aurélio, /N/ corresponde a 39,4\% das realizações em coda e /S/ a 17,8\%. No Projeto NURC, esses elementos constituem, respectivamente, $37,3 \%$ e $22,9 \%$ do total de realizações em coda. Em seguida, estão as produções de /r/, /u/, /l/, e /i/, nessa ordem.

Pretende-se nesta dissertação verificar como as duas codas silábicas mais produtivas em $\mathrm{PB}$, /N/ e /S/, sujeitas a processos fonético-fonológicos de assimilação de ponto de articulação e de vozeamento, respectivamente, manifestam-se na fala do aprendiz anglófono de PL2.

Vale ressaltar que, além de processos assimilatórios, ocorrem no contexto linguístico de fronteira de palavra, processos de ressilabificação, em que a coda final torna-se onset da sílaba seguinte, p. ex. 'mais amor', realizado como [maj.za'mor]. A ressilabificação é um processo importante, pois se correlaciona diretamente à inteligibilidade do aprendiz de PL2. Em onset, em português, há contraste de vozeamento entre [s] e [z] e de ponto de articulação entre [m] e [n], apenas em coda esses contrastes se neutralizam (BISOL, 2005; CAGLIARI, 2007; MATTOSO CÂMARA JR., 2007 [1970]). Assim, 'mas uma’ produzido pelo falante anglófono como 'ma[s] uma' pode ser interpretado como 'mas suma' pelo falante nativo de português, e a produção de uma oclusiva nasal, como em 'um ano', realizado como 'u[m] ano', pode, por exemplo, levar a sequência de palavras a ser percebida como 'humano'. Entende-se que diferenças entre duas línguas no que concerne à constituição da estrutura silábica e à presença ou ausência de processos assimilatórios estão entre os fatores que afetam

\footnotetext{
${ }^{3}$ Cagliari (2007) atenta para o fato de que após uma vogal posterior fechada e diante de pausa, [m] pode ocorrer, p. ex. 'rum' [xũm], constituindo-se em um contexto excepcional.

${ }^{4} \mathrm{O}$ arquifonema /N/ representa a neutralização do ponto de articulação da consoante nasal, que, em português, é especificada em onset [m, n, n], mas não em coda; já o arquifonema /S/ representa os segmentos em coda [s, z] e $\left[\int, 3\right]$, a depender da variante dialetal do português.
} 
substancialmente a produção em L2, por ocasionarem modificação na identidade das palavras (GIMSON; CRUTTENDEN, 2008).

Este trabalho tem por base um corpus constituído por entrevistas realizadas por esta pesquisadora com 11 aprendizes anglófonos de PL2, seis americanos e cinco ingleses, todos residentes na cidade de São Paulo no momento da coleta de dados. Embora diversos tenham sido os aspectos fonético-fonológicos observados na produção oral do grupo de entrevistados, nenhum deles teve uma quantidade de ocorrências igual ou superior à realização de [m, n] em coda final diante de pausa ou de elemento não homorgânico, aspecto presente em dado momento da produção oral de dez informantes, e à realização da fricativa alveolar não vozeada, [s], diante de palavra iniciada por segmento vozeado, ocorrência encontrada em dado momento da fala de todos eles.

Apesar de a aquisição de aspectos fonético-fonológicos ser tema privilegiado na literatura em aquisição de L2, a pesquisa sobre a produção dos sons em PL2 por aprendizes anglófonos permanece incipiente, geralmente baseando-se nos modelos de Análise Contrastiva (LADO, 1957) ou de Análise de Erros (CORDER, 1967). Nesses trabalhos, os desvios dos aprendizes ora são descritos e comparados com a estrutura da língua inglesa (AZEVEDO, 1981; FERREIRA, 2006), ora são classificados com a intenção de identificarlhes a origem (DUTRA, 2009; CAMARGO, 2009). Acredita-se que esses sejam passos essenciais para o entendimento da produção linguística de aprendizes anglófonos de PL2, mas a testagem de novos modelos é fundamental para o avanço da pesquisa na área.

Diante do exposto, somado à ausência de estudos que tratem, especificamente, de aspectos da fonologia em posição final e de fronteira de palavra pelo aprendiz anglófono de PL2, optou-se pela pesquisa desse tema no mestrado, utilizando, para isso, um modelo linguístico relativamente novo, a Teoria da Otimidade (TO) (MCCARTHY; PRINCE, 1995; PRINCE; SMOLENSKY, 1993).

Originalmente elaborada como um modelo sobre o funcionamento da gramática das línguas naturais, i. e. sobre a faculdade da linguagem em relacionar forma subjacente à forma de superfície, a TO tem gradativamente aumentado seu número de adeptos também na área de aquisição de L2. Em sua versão standard, na qual este trabalho fundamentalmente se baseia, parte-se do pressuposto de que existam restrições universais, ou seja, propriedades e padrões fonológicos comuns em todas as línguas, as quais são ranqueadas ou hierarquizadas de forma particular em cada uma delas. Por estarem dispostas em posições diferentes nesses ranqueamentos, nem todas as restrições se manifestam da mesma forma nas línguas, o que explicaria a variação existente entre elas (ARCHANGELI, 2003 [1997], p. 3). 
A TO, seguindo modelos linguísticos anteriores, como o gerativista (CHOMSKY, 1959; CHOMSKY; HALLE, 1968), propõe então que haja uma forma subjacente (input), uma forma de superfície (output) e uma relação entre essas duas formas. No entanto, abstém-se de regras, propondo uma hierarquia de restrições violáveis referentes à boa formação de estruturas linguísticas. Nessa proposta, as formas de output são geradas por meio do conflito entre restrições que militam a favor de formas não marcadas e restrições que militam a favor da manutenção da identidade do input. Aprender uma língua seria adquirir sua hierarquia de restrições.

Pesquisadores que adotam a TO como modelo para a análise de dados em aquisição de L2 geralmente assumem que o aprendiz utiliza-se da mesma hierarquia de restrições de sua L1 no início da aprendizagem da L2 (BROSELOW et al., 1998; DAVIDSON et al., 2004; HANCIN-BHATT, 2008; HANCIN-BHATT; BHATT, 1997; PATER, 1997). Em inglês, por exemplo, obstruintes vozeadas finais são permitidas, [god] good 'bom', indicando que a restrição universal de marcação que impede obstruintes vozeadas nesse contexto está em posição baixa na hierarquia do idioma, sendo violada em favor da restrição de fidelidade que requer correspondência entre a forma subjacente, /gud/, e a forma de superfície, [god]. Aprendizes de inglês como L2 cuja L1 não permite obstruintes vozeadas finais, o que demonstra que a restrição que milita contra obstruintes vozeadas finais ocupa posição prioritária na hierarquia, podem produzir [got] para good, transferindo assim a hierarquia de restrições da L1 para o inglês como L2.

Por lidar com princípios universais de marcação, a TO revela-se também como um modelo capaz de explicar a emergência de padrões não marcados, característica inerente ao sistema linguístico do aprendiz de L2 (ECKMAN, 1987; MAJOR, 2001). De acordo com Broselow et al. (1998), a tendência apresentada por muitos aprendizes de L2 em favorecer estruturas menos marcadas, as quais podem inclusive não estar presentes nem na L1 nem na L2 do falante, pode ser explicitada pelo modelo de TO por meio do conflito entre restrições de marcação e de fidelidade.

Considerando, finalmente, que a interação entre fenômenos de transferência e de marcação - processos frequentes, principalmente no início da aquisição de L2 -, possa ser evidenciada pelo modelo de TO, esta dissertação tem como objetivo principal explicitar a atuação desses dois fenômenos, de transferência e de marcação, na ausência de assimilação regressiva de vozeamento e na produção de oclusivas nasais finais pelo aprendiz anglófono de PL2 em seu primeiro estágio de aquisição, classificado aqui pelo tempo de três meses de residência do aprendiz no Brasil. 
Este trabalho não se ocupa, portanto, da formalização via TO das diversas etapas desenvolvimentais pelas quais passam os aprendizes, limitando-se à formalização do seu ranqueamento de restrições inicial, o qual, contudo, pode ainda exercer influência nas etapas posteriores de aprendizagem do PL2, dada a variação que permanece na fala de aprendizes mais experientes, com tempo de residência no Brasil superior a 20 anos.

Os objetivos específicos desta pesquisa são:

- extrair dos dados dos informantes as ocorrências de fricativas alveolares finais (surdas e sonoras) diante de palavra iniciada por segmento sonoro ${ }^{5}$;

- extrair dos dados dos informantes as tentativas de produção de vogal nasal + /N/ em posição final e de fronteira de palavra;

- identificar fatores linguísticos e extralinguísticos que possam se correlacionar com os dados, por meio do programa de análise estatística de dados linguísticos Goldvarb (SANKOFF et al., 2005);

- apresentar o ranqueamento de restrições para o PB e o ranqueamento de restrições para o inglês referentes ao vozeamento de obstruintes finais;

- apresentar o ranqueamento de restrições para o PB e o ranqueamento de restrições para o inglês referentes à produção de consoantes nasais em coda, bem como à produção de vogais nasais/nasalizadas;

- estabelecer o ranqueamento de restrições para o sistema linguístico do aprendiz anglófono, em seu primeiro estágio de aquisição, referente à ausência de assimilação regressiva de vozeamento em posição de fronteira de palavra;

- estabelecer o ranqueamento de restrições para o sistema linguístico do aprendiz anglófono, em seu primeiro estágio de aquisição, referente à produção das oclusivas nasais [m, n] em posição final e de fronteira de palavra.

Esta dissertação está dividida em quatro capítulos. O capítulo 1, "Fundamentação Teórica”, inicia-se com o subcapítulo “Interlíngua”, em que são apresentadas as principais características do sistema linguístico do aprendiz de L2, destacando a transferência da L1 e fenômenos de marcação. No subcapítulo “Teoria da Otimidade e aquisição da fonologia de L2”, os principais conceitos da TO são expostos, assim como sua pertinência na área de aquisição de L2. Em seguida, no subcapítulo intitulado "Vozeamento e nasalidade em coda em PB e inglês” são apresentadas as especificidades dos dois idiomas concernentes a

\footnotetext{
${ }^{5}$ Neste trabalho, as palavras sonoridade e vozeamento são tratadas como sinônimos, assim como os pares sonoro/vozeado e surdo/desvozeado.
} 
processos fonológicos relacionados ao vozeamento e à nasalidade nessa posição da sílaba. A "Metodologia”, com informações sobre os informantes e os procedimentos utilizados na coleta de dados e análise, constitui o capítulo 2. No capítulo 3, a produção dos informantes é descrita e, no capítulo 4, é realizada a análise via TO dos dois aspectos do PL2 por aprendizes anglófonos aqui propostos a serem estudados: a ausência de assimilação regressiva de vozeamento envolvendo a fricativa alveolar final diante de segmento vozeado e a produção dos segmentos nasais [m, n] em posição final e de fronteira de palavra. Em seguida, encerrase este trabalho com a conclusão. 


\section{FUNDAMENTAÇÃO TEÓRICA}

\subsection{A INTERLÍNGUA}

A produção linguística do aprendiz de L2, doravante interlíngua, foi considerada de início como resultante apenas da transferência da L1 (LADO, 1957) e, um pouco mais tarde, da interação entre L1 e L2 (SELINKER, 1972). Com o avanço da pesquisa na área, o conceito passou a abarcar diversas outras características.

A partir dos trabalhos de Corder $(1967,1981)$, a interlíngua passou a ser caracterizada como um sistema formado por regras próprias e regras compartilhadas com outras gramáticas. Corder assume que, embora a interlíngua possua caráter instável, de variação entre indivíduos e até mesmo intraindividual, podem ser encontradas semelhanças na produção de aprendizes que estejam em uma mesma etapa de desenvolvimento da aprendizagem, independentemente de sua L1. O autor também ressalta que a interlíngua não é apenas resultado da transferência e da interação entre L1 e L2, mas constitui-se como um sistema com suas próprias características e história de desenvolvimento.

O caráter variável da interlíngua veio a ser constantemente enfatizado na pesquisa em aquisição de L2. Larsen-Freeman (1997), por exemplo, trata do fenômeno de aquisição de L2 sob o viés da teoria da complexidade e dos sistemas dinâmicos. A autora assume que a interlíngua é um sistema com inúmeros fatores interagindo de forma interdependente: a L1, a L2, processos de marcação, instrução formal, input recebido, contexto sociointeracional, idade de início do processo de aquisição, motivação, estratégias de aprendizagem, entre outros, sendo que a alteração em um desses componentes pode mudar todo o sistema, fazendo com que a previsão de situações futuras torne-se bastante limitada. De acordo com a autora, em função do tempo e da interação entre diversas variáveis, há aleatoriedade e imprevisibilidade, mas, ainda assim, há reestruturação e ordem, o que poderia explicar um padrão inter- e intraindividual também encontrado.

Assume-se neste trabalho o papel importante que a variação possui na interlíngua, o que ficará demonstrado especialmente na parte de descrição dos dados. No entanto, da gama de fatores que constitui o processo de aquisição de L2, ressaltam-se dois aspectos frequentemente tidos como de peso relevante na produção interlinguística do aprendiz: a transferência de L1 e os processos de marcação, dos quais esta seção se ocupa. 


\subsubsection{A transferência da $\mathrm{L} 1$ revisitada}

O grau de importância dado à transferência de aspectos fonéticos, morfológicos, sintáticos e lexicais da L1 para a L2 tem variado de acordo com teorias e modelos linguísticos vigentes.

Na Análise Contrastiva (AC) (LADO, 1957), modelo em que foi primeiramente formalizada, a transferência da L1 foi tida como única origem para os desvios dos aprendizes. Por meio do contraste entre L1 e L2, presumia-se que os erros dos aprendizes pudessem ser previstos e, assumindo caráter pedagógico, propunha-se que fossem ensinados os aspectos da L2 que se diferenciavam da L1, estabelecendo-se assim novos hábitos linguísticos nos aprendizes e evitando-se o surgimento de erros.

Constata-se mais tarde, com base nos estudos gerativistas de Chomsky (1959), que a aquisição de L2, tal como a aquisição de L1, é um processo criativo, de formulação e comprovação de hipóteses, e não um processo comportamental, resultante da aquisição de novos hábitos linguísticos. Essa constatação, aliada à ocorrência de uma quantidade significativa de erros em L2 não previstos pela AC, fez surgir um novo modelo: o Modelo de Análise de Erros (AE) (CORDER, 1967), pelo qual, por meio da análise de erros a posteriori, e não mais como predição, trata-se de identificar diversas origens para os desvios, além de validar a hipótese da transferência.

Com o aparecimento da AE, a AC perde fôlego, passando a ser criticada por considerar a transferência como única origem para os desvios. A partir da década de 1980, no entanto, há uma retomada do papel da transferência, dessa vez relacionando-a com outros fatores também presentes na aquisição de L2, como processos de marcação.

No Modelo de Ontogenia (MAJOR, 1987), por exemplo, é ressaltada a influência da L1 no início da aquisição de L2, período em que, de acordo com o modelo, há uma transferência elevada de características da L1, a qual decresce paulatinamente com o passar do tempo, conforme a aprendizagem avança. Para o autor, existem paralelos entre a L1 e a L2 no que concerne ao processo de aquisição da fonologia; por exemplo, existem estratégias de substituição de sons que são empregadas tanto pelo aprendiz de L1 quanto pelo aprendiz de L2. Major cita o estudo de Flege e Davidian ${ }^{6}$ (1984) em que os autores constatam que falantes nativos de chinês, espanhol e polonês, ao falarem inglês como L2, realizam processos de não vozeamento ou de apagamento de oclusiva em final de palavra, característica também

\footnotetext{
${ }^{6}$ FLEGE, J.; DAVIDIAN, R. Transfer and developmental processes in adult foreign language production. Journal of Applied Psycholinguistic Research, v. 5, p. 323-347, 1984.
} 
encontrada na fala de crianças ao adquirir o inglês como L1. Conforme o autor, esses processos de desenvolvimento presentes na fala dos aprendizes de L2 aumentam em detrimento dos processos de transferência, que diminuem. Mais tarde, no decorrer da aquisição, os processos de desenvolvimento passam também a diminuir. Na Figura 1.1, esses processos seguem esquematizados:

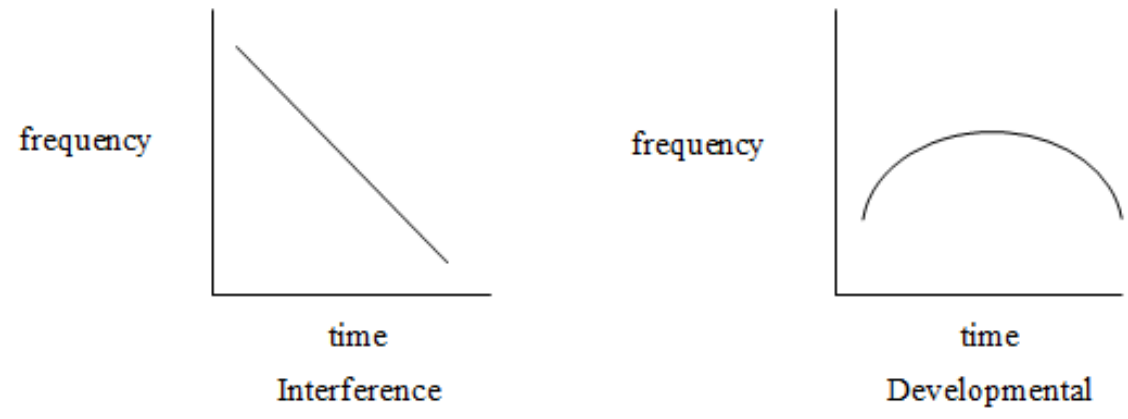

Figura 1.1 - Processos de transferência (interference) e desenvolvimento (developmental) de acordo com o tempo de aprendizagem (MAJOR, 1987, p. 103)

A transferência da L1 na aquisição da fonologia de L2 também é demonstrada por estudos de percepção. Trubetzkoy (1969 [1939]) já comparava o sistema fonológico da L1 a uma peneira, na qual vogais e consoantes da L2 deveriam passar. Em um estudo de Michaels ${ }^{7}$ (1974 apud FLEGE, 2003, p. 4), constatou-se que russos aprendizes de inglês como L2 tendiam a substituir $/ \theta /$ por $/ \mathrm{t} /$ e aprendizes japoneses substituíam $/ \theta /$ por $/ \mathrm{s} /$, ainda que /t/ e /s/ fizessem parte do inventário fonológico dos dois idiomas, tanto do russo quanto do japonês. A hipótese de Michaels foi a de que a percepção dos russos da não-estridência de $/ \theta$ / os levaram a substituir o segmento do inglês pelo som russo não-estridente mais próximo, /t/, enquanto a percepção dos japoneses da continuidade de $/ \theta /$ fez com que eles substituíssem esse som pelo segmento contínuo mais próximo em japonês, /s/. Nota-se então que a importância dada a traços distintivos pode se diferenciar dependendo da percepção do aprendiz, a qual pode ser substancialmente influenciada pela sua L1.

Dentre os trabalhos de percepção em L2 que tratam da importância da transferência da L1 na aquisição da fonologia de L2 destacam-se o Modelo de Assimilação Perceptual (BEST, 1995; BEST; TYLER, 2007), em que os sons em L2 são discriminados pelo aprendiz, iniciante e monolíngue, segundo seu grau de semelhança com os sons da L1 - não são bem discriminados dois sons em L2 tidos como pertencentes a uma única categoria de sons da L1;

\footnotetext{
${ }^{7}$ MICHAELS, D. Some replacements and phonological systems. Linguistics, v. 126, p. 69-81, 1974.
} 
o Modelo de Aprendizagem da Fala (FLEGE, 1995), pelo qual se considera que a aquisição de itens lexicais em L2 pode levar à criação de novas categorias para os segmentos, estando a diferença da fala nativa para a fala não nativa mais fortemente associada à transferência de quantidade de conhecimento fonético prévio da L1 do que pela perda da plasticidade neural, conforme havia sido proposto anteriormente (SCOVEL, 1988); e o Magnetismo da Língua Nativa (KUHL, 2000), que estipula que os efeitos de transferência ocorram por conta da dificuldade em se separar funcionalmente os mapeamentos (categorias) da L1 e da L2.

\subsubsection{Processos de marcação na interlíngua}

Além da atuação da fonologia de L1 na fonologia de L2, seja na produção, seja na percepção, outro aspecto fundamental na interlíngua do aprendiz relaciona-se aos princípios universais de marcação (ECKMAN, 1987; MAJOR, 2001). O conceito de marcação pode explicar, pelo menos em parte, o fato de haver semelhanças na produção em L2 de aprendizes de L1 distintas e de aparecerem desvios que não decorrem nem da L1 nem da L2 do falante.

O termo marcação, introduzido por Trubetzkoy (1969 [1939]), originalmente se refere à relação entre elementos de uma mesma classe fonológica em dada língua: em um par de sons em oposição, um dos elementos possui uma marca que está ausente no outro. De acordo com Rice (2007, p. 79), o conceito de marcação implica, basicamente, que nem todos os elementos de um sistema fonológico possuem status equivalente. No entanto, para a autora, não há uma definição bem delimitada para o termo, que adquiriu vários contornos.

Rice (2007, p. 80) lista as definições mais comuns para os termos marcado e não marcado, subdividindo-as de acordo com critérios não fonológicos e fonológicos.

Segundo critérios não fonológicos, o marcado se caracterizaria, entre outros aspectos, por ser "menos natural”, “mais complexo”, “mais específico”, “menos comum”, “menos estável”, “com aparecimento em poucas gramáticas”, “de aquisição mais tardia”, “mais difícil de ser articulado”, “mais saliente perceptualmente”. Ao contrário, o não marcado seria "mais natural”, “mais simples”, “mais geral”, “mais comum”, “estável”, “com aparecimento em mais gramáticas”, “adquirido mais cedo”, “mais fácil de ser articulado”, “perceptualmente menos saliente”.

No que concerne a critérios fonológicos, entre outras características, estruturas marcadas seriam mais sujeitas à neutralização e ao desencadeamento de processos assimilatórios, assim como menos propensas a se constituírem como segmentos epentéticos ou a sofrerem apagamento. Em contrapartida, estruturas não marcadas apareceriam como 
resultado de neutralização, seriam alvo de processos assimilatórios e teriam maior tendência a se constituírem como elementos epentéticos e a sofrerem apagamento.

Para Archangeli (2003 [1997], p. 2), o ideal seria que um contínuo fosse estabelecido para a definição do conceito, o qual iria de propriedades “completamente não marcadas”, verificadas praticamente em todas as línguas, a propriedades "extremamente marcadas", raramente encontradas.

Finalmente, de Lacy (2006, p. 5) afirma que a oposição marcado/não marcado é de ordem relativa: um elemento é mais marcado ou menos marcado em relação a outro elemento. O autor afirma que podem ser encontradas na literatura hierarquias de marcação, como exemplo menciona que é praticamente consensual em fonologia o fato de que exista uma hierarquia de vozeamento de obstruintes, a qual tem as obstruintes vozeadas como mais marcadas do que as obstruintes não vozeadas (de LACY, 2006, p. 34).

Nesta dissertação, adotam-se as acepções para o termo marcação listadas por Rice (2007), considerando ainda que o conceito seja gradiente (ARCHANGELI, 2003 [1997]) e relativo (de LACY, 2006).

Na aquisição de L2, especialmente em seu início, constata-se uma preferência por estruturas não marcadas. A hipótese da existência de processos de marcação na interlíngua dos aprendizes foi originalmente designada Hipótese da Marcação Diferencial (ECKMAN, 1987), e renomeada mais tarde para Hipótese da Conformidade Estrutural (ECKMAN, 1991). Segundo essa hipótese, as estruturas divergentes entre L1 e L2 são mais difíceis de serem adquiridas, o que já havia sido proposto pelo modelo de AC, mas a essa dificuldade, Eckman adiciona o grau de marcação: pressupondo-se que não haja a nova estrutura na L1 do aprendiz, essa será adquirida sem dificuldade caso seja menos marcada do que sua contraparte na L1 do aprendiz, mas, se for uma estrutura mais marcada do que em sua L1, o aprendiz terá dificuldade em adquiri-la.

De acordo com Hancin-Bhatt (2008, p. 119), apesar de haver evidência empírica significativa sobre a atuação dos efeitos de transferência e de marcação na interlíngua do aprendiz, são poucas as teorias linguísticas que dão conta da interação entre esses processos e, especialmente, de sua interação no decorrer do tempo, o que limita o caráter preditivo das análises. Além disso, ainda segundo a autora (2008, p. 128), embora seja possível observar a interação desses efeitos em diferentes níveis da fonologia, existem poucas tentativas de agrupá-los sob uma única teoria de gramática da interlíngua, limitando sua relevância a apenas determinado nível fonológico. A autora menciona haver propostas de mapeamento de traço no nível segmental, as quais não se estendem a aspectos prosódicos. 
Como se verá adiante, a Teoria da Otimidade, por abranger propriedades universais de marcação, pressuposto fundamental no modelo para a escolha da forma de output, por apresentar propriedades específicas das línguas, a partir do conceito de restrições violáveis e, finalmente, por poder se ocupar de diferentes níveis fonológicos, constitui-se como importante ferramenta no aprofundamento dos estudos em interlíngua.

\subsection{TEORIA DA OTIMIDADE E AQUISIÇÃO DA FONOLOGIA DE L2}

\subsubsection{Teoria da Otimidade - pressupostos fundamentais}

A Teoria da Otimidade (TO), introduzida por Prince e Smolensky (1993) e McCarthy e Prince (1993), constitui-se como um modelo baseado em restrições universais, cujo ordenamento propicia a escolha da melhor forma de superfície para uma dada forma subjacente.

Apesar de assumir restrições de caráter universal, a TO diverge de modelos gerativistas tradicionais ao considerar que as restrições possam ser violadas. Nessa proposta, há lugar para a universalidade e para a variação: por serem universais, as restrições apontam para as semelhanças que existem entre as línguas e, por serem violáveis, apontam para a variação existente entre elas (ARCHANGELI, 1999, p. 533).

Restrições passíveis de violação se fazem conhecidas por meio de um ranqueamento ou hierarquia. A violação de restrições que estão em posição inferior na hierarquia é tolerada a fim de satisfazer restrições que estão em uma posição mais elevada. Como a posição das restrições na hierarquia pode variar de língua para língua, sua importância também varia de acordo com a língua, assim uma determinada restrição pode ter papel crucial em uma língua e irrelevante em outra.

A TO dispõe de um mecanismo que seleciona o melhor correspondente de superfície para uma determinada representação subjacente, o qual opera em um nível universal e em um nível particular.

No nível universal, segundo o modelo, existem:

a) um conjunto de restrições de representações fonológicas, denominado CON (constraints 'restrições'); 
b) um gerador de candidatos de representações de superfície (outputs) associados a uma representação mental/subjacente (input), denominado GEN (generator 'gerador');

c) um mecanismo, denominado EVAL (evaluator 'avaliador'), que avalia os potenciais outputs e, levando em consideração o ranqueamento de restrições de dada língua, seleciona o output ótimo para o input em questão.

Segundo o modelo, no nível particular, cada língua precisa identificar sua hierarquia de restrições, ou seja, seu ranqueamento de CON (ARCHANGELI, 2003 [1997], p. 13).

A Figura 1.2 resume o funcionamento da gramática proposto pela TO.

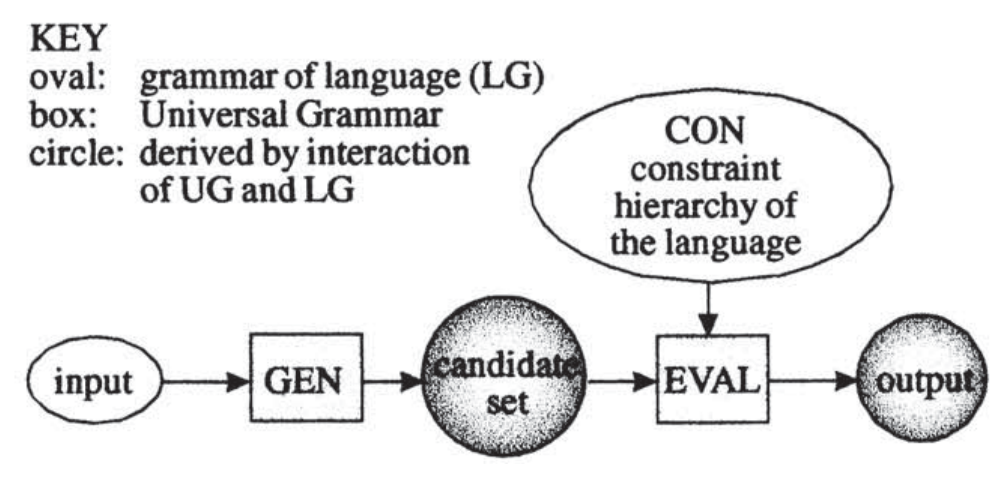

Figura 1.2 - Esquema de funcionamento da gramática proposto pela TO (ARCHANGELI, 1999, p. 534)

As informações da gramática de uma língua particular (input e CON) colocam-se em funcionamento com a Gramática Universal (GEN e EVAL). Para um dado input, GEN gera um conjunto de candidatos, os quais possuem correspondência entre seus elementos e os elementos do input. EVAL então seleciona o candidato ótimo para aquele input, utilizando-se da hierarquia de restrições daquela língua (CON), ou seja, seleciona o candidato mais harmônico, que melhor obedece a restrições de boa formação linguística segundo a hierarquia daquela língua. O candidato escolhido por EVAL emerge então na fala, caracterizando-se como output ótimo.

Nesse sistema, há duas grandes famílias de restrições: as de fidelidade e as de marcação. As restrições de fidelidade requerem que o input e o output sejam iguais, proibindo na fonologia de uma língua, apagamento, epêntese ou modificação de um traço, por exemplo. Já as restrições de marcação operam a favor de formas não marcadas, podem, por exemplo, militarem a favor da sequência onset + vogal em uma sílaba ou então proibirem coda silábica, 
indicando, nesse caso, uma preferência por um tipo de sílaba não marcado, constituído por consoante acompanhada de vogal (CV).

A classe de restrições de marcação entra em conflito com a classe de restrições de fidelidade pelo fato de a primeira requerer formas menos marcadas, mesmo que essas se distanciem da forma de input, e a segunda favorecer a correspondência entre input e output, ainda que isso resulte em um output seja mais marcado.

De forma sintética, a TO, em sua versão standard (MCCARTHY; PRINCE, 1993; PRINCE; SMOLENSKY, 1993), é então governada pelos seguintes princípios:

a) universalidade - as restrições estão presentes em todas as línguas, sendo, portanto, universais;

b) violabilidade - as restrições podem ser violadas, de acordo com a posição que ocupam na hierarquia de dada língua;

c) otimidade - um output é selecionado como ótimo quando incorre apenas em violação de restrições baixas na hierarquia, as quais não são cruciais no idioma, sendo, portanto, violadas;

d) dominação - em um par de restrições em conflito, a restrição ranqueada em posição superior possui prioridade em relação à restrição que a segue abaixo na hierarquia.

Tableaux são usados na aplicação do modelo de TO (Figura 1.3).

\begin{tabular}{|l||c|c|c|}
\hline & $\mathrm{C}_{1}$ & $\mathrm{C}_{2}$ & $\mathrm{C}_{3}$ \\
\hline \hline a. $\cos$ candidate $a$ & & $*$ & $*$ \\
\hline b. candidate $b$ & & $* * !$ & \\
\hline c. candidate c & $* !$ & & \\
\hline
\end{tabular}

Figura 1.3 - Exemplo de tableau (KAGER, 1999, p. 25)

Na linha superior, as restrições (C) são dispostas de acordo com a hierarquia da língua. Os candidatos a output estão na primeira coluna. O asterisco (*) marca uma violação em determinada restrição, a exclamação (!) indica que a violação é fatal, ou seja, por conta dessa violação, elimina-se o candidato, e o símbolo (®) aponta para o output ótimo, o qual deve emergir na fala. A área sombreada indica as restrições que não são mais relevantes para a escolha do candidato. 


\subsubsection{Aquisição da fonologia de L2 via Teoria da Otimidade}

De acordo com a literatura em aquisição de L2 que se utiliza da análise de dados via TO, a hierarquia de restrições da L1 e o conjunto de restrições universais de marcação interagem na interlíngua dos aprendizes. Considera-se, geralmente, que o estágio inicial de aquisição fonológica de L2 pelo falante adulto caracteriza-se pela mesma hierarquia de restrições de sua L1, sendo que, conforme a aquisição avança, ocorre um rerranqueamento de restrições de marcação e de fidelidade e uma aproximação gradual à hierarquia da L2 (BROSELOW et al., 1998; DAVIDSON et al., 2004; HANCIN-BHATT, 2008; PATER, 1997).

Um dos estudos mais conhecidos de aplicação da TO em aquisição de L2 é o de Broselow et al. (1998), em que foi analisada a produção de obstruintes em coda por falantes nativos de mandarim aprendizes de inglês. Os dados dos informantes caracterizavam-se pela simplificação de formas, ora pela opção por sílabas CV, por meio de epêntese ou apagamento, p. ex. [vıg] pronunciado [vı.gə] ou [vı], ora pelo não vozeamento da obstruinte final, p. ex. [vıg] pronunciado [vık]. De acordo com as autoras, tais fenômenos não poderiam ser motivados nem pela L1 nem pela L2 do falante. Não há no mandarim evidência de uma regra de epêntese ou apagamento, assim como não há em inglês regra regular e produtiva de epêntese de vogal ou de apagamento de coda. Além disso, o desvozeamento final não é uma regra do mandarim, já que nem obstruintes surdas nem sonoras são permitidas em coda; também não é uma regra fonológica do inglês. Uma vez que os aprendizes não foram expostos a desvozeamento, epêntese ou apagamento, julgam as autoras que esses processos resultariam de restrições de marcação universais que estariam presentes em todas as gramáticas, mas que seriam mascaradas na gramática de L1 por efeitos de restrições de ranqueamento mais altas, eventualmente emergindo na $\mathrm{L} 2$.

Broselow et al. (1998) então defendem que a TO pode explicar o fato de uma estrutura menos marcada, ausente na L1 e na L2 do falante, poder emergir na interlíngua, sem que, para isso, seja necessário o uso de regras ou condições voltadas especificamente à aquisição de L2. Por meio de uma abordagem otimalista simples, voltada à formalização do ranqueamento de restrições de marcação e fidelidade, seria possível explicar aspectos da gramática da interlíngua, como a emergência do não marcado, exemplificada pelo estudo das autoras acima referido.

Segundo Hancin-Bhatt (2008, p. 129), tem aumentado o interesse na utilização da TO como modelo de análise para a compreensão de fenômenos de interlíngua. A própria autora 
foi uma das pioneiras na análise de dados de L2 via TO, com estudo sobre a interação da transferência de L1 e de efeitos de desenvolvimento na produção da sílaba em L2.

Hancin-Bhatt e Bhatt (1997) pesquisaram a produção de codas e onsets complexos do inglês como L2 por falantes nativos de espanhol e japonês, em nível intermediário de aprendizagem do idioma, apontando de que forma a frequência e os tipos de erros resultariam de fenômenos de transferência e de desenvolvimento.

No espanhol e no japonês não são permitidas codas complexas em posição final de palavra, apenas um número limitado de codas simples é permitido nessa posição, a saber: /n, l, r, s, d/ no espanhol, e /N/ no japonês. Em contrapartida, em inglês, além de praticamente qualquer segmento poder vir em coda simples - exceto /h/ (HAMMOND, 1999) -, há também a possibilidade de haver diversas sequências em coda complexa. As líquidas /l, r/ podem ser acompanhadas em coda por segmento oclusivo, fricativo ou nasal.

Ambos os grupos de informantes do estudo de Hancin-Bhatt e Bhatt (1997), falantes de espanhol como L1 e de japonês como L1, simplificaram a coda complexa do inglês como L2 por apagamento, de maneira que, quanto menor fosse a diferença de sonoridade entre os dois segmentos ${ }^{8}$, maior seria a tendência ao erro ou simplificação. Para isso foi utilizada uma restrição sobre a distância mínima de sonoridade que consoantes em uma mesma posição silábica, por exemplo, em coda, deveriam ter.

A análise pôde então dar conta, via TO, de efeitos de licenciamento de segmentos na sílaba. No entanto, os dois grupos de informantes do estudo se diferenciaram quanto ao segmento da coda complexa (=cluster) que foi apagado. Os falantes nativos de espanhol tenderam a apagar o segundo elemento do cluster, mantendo a líquida, já os de japonês, tenderam a apagar o primeiro elemento, mantendo a obstruinte. Tais aspectos adviriam da transferência de efeitos de licenciamento da L1 para a L2, podendo ser também captados por uma restrição específica. Assim, seria possível identificar, por meio de um único modelo gramatical, a razão pela qual os aprendizes têm dificuldade com determinadas estruturas silábicas da L2 e a maneira pela qual eles as resolvem.

Sobre o inglês como L2 falado por aprendizes brasileiros, cuja análise é realizada por meio do modelo proposto pela TO, ressaltam-se os estudos de Monahan (2001) e Alves (2008).

Monahan (2001) mostra como a assimilação regressiva de nasalidade, a não realização de oclusivas nasais em coda e a semivocalização da lateral /l/, processos que ocorrem no

\footnotetext{
${ }^{8}$ Da maior distância de sonoridade entre os segmentos do cluster para a menor, tem-se: líquida + oclusiva < líquida + fricativa $<$ líquida + nasal.
} 
português como L1 e que podem ocorrer no inglês como L2 por falantes brasileiros, podem ser explicados, via TO, pela transferência da hierarquia de restrições referentes à estrutura silábica do português para a interlíngua.

O trabalho de Alves (2008) também trata da aquisição da estrutura silábica do inglês por aprendizes brasileiros. O autor analisa a aquisição das sequências finais de obstruintes do inglês como L2 por falantes do sul do Brasil, desenvolvendo sua análise via TO com base no Algoritmo de Aprendizagem Gradual (BOERSMA; HAYES, 2001).

Na TO, a representação de cada etapa da aprendizagem de L2, ou seja, da restruturação da gramática do aprendiz no decorrer do processo de aprendizagem, deve ser expresso por meio de algoritmos de aprendizagem. Baseando-se na percepção de outputs, a tarefa do aprendiz seria a de construir o ranqueamento de restrições da língua que está aprendendo, o que ocorreria pela função de um algoritmo.

Inicialmente formulados para a análise de dados em aquisição de L1, os dois algoritmos mais comumente utilizados na análise de dados de aquisição, sob o modelo da TO, são o Algoritmo de Demoção de Restrições (Constraint Demotion Algorithm - CDA), formulado por Tesar e Smolensky (1996, 2000), e o Algoritmo de Aprendizagem Gradual (Gradual Learning Algorithm - GLA), formulado por Boersma (1997) e por Boersma e Hayes (2001). Ao comparar as violações na forma ótima (winner, 'ganhadora') com as violações nas demais formas (losers, 'perdedoras’), a gramática do aprendiz estabelece quais restrições devem ser demovidas, ou seja, rerranqueadas mais abaixo na hierarquia. A demoção leva a uma nova hierarquia e a um consequente novo estágio de aprendizagem da língua.

No que concerne à análise da produção em PL2 que se utiliza de algoritmos de aprendizagem, cita-se a dissertação de mestrado de Quintanilha (2011), que trata da análise das ocorrências de oclusivas em coda medial de palavra - contexto sujeito à epêntese em PB por aprendizes hispanofalantes.

O grau de força das restrições nos diferentes estágios pelos quais passam os aprendizes não será tratado aqui, onde se propõe estabelecer ranqueamentos iniciais. Espera-se, no entanto, que este trabalho, ao estabelecer as hierarquias iniciais referentes a processos fonético-fonológicos até então não analisados na produção em PL2 por anglófonos, possa servir como ponto de partida para análises que levem em conta as diversas etapas desenvolvimentais de aprendizagem desses processos. 


\subsection{VOZEAMENTO E NASALIDADE EM CODA EM PB E INGLÊS}

Esta seção trata do vozeamento de obstruintes em coda e do status de segmentos nasais, tanto para o inglês como para o PB. Duas teorias serão utilizadas na abordagem dos fenômenos: a teoria métrica da sílaba (SELKIRK, 1982), por lidar com o licenciamento de constituintes silábicos em onset e coda, e a teoria da Geometria de Traços (CLEMENTS; HUME, 1995), por lidar com autossegmentos e espraiamento de traços. Aspectos das duas teorias relacionados aos processos aqui analisados serão tratados no decorrer deste trabalho.

\subsubsection{Status do vozeamento de obstruintes em coda silábica}

O padrão fonológico de assimilação de vozeamento ocorre quando o traço de sonoridade de um segmento é espraiado para o segmento que se lhe antecede, caracterizando um tipo de assimilação regressiva de vozeamento (ARV), ou que se the sucede, o que caracteriza um tipo de assimilação progressiva de vozeamento (APV). A sequência /sm/ da palavra 'mesmo', em português, passa por ARV: /m/ espraia seu traço de sonoridade para /s/, ['mez.mo]. Em inglês, assume-se que a forma subjacente para o plural seja /z/, assim cats 'gatos' passa por um tipo de APV, em que /t/ espraia seu traço de sonoridade para /z/: [kæts].

O tipo ARV é muito comum nas línguas do mundo, ocorrendo, por exemplo, em catalão, holandês, polonês, russo, sânscrito, além do português e, com algumas especificidades a serem apresentadas nesta parte, do inglês. Já o tipo APV é mais incomum, não ocorre em português, por exemplo, mas faz parte do sistema linguístico do inglês.

Nesta parte serão descritos o status de sonoridade de obstruintes em coda para ambos os idiomas, português e inglês, assim como os processos assimilatórios de vozeamento a que os dois idiomas estão sujeitos.

\subsubsection{Neutralização e assimilação de vozeamento em PB}

Em PB, em posição final de sílaba, a fricativa coronal /s/ passa por um processo de assimilação do traço de vozeamento, que é, por sua vez, regressivo (ARV). Esse processo fonológico ocorre tanto em posição interna de palavra quanto em posição de fronteira de palavra. Em posição que antecede pausa, permanece o não vozeamento (BISOL, 2005; CAGLIARI, 2007; MATTOSO CÂMARA JR., 2007 [1970]). 
Segundo Tenani (2002), em PB, o vozeamento da fricativa em final de sílaba diante de segmento sonoro, seja consonantal, seja vocálico, ocorre categoricamente, não se restringindo a nenhum domínio prosódico, a não ser o de pausa.

Vale ressaltar que, em determinadas regiões do Brasil, como em Porto Alegre e São Paulo, a fricativa coronal em coda é predominantemente realizada como as alveolares [s, z]; já em outras regiões do país, como em Recife e no Rio de Janeiro, as pós-alveolares, ou (pré-) palatais, [ $\left.\int, 3\right]$, são as realizações predominantes (CALLOU; MORAES; LEITE, 1994). Nas variantes em que $\left[\int, 3\right]$ são produzidas em coda silábica, os vocábulos 'festa', 'mesmo', 'mais tarde’ e 'mais verde', são realizados, respectivamente, como 'fe[C]ta', 'me[3]mo', 'mai[S] tarde' e 'mai[3] verde', à semelhança do português europeu. Em contexto que antecede vogal, no entanto, a fricativa é realizada como a alveolar [z] em ambas as variantes, palatais e não palatais, p. ex. 'mai[z] alto'.

Apesar de em PB, o processo de ARV envolver fricativas coronais finais alveolares e pós-alveolares, serão utilizadas como referência neste trabalho apenas as contrapartes alveolares da fricativa coronal, [s, z], por ser a cidade de São Paulo o ambiente de imersão dos informantes.

Abaixo, na Figura 1.4, segue esquematizado em forma de árvore da Geometria de Traços (CLEMENTS; HUME, 1995) o padrão de ARV em PB.

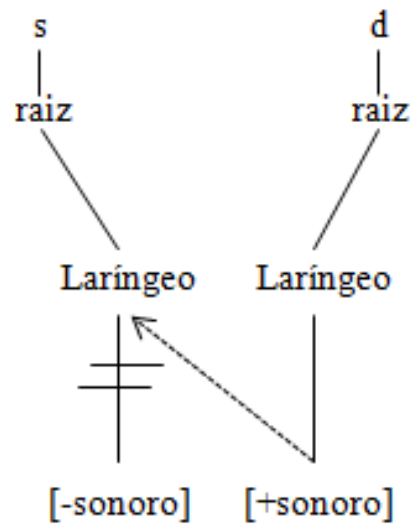

Figura 1.4 - Assimilação regressiva de vozeamento (PB)

Na representação arbórea acima, demonstra-se a assimilação do traço do nó laríngeo, o qual é responsável pelo status de vozeamento nas línguas. A oclusiva alveolar/d/ espraia seu traço [+sonoro] para a fricativa alveolar /s/ que se lhe antecede. A fricativa então deixa de possuir o traço [-sonoro], desligando-o, e adquire o traço [+sonoro] da obstruinte seguinte.

Assume-se, portanto, neste trabalho, que o fenômeno de ARV se trata de um processo de mudança de traços, e não de preenchimento de traços. Há processos fonológicos, como a 
“assimilação regressiva de desvozeamento”, que ocorre em inglês, por exemplo, que fazem referência ao traço [-sonoro], o que, segundo Wetzels e Mascaró (2001), demonstra o aspecto binário do traço de vozeamento, e não privativo, como defendem alguns estudiosos (cf. LOMBARDI, 1999).

Ademais, considera-se aqui a contraparte não vozeada da fricativa, /s/, como forma subjacente para a fricativa em coda no PB não apenas por [s] estar presente em mais contextos linguísticos (pausa e diante de segmento surdo, surgindo como [z] apenas diante de segmento sonoro), mas também por ser a primeira forma a emergir em dados de aquisição de L1 pela criança falante nativa de PB.

Em estudo de caráter naturalístico longitudinal com uma criança em processo de aquisição do PB como L1, no período de 1;8 anos até 4;0 anos, e de caráter experimental, com 46 crianças entre 2;0 e 4;1 anos, Silva (2008) identificou uma tendência das crianças em produzir fricativas surdas e evitar a produção de fricativas sonoras, sendo algumas das estratégias utilizadas o vozeamento incorreto (realização não vozeada da fricativa em coda diante de segmento sonoro), a metátese (transformação da coda medial sonora em coda final surda) e o apagamento da fricativa diante de segmento sonoro. Não houve, por nenhuma das crianças analisadas em seu estudo, um padrão de vozeamento da fricativa diante de consoante surda. Entende-se que dados de aquisição de L1 podem servir como suporte para que se ateste o valor de formas subjacentes, e Silva (2008), a partir dos dados de fala das crianças, conclui que /s/, e não /z/, seria então a forma subjacente para a fricativa alveolar em coda no PB, conforme já apontado pela literatura tradicional (MATTOSO CÂMARA JR., 2007 [1970]).

Ainda de acordo com Silva (2008), até os quatro anos de idade, a criança falante nativa de PB não realiza o processo de ARV categoricamente. A autora constatou que crianças até essa idade ainda não produziam sistematicamente a contraparte vozeada da fricativa alveolar em posição de coda diante de segmento sonoro. Tal fato indica que esse não é um fenômeno de motivação puramente fonética, ou seja, que ocorre obrigatoriamente devido ao contato com o segmento sonoro seguinte, mas é de ordem fonológica em PB, que, portanto, necessita ser adquirido pelo falante nativo.

Conforme Myers (2010, p. 165), tem havido propostas de que o padrão fonológico de ARV decorra de uma motivação fonética no nível diacrônico: a sobreposição de gestos laríngeos faz com que os ouvintes identifiquem determinada obstruinte como concordando em vozeamento com a obstruinte seguinte. Esses falantes podem então generalizar esse aspecto e inferir que haja uma restrição impedindo que consoantes adjacentes tenham diferentes traços para vozeamento. O novo padrão pode se espalhar pela comunidade de fala, resultando em 
fonologização (HYMAN, 1976 apud MYERS, 2010, p. 165) ${ }^{9}$, ou seja, no estabelecimento de um padrão fonológico de distribuição de categorias, o qual, de fato, resultou de uma reinterpretação diacrônica para uma produção gradiente. Isso explicaria o padrão fonológico de ARV nas línguas, inclusive no PB.

O comportamento da assimilação de vozeamento em PB pode então ser resumido da seguinte forma:

i) A obstruinte fricativa /s/ em coda não é vozeada diante de segmento [-sonoro] (consoantes surdas) nem diante de pausa;

ii) A obstruinte fricativa /s/ em coda torna-se vozeada diante de segmento [+sonoro] (vogais e consoantes sonoras), por um processo de espraiamento do traço [+sonoro];

iii) A ocorrência de ARV é um processo fonológico em PB, adquirido pela criança falante nativa nos primeiros estágios de aquisição do idioma;

iv) A ocorrência de ARV em PB não é restrita a determinado domínio prosódico.

\subsubsection{Vozeamento irrestrito e “assimilação de desvozeamento” em inglês}

Em inglês, são observados os processos de assimilação progressiva de vozeamento (APV) (GIMSON; CRUTTENDEN, 2008; GUSSENHOVEN; JACOBS, 2005 [1998]) e de “assimilação regressiva de desvozeamento” (GIMSON; CRUTTENDEN, 2008; MYERS, 2010; ROCA; JOHNSON, 1999; SMITH, 1997).

É consensual entre gramáticos da língua inglesa o fato de que ocorra no idioma APV. Nesse processo, a fricativa alveolar / $\mathrm{z} /$ que representa morfemas de plural dos nomes, de $3^{\mathrm{a}}$ pessoa do verbo no presente do singular e de formas de genitivo realiza-se como: a) [s], seguindo consoante surda, caps [kæps], b) [z], seguindo consoante sonora ou vogal, needs [ni:dz], sees [si:z], e c) [Iz] ou [əz], quando o término da palavra é em sibilante, watches [wo:t $\left.\int \mathrm{Iz}\right]$.

Em contexto de fronteira de palavra, o processo de assimilação regressiva de vozeamento (ARV) em inglês é geralmente considerado restrito a fricativas e africadas diante de consoante surda (GIMSON; CRUTTENDEN, 2008; MYERS, 2010; ROCA; JOHNSON, 1999; SMITH, 1997).

De acordo com Roca e Johnson (1999), fricativas e africadas vozeadas finais, como em (1a) abaixo, tornam-se desvozeadas quando são seguidas por obstruintes não vozeadas,

\footnotetext{
${ }^{9}$ HYMAN, L. Phonologization. In: JUILLAND, A. (Ed.). Linguistic studies offered to Joseph Greenberg. Saratoga, CA: Anma Libri, 1976. v. 2, p. 407-418.
} 
como em (1b), passando então a compartilhar o traço [-sonoro] dessas obstruintes. Caso o segmento diante da fricativa ou africada seja vozeado, permanece o seu traço subjacente de sonoridade, [-sonoro] ou [+sonoro], como se pode verificar em (1c).

(1) a. lose 'perder'

/lu:z/

b. lose ten-nil 'perder de dez a zero'

[lu:s] ten-nil

c. lose eight-nil 'perder de oito a zero'

[lu:z] eight-nil

O inglês difere do PB do seguinte modo: a fricativa que possui o traço [-sonoro] em seu nível subjacente, como em (2a), permanecerá surda mesmo diante de um segmento [+sonoro], como em (2b). Esse contexto daria a fricativa como vozeada em português.

(2) a. loose 'solto, folgado'

/lu:s/

b. loose end 'ponta solta'

[lu:s] end

A observação de que em inglês haja apenas "assimilação regressiva de desvozeamento”, ou seja, que ocorra alteração de vozeamento do segmento em coda apenas se o segmento que se lhe sucede não for vozeado, como em (1b), é atestada para o padrão americano, General American (MYERS 2010; SMITH, 1997), para o padrão inglês, Received Pronunciation (GIMSON; CRUTTENDEN, 2008) e para o inglês de Yorkshire (WELLS, $1982)^{10}$.

Embora Gimson e Cruttenden (2008), Myers (2010) e Smith (1997) não afirmem que a assimilação do traço [-sonoro] do segmento seguinte pela fricativa seja um processo categórico em inglês, todos eles parecem concordar que a fricativa surda em final de palavra não assimila o traço [+sonoro] do segmento seguinte, ou seja, (1b) pode por vezes não ocorrer, mas (1c) e (2b) são predominantes no idioma. É essa ausência de assimilação regressiva do traço [+sonoro] o aspecto a ser estudado na interlíngua dos informantes desta pesquisa.

\footnotetext{
${ }^{10}$ No caso do inglês de Yorkshire, oclusivas finais vozeadas também se tornam desvozeadas diante de segmento não vozeado (WELLS, 1982), o que, segundo Gimson e Cruttenden (2008, p. 300), raramente ocorre, por exemplo, na variante Received Pronunciation do inglês.
} 
O contexto de interior de palavra não será analisado na produção dos informantes, mas cabe ressaltar aqui as considerações de Ewen e Hulst (2001) sobre o vozeamento nessa posição. De acordo com os autores (2001, p. 117), em inglês, as obstruintes em cluster devem concordar em vozeamento somente se ocorrerem em uma palavra monomorfêmica, (3a), ou em palavras que contenham certos tipos de afixo, como o sufixo plural (3b) (em que a fronteira é representada por + ). A concordância não seria encontrada em palavras compostas (3c) (em que a fronteira é representada por \#):

(3) a. Brigden tactile

b. dogs cats

c. matchbox textbook [brigdən]

[tæktail]

$\mathrm{DOG}+\mathrm{PL}$

$\mathrm{CAT}+\mathrm{PL}$

MATCH\#ВOX [mætjbpks]

TEXT\#ВOOK [tekstb $\mho k]$

\author{
'Brigden' \\ 'tátil, palpável’ \\ 'cães' \\ 'gatos' \\ 'caixa de fósforo' \\ 'livro de texto/de ensino'
}

A abordagem de Ewen e Hulst (2001) sobre o vozeamento das obstruintes do inglês não entra em conflito com as considerações estabelecidas pelos demais pesquisadores aqui apresentados no que concerne à ausência de ARV diante de segmento sonoro, uma vez que esses últimos trataram de aspectos do padrão de vozeamento da obstruinte final específicos à posição de fronteira de palavra. Assim, uma sequência de segmentos em fronteira de palavra (ou em fronteira de palavra composta, (3c)) em que, no nível subjacente, o primeiro elemento não é vozeado e o segundo é vozeado, irá manter seu status de sonoridade subjacente.

Para verificar se de fato a fricativa surda em inglês não sofre ARV diante de segmento sonoro em posição de fronteira de palavra, Myers (2010) realiza um teste fonético de produção de fricativas nesse contexto linguístico por falantes nativos de inglês americano. $\mathrm{O}$ autor conclui que o efeito acústico do segmento seguinte fica mesmo limitado ao desvozeamento: as fricativas sonoras são afetadas por uma obstruinte seguinte surda, tornando-se também surdas, mas fricativas surdas não são afetadas, pelo menos, de forma significativa, por uma obstruinte seguinte sonora.

O fenômeno de ARV é então de padrão assimétrico em inglês: uma obstruinte deve concordar em vozeamento com a obstruinte seguinte apenas se essa não for vozeada, caso seja vozeada, a fricativa mantém o seu traço de sonoridade subjacente. Ademais, o padrão de vozeamento em interior de palavra diferencia-se do padrão de vozeamento em fronteira de palavra. 
De acordo com Myers (2010, p. 163-164), a presença de ARV nem sempre é simétrica nas línguas, há idiomas em que a obstruinte sempre concorda em vozeamento com a obstruinte seguinte e outros em que existem padrões alternantes de concordância de vozeamento, a depender, por exemplo, da posição silábica ou prosódica em que o segmento se encontra. O inglês está então entre esses idiomas em que o padrão de vozeamento é assimétrico.

Abaixo segue o resumo do padrão assimilatório de vozeamento do inglês:

i) Há APV apenas da fricativa alveolar de morfemas de plural dos nomes, de $3^{\mathrm{a}}$ pessoa do verbo no presente do singular e de genitivo;

ii) Ocorre ARV em posição de interior de palavra monomorfêmica;

iii) Não há ARV em posição de fronteira de palavra quando o segundo elemento é [+sonoro];

iv) Há um processo de “assimilação regressiva de desvozeamento” em fronteira de palavra, em que o segundo elemento, sendo [-sonoro], espraia seu traço de sonoridade para a fricativa ou africada (incluindo oclusivas, para alguns dialetos, como o de Yorkshire) que se lhe antecede.

\subsubsection{Status da nasal em coda silábica}

Apresenta-se, nesta parte, o status dos segmentos nasais que ocupam a posição de coda silábica, tanto para o português como para o inglês. Os conceitos de vogal nasal, vogal nasalizada e arquifonema nasal /N/ são discutidos, bem como o processo de assimilação de ponto de articulação pelo qual passa as consoantes nasais em coda em ambos os idiomas.

\subsubsection{A vogal nasal e o arquifonema /N/ em PB}

Um dos aspectos mais estudados e mais controversos da fonologia do PB é o status da nasal em coda silábica. Em abordagens estruturalistas e gerativistas, assume-se, frequentemente, que haja assimilação pela vogal do traço de nasalidade da consoante a sua direita, podendo haver, segundo alguns autores, posterior apagamento dessa consoante, p. ex. ‘canto’ /kaNto/ ['kã.to]. Sob a perspectiva de estudos multilineares, a nasalização é realizada como o espraiamento do traço [nasal] de um autossegmento flutuante, que se liga ao núcleo ou ao onset da sílaba (MATEUS; d'ANDRADE, 2000, p. 130). As diferenças recaem também sobre a abordagem da vogal nasal como um único fonema ou como bifonemática. 
Vale ressaltar que se utiliza aqui o termo vogal nasal para designar a vogal com traço [nasal] que possui valor contrastivo com a vogal oral, p. ex. a primeira vogal de 'canto' e a de 'senda', que levam as duas palavras a contrastarem, respectivamente, com ‘cato' e 'seda'. Assim como a vogal oral, a vogal nasal pode ser encontrada em posição tônica (p. ex. 'vento' ['vẽ. to]), átona (p. ex. 'vendaval' [vẽ $\tilde{n}^{\mathrm{n}}$ da'vaw]), de interior de palavra (p. ex. 'cinto' ['sĩn .to]) e de final de palavra (p. ex. 'homem' ['o.mẽj] ['o.mẽ $\left.\tilde{n}^{\mathrm{n}}\right]$ ).

Mattoso Câmara Jr. (2007 [1970]) ressalta que é importante diferenciar vogais nasais de vogais nasalizadas. Enquanto a primeira vogal de 'canto’ possui valor distintivo, uma vez que leva a palavra a contrastar com 'cato', o mesmo não ocorre com a primeira vogal de

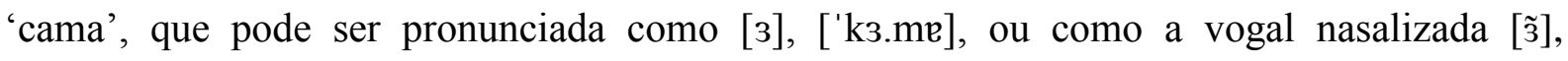
['kz̃.me], sem alteração de significado. Diferentemente das vogais nasais, as vogais nasalizadas não pertencem à mesma sílaba da consoante nasal, ou seja, precedem uma nasal heterossilábica, estando sujeitas à intensa variação regional: 'ama' ['3.me] ['3̃.me], 'amar' [3'mar] [з̃'mar] [a.mar]. Por seu caráter não contrastivo e, como consequência, por não se apresentar como característica que frequentemente afete a inteligibilidade da fala, a vogal nasalizada não será tratada neste trabalho.

A hipótese de que a vogal nasal seja caracterizada por uma sequência constituída por vogal oral $(\mathrm{V})$ e arquifonema nasal $(\mathrm{N})$, hipótese $V N$, é assumida por vários estudiosos, tanto do PB (BISOL, 2005, 2008; CAGLIARI, 2007; MATTOSO CÂMARA JR., 2007 [1970]) quanto do português europeu (MATEUS; d'ANDRADE, 2000). Segundo essa hipótese, a nasalidade da vogal decorre da consoante nasal seguinte, em posição de coda na sílaba.

Em uma perspectiva diacrônica, entende-se que as vogais nasais do português tenham resultado de vogais acompanhadas por consoantes nasais no latim. Essas consoantes poderiam estar a) em posição de coda silábica: lat. dente- > port. 'dente', lat. cambiare > port. 'cambiar', b) em posição intervocálica: lat. lana > port. 'lã', ou c) em posição final de palavra: lat. amant > port. 'amam', lat. cum > port. 'com'. O traço de nasalidade foi assumido pela vogal por um processo de assimilação regressiva (MATTOS e SILVA, 2006, p. 67).

A hipótese de que a consoante nasal do latim ainda exista na forma subjacente do português deve-se aos seguintes fatores, de acordo com Mattoso Câmara Jr. (2007 [1970], p. 59-60):

- não há degeminação da vogal nasal diante de vogal de início de palavra, p. ex. [lĩ a'zuw] 'lã azul', que se contrapõe à [ka.za'zuw] 'casa azul', indicando que existe um elemento entre a vogal nasal e a vogal oral seguinte; 
- não se verifica a presença do tepe [r] após a vogal nasal, p. ex. *hon[r]a, em vez disso, o rótico é realizado como $[\mathrm{x}]$ (ou $[\chi, \mathrm{h}, \mathrm{h}, \mathrm{R}]$ ) nessa posição, p. ex. 'hon[x]a'. Como o tepe não se realiza após sílabas fechadas por consoante, p. ex. *Is[r]ael, infere-se que, entre a vogal nasal e o rótico, esteja presente uma consoante, a nasal /N/, explicando o fato de apenas serem encontrados os segmentos $[\mathrm{x}, \chi, \mathrm{h}, \mathrm{h}, \mathrm{R}]$ nessa posição;

- não existe em interior de palavra hiato com vogal nasal. Nesse caso, a vogal perde a nasalidade, p. ex. 'bom’ vs. 'boa', ou o elemento consonântico nasal se move para a sílaba seguinte, p. ex. 'um’ vs. 'uma', comportando-se como outras consoantes em posição intervocálica que também se ligam à sílaba seguinte, p. ex. 'asa’, ‘ala’.

Assume-se, portanto, neste trabalho, que a vogal nasal seja formada em português, no nível subjacente, por uma sequência de vogal + consoante nasal /N/ e que, no nível de superfície, esse elemento nasal, por se constituir como um arquifonema, adquire diferentes formas a depender do contexto linguístico em que está inserido.

No PB, em interior de palavra, considera-se por diversos estudiosos, principalmente baseando-se em Mattoso Câmara Jr. (2007 [1970]), que o elemento nasal da sequência VN pode ter seu ponto de articulação condicionado pela consoante seguinte ou pela vogal precedente.

Caso a consoante seguinte à nasal seja uma oclusiva, a nasal assume o ponto de articulação dessa oclusiva, manifestando-se como bilabial (['põ $\left.{ }^{\mathrm{m}} . \mathrm{b} \mho\right]$ 'pombo'), alveolar (['mẽ. te] 'menta') ou velar (['pe $\left.\tilde{e}^{\mathrm{y}} . \mathrm{ke}\right]$ 'penca'), a depender do ponto de articulação da oclusiva seguinte (BISOL, 2005, 2008). Nesses contextos, Cagliari (2007, p. 95) acrescenta que pode ocorrer assimilação de ponto de articulação com a vogal precedente (['tõ̃ ${ }^{\eta}$.bv] 'tombo', ['fî̀ $\left.{ }^{\mathrm{n}} . \mathrm{kr}\right]$ 'finca') ou ainda realização da vogal sem a presença da consoante nasal (['tõ.bo] 'tombo', ['fî.ke] 'finca').

Se a consoante seguinte à nasal for uma fricativa, de acordo com Bisol (2005, 2008), a nasal pode assumir tanto o ponto de articulação dessa fricativa quanto o ponto de articulação da vogal anterior, p. ex. 'denso' ['dẽ ${ }^{\mathrm{n}}$.so], em que a nasal assume o traço alveolar da fricativa, e ['dên. sv], em que é assumido o traço palatal da vogal anterior ${ }^{11}$. Para Cagliari (2007, p. 95), no entanto, se a consoante seguinte for uma fricativa, não haverá compartilhamento de ponto de articulação. Nesse caso, ou a nasal não será manifestada, ou o compartilhamento de ponto de articulação será com a vogal que a precede: ['dẽ.so] ['d $\tilde{e}^{n}$. so] .

\footnotetext{
${ }^{11}$ Apesar de Bisol (2005) apontar que é possível a consoante nasal passar por ambos os tipos de assimilação diante de fricativa, progressiva ou regressiva, a autora, na análise via TO (2008), considera apenas a assimilação progressiva nesse contexto - /N/ assimila o ponto de articulação da vogal anterior.
} 
Cagliari (2007) então considera que também seja possível a realização apenas da vogal na sílaba, sem ser acompanhada por uma consoante nasal, o que ocorre diante de fricativa, mas que também pode ocorrer diante de oclusiva. Para Bisol (2005, 2008), no entanto, não existe nasalidade pura da vogal, haverá sempre um elemento consonântico representativo de $/ \mathrm{N} /$.

De acordo com Ferreira Netto (2001, p. 115), existe a possibilidade de que a assimilação progressiva, em que a consoante nasal assume o articulador ativo da vogal precedente (['põ $\left.\tilde{\eta}^{\eta} \cdot \mathrm{bv}\right]$ 'pombo', ['pe $\left.\tilde{\tilde{n}}^{\mathrm{n}} . \mathrm{t} \mathrm{r}\right]$ 'pente'), ocorra sob a forma de glide em alguns

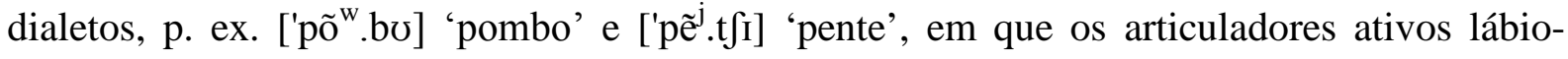

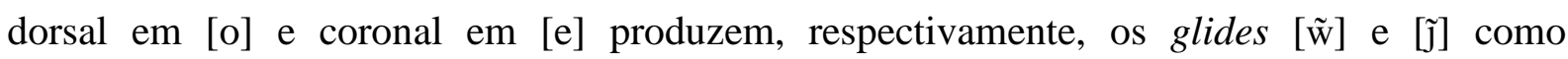
ressonância nasal. Ressalta-se que Bisol (2005, 2008) atenta para a realização do glide apenas em posição final de palavra, p. ex. 'homem' ['o.mẽn] ['o.mẽj], em que a consoante nasal alterna com o glide.

As considerações feitas pelos autores a respeito do status de /VN/ em coda interna de palavra seguem resumidas no Quadro 1.1 abaixo.

\begin{tabular}{|c|c|c|c|}
\hline Processo & Contexto & Exemplos & Autores \\
\hline \multirow[t]{2}{*}{$\begin{array}{l}\text { assimilação } \\
\text { regressiva }\end{array}$} & /VN/ + oclusiva & 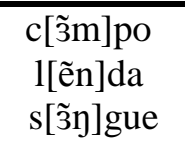 & $\begin{array}{c}\text { Bisol (2005, 2008), Cagliari } \\
\text { (2007), Mattoso Câmara Jr. } \\
\text { (2007 [1970]) }\end{array}$ \\
\hline & /VN/ + fricativa & $\mathrm{d}[\mathrm{ẽn}] \mathrm{so}$ & Bisol $(2005,2008)$ \\
\hline \multirow{3}{*}{$\begin{array}{l}\text { assimilação } \\
\text { progressiva }\end{array}$} & \multirow[t]{2}{*}{ /VN/ + oclusiva } & $\begin{array}{l}\mathrm{p}\left[\tilde{0}^{\mathfrak{n}}\right] \mathrm{bo} \\
\mathrm{c}\left[\tilde{3}^{\eta}\right] \mathrm{ta} \\
\mathrm{p}\left[\tilde{\mathrm{e}}^{\mathrm{n}}\right] \mathrm{te}\end{array}$ & $\begin{array}{c}\text { Cagliari (2007), Ferreira } \\
\text { Netto (2001), Mattoso } \\
\text { Câmara Jr. (2007 [1970]) }\end{array}$ \\
\hline & & $\begin{array}{l}\mathrm{p}\left[\tilde{\mathrm{o}}^{\mathrm{w}}\right] \mathrm{to} \\
\mathrm{p}\left[\tilde{\mathrm{e}}^{\mathrm{j}}\right] \mathrm{te}\end{array}$ & Ferreira Netto (2001) \\
\hline & /VN/ + fricativa & $\begin{array}{l}\text { [õy]ça } \\
\text { d[ẽn]so }\end{array}$ & $\begin{array}{c}\text { Bisol (2005, 2008), Cagliari } \\
\text { (2007) }\end{array}$ \\
\hline \multirow{2}{*}{ "vogal pura" } & /VN/ + oclusiva & $\begin{array}{l}\mathrm{t}[\tilde{o}] \mathrm{bo} \\
\mathrm{c}[\tilde{3}] \mathrm{ta} \\
\mathrm{f}[\tilde{1}] \mathrm{ca}\end{array}$ & Cagliari (2007) \\
\hline & /VN/ + fricativa & $\begin{array}{l}\tilde{1}] \text { feliz } \\
{[\tilde{o}] \text { ça }} \\
{[\tilde{e}] \text { che }}\end{array}$ & Cagliari (2007) \\
\hline
\end{tabular}

Quadro 1.1 - Manifestação de /VN/ em interior de palavra em PB 
No que concerne à posição final de palavra, segundo Ferreira Netto (2001, p. 114), há “claramente” na pronúncia paulistana a produção de um glide: [vẽj] 'vem', [bẽj] 'bem'. O autor acrescenta que a palatal [n] pode também ocorrer em posição final de palavra, mas desde que esteja após uma vogal palatal e em ambiente intervocálico: qu[ẽn] é 'quem é', n[ẽn] aquele ‘nem aquele' (FERREIRA NETTO, 2001, p. 85).

Cagliari (2007, p. 123) também faz referência à posição de fronteira de palavra. Quando uma nasal está em final de palavra e a palavra seguinte começa por uma oclusiva ou nasal, é comum, de acordo com o autor, que a nasal final de palavra se torne homorgânica à consoante do início da palavra seguinte: ‘lã bonita’ l[3̃m]bonita, 'vem depois’ v[ẽ̃̃n] depois, v[ẽ̃y] comer 'vem comer', ocorrendo, portanto, uma assimilação regressiva de ponto de articulação, tal como ocorre em interior de palavra quando a nasal está diante de uma oclusiva.

Cagliari (2007, p. 86) alerta que, no PB, é raro encontrar a realização de uma vogal monotongo nasalizada em final de palavra que não esteja acompanhada por uma consoante nasal ou por um glide, p. ex. [vẽ] 'vem', [bõ] 'bom', [ũ] 'um'. Nesse caso, é mais comum a produção de um monotongo + nasal, [vẽn], [bõy], [ũy]; de um ditongo nasalizado, [vẽj], [bõw̃], [ũ̃w]; ou de um ditongo nasalizado + nasal, [vẽ̃jn], [bõw̃y], [ũ̃̃y]. Em outros contextos, que não de final de palavra, essa última forma é às vezes utilizada para expressão de ênfase.

Ainda segundo Cagliari (2007, p. 120), em ambiente de fronteira diante de palavra iniciada por vogal o status de /N/ permanece o mesmo que o descrito acima, assim pode ocorrer, por exemplo, tanto uma sequência do tipo ‘[bõw̃y] amigo' quanto ‘[bõw̃] amigo' formas como *[bõn] amigo ou *[bõm] amigo não são atestadas.

Ressalta-se que, em ambiente de pausa, Cagliari (2007, p. 95) menciona que alguns falantes podem, às vezes, realizar uma nasal bilabial, mas apenas após uma vogal posterior fechada: [ũm] 'um', [xũm] 'rum'. De outro modo, não há realização de [m] ou [n] em posição final absoluta ou diante de segmento não homorgânico em ponto de articulação.

No Quadro 1.2, seguem resumidas as observações feitas pelos autores sobre o status da nasalidade em coda no PB em posição final e de fronteira de palavra. 


\begin{tabular}{|c|c|c|c|}
\hline Processo & Contexto & Exemplos & Autores \\
\hline $\begin{array}{l}\text { assimilação } \\
\text { regressiva }\end{array}$ & /VN/ + oclusiva & $\begin{array}{l}\mathrm{l}[\tilde{3} \mathrm{~m}] \text { bonita } \\
\mathrm{v}[\tilde{e} \tilde{\mathrm{e}}] \text { depois } \\
\mathrm{v}[\tilde{e} \tilde{y}] \text { comer } \\
\end{array}$ & Cagliari (2007) \\
\hline \multirow{4}{*}{$\begin{array}{l}\text { assimilação } \\
\text { progressiva }\end{array}$} & /VN/ + pausa & 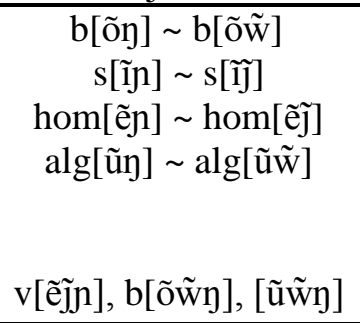 & $\begin{array}{c}\text { Bisol (2005, 2008), } \\
\text { Cagliari (2007), } \\
\text { Ferreira Netto (2001), } \\
\text { Mattoso Câmara (2007 } \\
\text { [1970]) } \\
\text { Cagliari (2007) }\end{array}$ \\
\hline & /uN/ + pausa & $\mathrm{r}[\mathrm{u} \mathrm{m}]$ & Cagliari (2007) \\
\hline & /VN/ + vogal & $\begin{array}{c}\mathrm{b}[\tilde{o} \tilde{w}] \text { amigo } \\
\mathrm{b}[\tilde{o} y] \text { amigo } \\
\mathrm{b}[\tilde{o} \tilde{w} y] \text { amigo }\end{array}$ & Cagliari (2007) \\
\hline & vogal palatal + /N/ + vogal & $\begin{array}{l}\text { n[ẽn] aquele } \\
\text { v[ז̃̃n] aqui }\end{array}$ & $\begin{array}{c}\text { Cagliari (2007), } \\
\text { Ferreira Netto (2001) }\end{array}$ \\
\hline
\end{tabular}

Quadro 1.2 - Manifestação de /VN/ em final e em fronteira de palavra em PB

Tendo feito a descrição do status da vogal nasal em PB, faz-se relevante explicar como se dá o processo de nasalização da vogal e de assimilação da consoante nasal. Para isso, utiliza-se aqui a abordagem não linear de Bisol (2008) e de Mateus d'Andrade (2000) para o fenômeno.

De acordo com Mateus e d'Andrade (2000, p. 130-132), em português europeu, o traço nasal é sempre mantido, por meio da realização da nasal como consoante e pelo espraiamento do traço para a vogal precedente, semelhante à abordagem adotada por Bisol para o PB $(2005,2008)$.

(5) a. nasal completamente especificada

b. nasal não-especificada

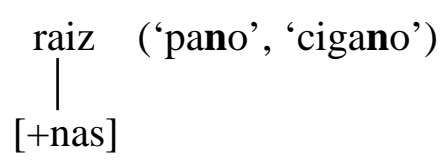
raiz > 0 ('pranto', 'ganso')

Nessa abordagem, a nasal caracteriza-se como uma coronal flutuante: a ausência de especificação para ponto de articulação faz com que surjam as diferentes formas de superfície descritas acima para a nasal, que apenas é licenciada em coda quando se associa à consoante seguinte ou à vogal antecedente (BISOL, 2008, p. 3-4). 


\subsubsection{As oclusivas nasais em coda final em inglês}

No inglês, ao contrário do português, não existem vogais nasais propriamente ditas. O que ocorre no idioma, de acordo com a literatura (EWEN; HULST, 2001; GIMSON; CRUTTENDEN, 2008; ROCA; JOHNSON, 1999), é a nasalização de vogais por ressonância nasal, a qual resulta do abaixamento regressivo, e também progressivo, do palato mole quando há uma consoante nasal adjacente (GIMSON; CRUTTENDEN, 2008, p. 299) semelhante ao que define as vogais nasalizadas do português. A nasalização das vogais do inglês não possui caráter contrastivo.

De acordo com Gimson e Cruttenden (2008, p. 299), podem ter ressonância nasal em inglês: a) vogais que precedem /m/ e /n/, como a vogal de ham 'presunto' e de man 'homem', b) vogais breves, tanto à direita quanto à esquerda da consoante nasal, como em sunny ‘ensolarado’ e singer 'cantor(a)', e, em menor grau, c) vogais após nasais, como em meal 'refeição' e now 'agora'. Formas como *[bĩ], apenas com uma vogal nasalizada sem consoante nasal adjacente, e *[bin], apenas com a consoante nasal sem nasalização da vogal, não ocorrem no idioma - a produção para bean 'grão', por exemplo, seria [bĩn].

Além da nasalização da vogal que antecede uma consoante nasal - e, em menor grau, que segue uma consoante nasal -, o inglês assemelha-se ao português quanto à possibilidade de mudança do ponto de articulação da consoante nasal em coda a depender do segmento seguinte. No entanto, de acordo com Ewen e Hulst (2001), esse processo em inglês é restrito a domínios específicos: a homorganicidade entre os dois elementos pode sempre ocorrer, nunca ocorrer ou ser opcional.

Segundo Ewen e Hulst (2001, p. 117), apenas em palavras monomorfêmicas, a nasal é obrigatoriamente homorgânica à oclusiva seguinte, como em ki[nd] kind 'tipo', em que [n] compartilha o ponto de articulação da oclusiva alveolar [d], e la[mp] lamp 'lâmpada’, em que [m] compartilha do traço bilabial da oclusiva [p] a sua direita. Caso a oclusiva final seja proveniente da realização de um sufixo de tempo passado, como em climbed 'escalou' e banged 'golpeou', não haverá assimilação de ponto, sendo os vocábulos produzidos como cli[md] e $b a[\mathrm{yd}]$ - a bilabial [m] e a velar [y] não se tornam alveolares em decorrência da consoante alveolar [d] seguinte.

Em palavras compostas, ainda de acordo com Ewen e Hulst (2001, p. 117), a assimilação de ponto é opcional quando se trata de uma nasal alveolar: moonbeam mu[nb]eam $\sim m u[\mathrm{mb}]$ eam, Sten gun ste[ng]un $\sim$ ste[ng]un. Quando se trata de uma nasal labial, [m], ou 
velar, [y], geralmente não há assimilação de ponto com a oclusiva seguinte: gumdrop gu[md]rop, gangbang ga[yb]ang ( $g u[\mathrm{nd}]$ rop e ga[mb]ang dificilmente ocorreriam).

Em fronteira de palavra, na fala concatenada, segundo Gimson e Cruttenden (2008, p. 301), também pode ocorrer assimilação da nasal alveolar com a oclusiva seguinte: ten people 'dez pessoas', ten days 'dez dias' e ten grapes 'dez uvas' podem ser produzidos, respectivamente, como te[mp]eople, te[nd]ays e te[yg]rapes ${ }^{12}$. Essa característica do inglês para a posição de fronteira de palavra também é mencionada por Gussenhovens e Jacobs (2005 [1998], p. 31), em que, por exemplo, a alveolar [n] da preposição in 'em’ assimila-se à oclusiva seguinte: $i[\mathrm{~m}]$ Paris, $i[\mathrm{y}]$ Copenhagen. Os autores não mencionam assimilação de $/ \mathrm{m} /$ subjacente com a oclusiva seguinte.

Em posição final de palavra diante de pausa, o contraste entre consoantes nasais geralmente é preservado na maioria dos dialetos do inglês, p. ex. as palavras wing 'asa', sung 'cantou', going 'indo', que terminam com a nasal velar [y], contrastam com win 'vencer', sun 'sol', gone 'foi', terminadas na nasal alveolar [n] (ROCA; JOHNSON, 1999, p. 65).

12 Em inglês, a nasal pode também se manifestar como a lábio-dental [m] pela influência de [f], p. ex. nymph ni[mf] 'ninfa', te[mf]orks 'dez garfos' (GIMSON; CRUTTENDEN, 2008, p. 297). 


\section{METODOLOGIA}

\subsection{INFORMANTES}

O corpus desta pesquisa é constituído por trechos de fala espontânea coletados em entrevistas com 11 aprendizes anglófonos de PL2, seis americanos e cinco britânicos, todos residentes na cidade de São Paulo no momento da coleta de dados, realizada em janeiro e fevereiro de 2011.

Para se obter acesso aos informantes, esta pesquisadora contatou escolas internacionais e instituições promotoras de programas de intercâmbio, além de amigos que conhecessem americanos e britânicos vivendo na cidade. Apenas um dos informantes desta pesquisa era conhecido da pesquisadora, no papel de seu ex-aluno.

O grupo de informantes contatado em escolas internacionais constituiu-se por três britânicos: uma professora de língua inglesa, o diretor da escola e um engenheiro, prestador de serviço na escola. As entrevistas foram realizadas em uma sala disponibilizada pela coordenadora.

Três informantes americanos foram entrevistados em uma instituição que oferece programas de intercâmbio a estrangeiros. Da mesma forma que com o grupo anterior, as entrevistas foram realizadas em uma das salas da instituição.

Os demais informantes desta pesquisa, dois britânicos e três americanos, foram entrevistados em seu local de trabalho, havendo, como nos demais casos, o cuidado de se buscar uma sala silenciosa, de modo que ruídos não interferissem na qualidade da gravação.

Temas como rotina, profissão, atividades de lazer e impressões sobre o Brasil e a língua portuguesa foram abordados durante as entrevistas, cujo objetivo principal, a análise da produção linguística dos informantes, apenas foi mencionado ao término das mesmas. De início, foi lhes dito que o objetivo era o da coleta de informações, para uma pesquisa de mestrado, sobre a vida de estrangeiros residentes no Brasil. Ao final das entrevistas, e já tendo tomado conhecimento de seu objetivo, todos os informantes aceitaram ter sua produção submetida à análise e se mostraram interessados com o andamento da pesquisa.

A heterogeneidade na escolha dos informantes desta pesquisa é proposital, uma vez que o objetivo volta-se à análise das semelhanças em sua produção em PL2. Dessa forma, serem falantes nativos de inglês que tivessem iniciado a aprendizagem de PL2 no Brasil e em idade adulta foi o único critério utilizado para a seleção dos informantes. 
Vale ressaltar que, apesar de as nacionalidades serem diferentes, americana e britânica, levantou-se a hipótese de que houvesse padrões em comum na realização de processos fonético-fonológicos entre os dois grupos de falantes, o que se constatou posteriormente.

No Quadro 2.1, seguem resumidos os detalhes sobre cada informante.

\begin{tabular}{c|c|c|c|c|c|c}
\hline Informante & Nacionalidade & Sexo & Idade & $\begin{array}{c}\text { Tempo no } \\
\text { Brasil }\end{array}$ & Profissão & $\begin{array}{c}\text { Outros } \\
\text { idiomas }\end{array}$ \\
\hline MAC & americana & $\mathrm{M}$ & 23 & 3 meses & estudante & espanhol \\
BET & americana & $\mathrm{F}$ & 21 & 3 meses & estudante & \\
JON & americana & $\mathrm{M}$ & 22 & 3 meses & estudante & \\
TYL & americana & $\mathrm{M}$ & 36 & 2 anos & administrador & espanhol \\
ELI & inglesa & $\mathrm{F}$ & 32 & 2 anos & professora & \\
TIM & inglesa & $\mathrm{M}$ & 41 & 3 anos & diretor financeiro & \\
JGR & inglesa & $\mathrm{M}$ & 45 & 9 anos & professor & espanhol \\
STE & inglesa & $\mathrm{M}$ & 40 & 10 anos & diretor de escola & \\
STA & americana & $\mathrm{F}$ & 42 & 11 anos & professora & \\
JMN & americana & $\mathrm{M}$ & 50 & 20 anos & tradutor & \\
PET & inglesa & $\mathrm{M}$ & 61 & 31 anos & engenheiro & \\
\hline
\end{tabular}

Quadro 2.1 - Informações sobre os informantes

\subsection{PROCEDIMENTOS}

Foi realizada uma sessão por informante, com duração entre 15 e 20 minutos, gravada com um aparelho da marca Zoom H4 Handy Recorder, a uma taxa de amostragem de 44,1 kHz. A segmentação das frases foi feita por meio do software Audacity.

Ocorrências de fricativas alveolares em coda final diante de palavra iniciada por segmento vozeado e de consoantes nasais em posição final de palavra foram extraídas do corpus e transcritas foneticamente por meio de uma análise de oitiva, totalizando 845 ocorrências: 411 ocorrências de /s/ e 434 ocorrências de /N/.

Os segmentos cujo estatuto de sonoridade se deu por incerto, o que representou 7\% dos casos, foram colocados à parte para que depois fosse realizada uma análise acústica por meio do programa Praat (BOERSMA; WEENINK, 2011), objetivando identificar-lhes o valor para o traço. Do mesmo modo, foram deixadas para análise acústica posterior, $4 \%$ das ocorrências de consoantes nasais em posição final de palavra. Finalmente, decidiu-se eliminar dos dados da pesquisa essas ocorrências que geraram incerteza quanto à transcrição auditiva, por não se constituírem em número expressivo e pelo fato de o objetivo aqui estar mais 
atrelado à interpretação do som pelo ouvinte, ao reconhecimento fonológico, do que a uma análise minuciosa de sua produção fonética.

Com o intuito de correlacionar fatores linguísticos e extralinguísticos que pudessem interferir nos resultados, fez-se uso do programa de análise estatística de dados linguísticos Goldvarb (SANKOFF et al., 2005), cujos resultados seguem descritos na próxima seção.

Após a descrição dos dados e da seleção de aspectos linguísticos e extralinguísticos relevantes, prosseguiu-se à análise via Teoria da Otimidade (TO) (MCCARTHY; PRINCE, 1995; PRINCE; SMOLENSKY, 1993), com o objetivo de se estabelecer a hierarquia de restrições da interlíngua do aprendiz no que concerne à produção (não) vozeada da fricativa diante de palavra iniciada por segmento sonoro e à produção de oclusivas nasais em posição final e de fronteira de palavra. 


\section{DESCRIÇÃO}

Neste capítulo, são apresentados os valores de frequência referentes à produção das contrapartes vozeada e não vozeada da fricativa alveolar final diante de segmento vozeado e à produção da nasal em posição final e de fronteira de palavra. São ainda verificados os fatores linguísticos e extralinguísticos que possam se correlacionar com a produção dos informantes.

\subsection{O (NÃO) VOZEAMENTO DA FRICATIVA ALVEOLAR EM POSIÇÃO DE FRONTEIRA DE PALAVRA NA INTERLÍNGUA DOS INFORMANTES}

Todos os 11 informantes desta pesquisa, em dado momento de sua fala, não realizaram a assimilação regressiva de vozeamento da fricativa alveolar diante de palavra iniciada por segmento vozeado (obstruinte vozeada, soante ou vogal). Dentre as 411 ocorrências de fricativa alveolar nessa posição, 243 (59\%) foram produzidas como [s] e 168 (41\%) como [z], havendo variação de caráter inter- e intra-individual.

Devido ao seu caráter variável, os dados foram submetidos ao programa de análise estatística de dados linguísticos Goldvarb (SANKOFF et al., 2005), dispondo-se detalhados nos subcapítulos que compõem esta seção.

Vale ressaltar que não houve casos de realização da fricativa alveolar vozeada diante de pausa ou de obstruinte não vozeada, o que tornou desnecessária a inclusão desses contextos na obtenção de fatores linguísticos e extralinguísticos relevantes. A alternância entre [s] e [z] foi encontrada apenas diante de segmentos vozeados.

\subsubsection{Fatores linguísticos}

Foram considerados os seguintes fatores linguísticos como potencialmente relevantes para a aplicação do vozeamento da fricativa alveolar /s/ em coda final diante de palavra iniciada por segmento sonoro:

1) contexto seguinte
a. vogal - /a, $\varepsilon, \mathrm{e}, \mathrm{i}, \mathrm{\jmath}, \mathrm{o}, \mathrm{u} /$
b. soante - /l, m, n/ 
c. consoante obstruinte sonora - /b, d, g, J, v, z, $3^{13}$

2) tonicidade da sílaba

a. átona - p. ex. 'todo/s/'

b. tônica - p. ex. 'atrá/s/'

3) característica morfêmica

a. raiz lexical - p. ex. 'ma/s/'

b. sufixo plural - p. ex. 'casa/s/'

Conforme visto anteriormente, em $\mathrm{PB}$, a fricativa /s/ em posição de coda adquire o traço [+sonoro] do segmento vozeado à sua direita, tornando-se vozeada, p. ex. 'o[z] mesmos’. Em inglês, em posição de fronteira de palavra, esse processo de assimilação regressiva do traço [+sonoro] não ocorre, p. ex. less is more le[s] is more 'menos é mais', em que a fricativa permanece surda.

Embora qualquer segmento vozeado do português possa espraiar seu vozeamento para a fricativa final que lhe antecede, por conta das diferenças de efeitos de assimilação desencadeados por vogais, soantes e obstruintes sonoras em outras línguas, resolveu-se elencar essas classes de segmentos em diferentes categorias do fator contexto seguinte, a saber: vogal, soante e consoante obstruinte sonora.

Por ser considerada uma língua natural, a interlíngua pode possuir características não presentes nem na L1 nem na L2 do falante, mas presentes em outras línguas naturais. Em inglês, segmentos vozeados, de modo geral, não espraiam seu traço de vozeamento para a obstruinte final antecedente, e, em português, todas as categorias de segmentos vozeados espraiam seu traço de vozeamento para a obstruinte fricativa antecedente. Há línguas que não possuem ARV da fricativa diante de soantes heterossilábicas, ocorrendo compartilhamento de traço apenas entre clusters de obstruintes. Em holandês, por exemplo, não há ARV desencadeada por soante de início de palavra prosódica, o segmento é desvozeado na forma de output e assim permanece diante de soantes, p. ex. die/v/+-achtig > die[f].achtig 'gatuno', podendo ser vozeado apenas diante de outra obstruinte, p. ex. za/k/+/d/oek $>$ za[g.d]oek 'lenço’ (GRIJZENHOUT, 2000, p. 5). Pode ser que na interlíngua dos informantes haja assimetria com relação ao tipo de segmento vozeado - vogal, soante ou obstruinte sonora -

\footnotetext{
${ }^{13} \mathrm{O}$ rótico não foi elencado em contexto seguinte, uma vez que há a possibilidade de que esse som esteja sendo realizado pelos informantes como a fricativa glotal [h] do inglês, som não vozeado e, portanto, não desencadeador do vozeamento da obstruinte antecedente. Também não foi considerado o fato de, em inglês, fricativas vozeadas em início de palavra sofrerem certo grau de desvozeamento, já que, entre sons vozeados, contexto relevante para a análise, essas fricativas tendem a ser vozeadas (ROACH, 1991, p. 48).
} 
que esteja espraiando o traço de vozeamento, tal como observado em outros sistemas linguísticos.

Além da relevância que o contexto seguinte pode assumir no que concerne ao vozeamento da obstruinte de final de palavra, a tonicidade da sílaba pode apresentar-se também como fator potencialmente relevante para a aplicação do vozeamento. Em posição tônica, os traços costumam ser preservados, desse modo, pode haver uma maior probabilidade de que em sílabas tônicas haja maior frequência da produção com [z], caso tenha sido essa a forma estabelecida como subjacente pelos informantes.

Presume-se aqui que a característica morfêmica da coda silábica, se lexical ou morfológica, possa ter correlação com o traço de vozeamento da fricativa alveolar produzida pelos informantes. Tal fato decorreria de um processo de transferência do inglês para a interlíngua.

Em inglês, conforme visto anteriormente, o sufixo $\{-z\}$ do genitivo, do plural de nomes e de verbos de $3^{\mathrm{a}}$ pessoa do singular do presente é pronunciado como [z] quando sucede segmentos sonoros, quer sejam consonantais, quer sejam vocálicos, p. ex. [ni:dz] needs 'precisa', [bedz] beds 'camas', [si:z] sees 'vê', [loz] laws 'leis'. À semelhança do que ocorre com o sufixo $\{-z\}$ do inglês pronunciado como $[z]$ após segmentos sonoros, postula-se que os informantes estariam mais propensos a realizar o sufixo plural do português também como [z], p. ex. 'mesas' *['me.zez], uma vez que o sufixo plural em português sucede segmento vocálico. A fricativa alveolar em coda morfológica de plural poderia então ter uma maior tendência a sofrer o processo de vozeamento do que a pertencente à coda lexical, essa última sem uma regra categórica de vozeamento em inglês, e, portanto, com menos possibilidade de transferência de padrões para a interlíngua dos falantes ${ }^{14}$.

A princípio, um quarto fator, posição na frase fonológica, tendo por subfatores interior de frase fonológica, p. ex. 'o/s/ guarda/s/ vieram', e final de frase fonológica, p. ex. 'ele/s/, apesar de atrasado/s/, estão aqui', havia sido incluso, por se constituir como fator potencialmente relevante para a aplicação de determinados processos fonético-fonológicos nas línguas, podendo assim atuar na interlíngua também. No entanto, pela discrepância entre o número total de ocorrências da fricativa alveolar final em contexto de interior de frase fonológica (325 ocorrências) e de final de frase fonológica (86 ocorrências, excluindo contextos diante de pausa), decidiu-se não incluir esse fator junto aos demais para a obtenção do peso relativo - para que o programa alcance resultados precisos, é necessário que a

\footnotetext{
${ }^{14}$ De acordo com Jones (1976), em inglês, há muitas exceções às regras sobre a terminação em /s/ ou /z/ em palavras lexicais, levando o falante nativo a adquirir a pronúncia de cada palavra isoladamente.
} 
distribuição de ocorrências por subfator seja equilibrada. Ademais, a posição na frase fonológica não é tida como relevante para a aplicação do vozeamento da fricativa alveolar em PB, a não ser diante de pausa, conforme estudo de Tenani (2002), e, em inglês, entende-se que o não vozeamento da obstruinte em fronteira de palavra diante de segmento sonoro tenda a ser preservado em interior e final de frase fonológica. Assim, optou-se por não incluir esse fator na análise.

\subsubsection{Fatores extralinguísticos}

Os seguintes fatores extralinguísticos foram submetidos ao programa Goldvarb para a obtenção de dados de frequência e peso relativo:

1) nacionalidade
a. americana
b. britânica

2) tempo de estudo formal de PL2
a. nenhum
b. menos de 6 meses
c. entre 2 a 3 anos

3) tempo de residência no país
a. 3 meses
b. 2-3 anos
c. 9-11 anos
d. 20-31 anos

4) conhecimento de espanhol
a. $\operatorname{sim}$
b. não

Apesar de não se conhecerem estudos sobre as variantes americanas e britânicas do inglês em que seja atestado um padrão fonológico de assimilação regressiva do traço [+sonoro] em fronteira de palavra, a não ser um tipo de “assimilação regressiva de desvozeamento", conforme apresentado anteriormente, resolveu-se utilizar a nacionalidade como um dos fatores extralinguísticos a serem incorporados na ánalise. No entanto, como se 
verá a seguir, esse fator não se correlacionou com a produção dos informantes. Ambos os grupos, americanos e britânicos, tiveram a mesma tendência ao (não) vozeamento da fricativa.

Como a pesquisa volta-se a dados de aquisição, o tempo de exposição ao idioma e o tempo de estudo formal de PL2 constituem-se como fatores cruciais para a análise, podendo determinar os resultados. Em estudos de aquisição de L2, geralmente, é possível encontrar correlação entre esses fatores e o desenvolvimento da interlíngua do aprendiz, motivo pelo qual foram aqui incluídos.

Quanto ao fator conhecimento de espanhol, ainda que apenas três pessoas desta pesquisa tenham admitido ter um nível intermediário de espanhol, optou-se em manter esse fator por considerá-lo influente na aplicação do não vozeamento. Em espanhol, não há distinção fonológica entre /s/ e /z/, as duas formas se neutralizam. Ainda que haja sonorização de /s/ em coda diante de obstruinte sonora, líquida e nasal - p. ex. no dialeto falado na cidade do México (HARRIS, 1969) - e, mais raramente, diante de vogal - p. ex. em alguns dialetos equatorianos (BRADLEY, 2005) -, essa sonorização costuma ser parcial e restrita a determinados contextos linguísticos, a depender do dialeto.

\subsubsection{Resultados}

Seguem descritos na Tabela 3.1, os dados referentes à frequência de aplicação da fricativa alveolar [z] pelos informantes, em posição de fronteira de palavra, considerando os fatores linguísticos contexto seguinte, tonicidade da sílaba e característica morfêmica e os fatores extralinguísticos nacionalidade, tempo de estudo formal de PL2, tempo de residência no Brasil e conhecimento de espanhol. Os fatores selecionados pelo programa Goldvarb como significativos, ou seja, que se correlacionam com a aplicação do vozeamento da fricativa alveolar, seguem na tabela com o seu valor para peso relativo.

Vale ressaltar que, em PB, assume-se que a fricativa alveolar em coda final diante de segmento sonoro seja sistematicamente realizada como [z], conforme visto anteriormente. Dessa forma, a aplicação do vozeamento em relação a cada um dos subfatores elencados seria de $100 \%$ de frequência por um falante nativo do idioma. 
Tabela 3.1 - Resultados de frequência e peso relativo para a aplicação de [z] pelos informantes em posição de fronteira de palavra em relação a fatores linguísticos e extralinguísticos

\begin{tabular}{ccccc}
\hline Fatores relevantes & Subfatores & $\mathbf{N}$ & $\mathbf{\%}$ & Peso relativo \\
\hline \multirow{2}{*}{ tempo de residência no } & 3 meses & $19 / 112$ & 16 & .22 \\
Brasil & $2-3$ anos & $29 / 110$ & 26 & .36 \\
& $9-11$ anos & $69 / 113$ & 61 & .72 \\
& $20-31$ anos & $51 / 76$ & 67 & .77 \\
\hline conhecimento de & não & $86 / 147$ & 58 & .39 \\
espanhol & sim $^{15}$ & $82 / 264$ & 31 & .68 \\
\hline \multirow{2}{*}{ característica morfêmica } & raiz lexical & $56 / 168$ & 33 & .40 \\
& sufixo plural & $112 / 243$ & 46 & .56 \\
\hline Fatores não relevantes & & & & \\
\hline \multirow{2}{*}{ contexto seguinte } & vogal & $110 / 244$ & 45 & - \\
& soante & $27 / 77$ & 35 & - \\
\hline \multirow{2}{*}{ tonicidade da sílaba } & obstruinte sonora & $31 / 90$ & 34 & - \\
& tônica & $61 / 171$ & 35 & - \\
& átona & $107 / 240$ & 44 & - \\
\hline \multirow{2}{*}{ nacionalidade } & americana & $83 / 219$ & 37 & - \\
& britânica & $85 / 192$ & 44 & - \\
\hline \multirow{2}{*}{ tempo de estudo formal } & nenhum & $69 / 113$ & 61 & - \\
de PL2 & menos de 6 meses & $73 / 222$ & 32 & - \\
& 2 a 3 anos & $24 / 73$ & 32 & - \\
\hline \multirow{2}{*}{} & & & & significância $=0.009$
\end{tabular}

Os fatores selecionados como significativos pelo programa Goldvarb para a aplicação da fricativa alveolar vozeada foram: tempo de residência no Brasil, conhecimento de espanhol e característica morfêmica, nessa ordem, conforme pode ser verificado na Tabela 3.1 quanto mais próximo a 1, mais favorável à produção vozeada. Os demais fatores, contexto seguinte, tonicidade da sílaba, nacionalidade e tempo de estudo formal de PL2, não se correlacionaram ao status de vozeamento da fricativa, sendo descartados pelo programa para a obtenção do peso relativo.

A começar pelo fator conhecimento de espanhol, nota-se que ter conhecimento básico ou intermediário desse idioma não fez com que os falantes tendessem ao não vozeamento da fricativa. Contrariamente ao esperado, os informantes que admitiram ter conhecimento de espanhol produziram mais frequentemente a contraparte vozeada $(p=.68)$ do que os demais informantes $(\mathrm{p}=.38)$. Provou-se, portanto, que o conhecimento desse idioma não favorece a produção surda da fricativa.

Quanto ao fator característica morfêmica, os resultados indicaram que a fricativa alveolar do sufixo plural foi mais frequentemente produzida como [z] do que a pertencente à

${ }^{15}$ Optou-se, para esta descrição, por acrescentar os dados dos informantes JMN e JON no subfator sim em conhecimento de espanhol, uma vez que esses informantes disseram ter algum conhecimento, ainda que básico, do idioma, por já terem convivido com hispanofalantes. 
raiz lexical, em um peso relativo de .56 contra .40 , o que, dentre os fatores selecionados como relevantes, caracteriza-se como o fator menos significativo. A diferença do peso relativo entre a coda morfológica de plural e a coda lexical não é tão alta se comparada à diferença do peso relativo dos subfatores das outras categorias selecionadas, não se estabelecendo uma correlação importante entre característica morfêmica e vozeamento de /s/, tal como se previa.

O fator que se mostrou verdadeiramente significativo para a produção da fricativa vozeada em final de palavra diante de segmento sonoro foi o tempo de residência no Brasil. Falantes residentes no país em um período superior a nove anos tenderam a produzir mais fricativas alveolares sonoras do que surdas. Em contrapartida, os falantes residentes no país até três anos produziram majoritariamente fricativas surdas nesse contexto. Nota-se que houve uma ordem crescente do peso relativo para a aplicação do processo: quanto maior o tempo de residência, maior a probabilidade de vozeamento.

Para a melhor compreensão do fator tempo de residência, resolveu-se dispor os valores a ele relacionados em gráficos (Gráficos 3.1).

Gráficos 3.1 - Número de ocorrências de [s] e [z] finais antecedendo segmento vozeado em relação ao tempo de residência no Brasil

$\square[s] \quad[z]$

a. 3 meses

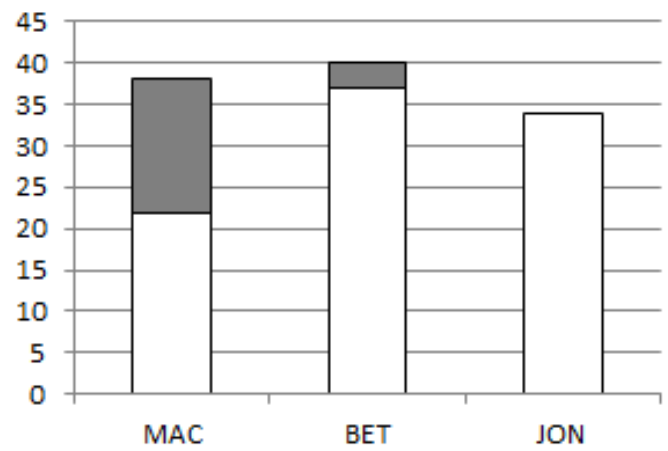

c. 9-11 anos

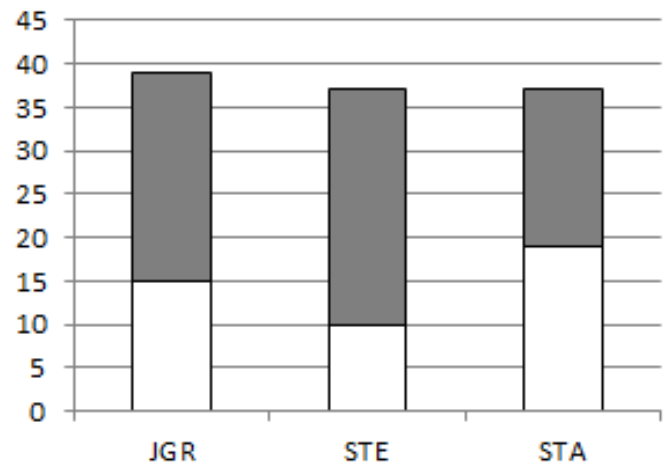

b. 2-3 anos

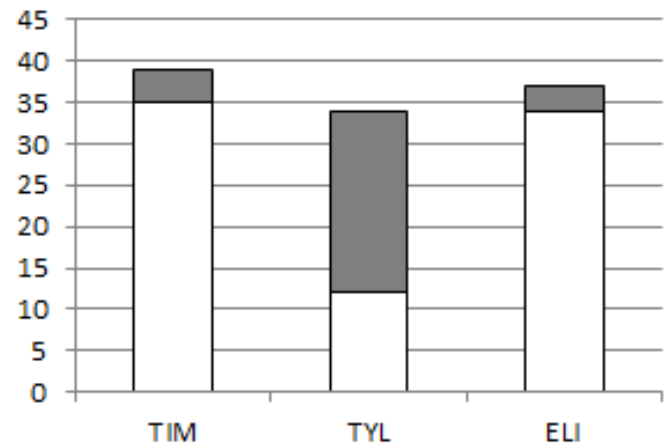

d. 20-31 anos

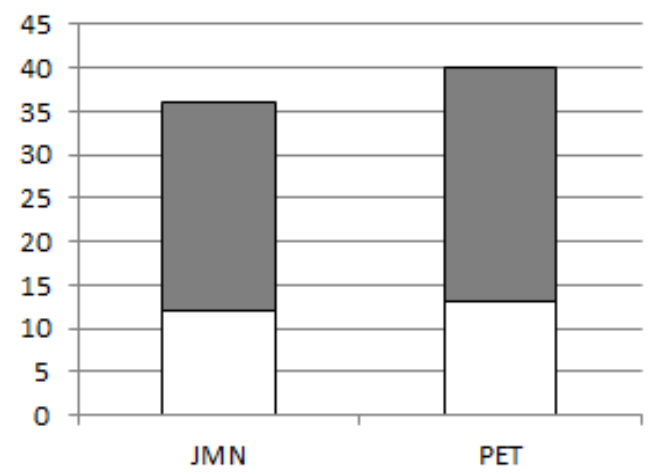


Conforme pode ser visualizado no conjunto de gráficos, há semelhança na produção dos dois grupos de falantes residentes no país até três anos (Gráficos 3.1a e 3.1b), assim como há semelhança entre os dois grupos de falantes residentes no país há mais de nove anos (Gráficos 3.1c e 3.1d) - com exceção de TYL, cujos dados de produção se assemelham aos falantes de maior tempo de residência.

Nota-se que é possível então separar os informantes em dois grupos: falantes residentes no país até três anos e falantes residentes no país há mais de nove anos, com a ressalva de que os resultados de produção de TYL aproximam-se mais dos resultados de falantes experientes.

A produção de [s] diante de segmento sonoro foi majoritária na fala dos aprendizes do primeiro grupo (residentes até três anos). Esse resultado parece indicar que esses falantes, de modo geral, baseiam-se nos padrões do inglês para o vozeamento. Em contrapartida, o grupo de falantes com maior tempo de residência (acima de nove anos) utilizou-se mais da contraparte vozeada da fricativa alveolar, aproximando-se da produção em L2.

\subsection{A PRODUÇÃO DA NASAL EM POSIÇÃO FINAL E DE FRONTEIRA DE PALAVRA NA INTERLÍNGUA DOS INFORMANTES}

Dentre os 11 informantes desta pesquisa, sete produziram, em algum momento de sua fala, a nasal alveolar ${ }^{16}$ [n] em posição final ou de fronteira de palavra, p. ex. 'si[n]', 'co[n] ele', e oito, a nasal bilabial [m], no mesmo contexto linguístico, p. ex. 'be[m]', 'també[m] todos’. Houve ocorrências de oclusivas nasais finais tanto diante de segmento consonantal não homorgânico, p. ex. 'te[m d]ois' - formado pelo cluster heterossilábico nasal bilabial + oclusiva alveolar -, quanto diante de segmento vocálico, p. ex. 'be[m a]gora'. Apenas um informante não produziu nenhuma das duas oclusivas nasais.

Conforme visto anteriormente, em português, as consoantes nasais [m, n] não ocorrem em posição final de palavra, a não ser diante de palavra iniciada por consoantes que lhes sejam homorgânicas em ponto de articulação ou, mais raramente, diante de pausa, após uma vogal posterior fechada, p. ex. 'ru[m]' (CAGLIARI, 2007). Ressalta-se que, na variante paulistana do $\mathrm{PB}$, /N/ em posição final de palavra tende a ser pronunciado como um glide nasalizado: [kõw] 'com', [bẽ̃] 'bem', [sĩj] 'sim', [aw'gũ̃u] 'algum’ (FERREIRA NETTO, 2001).

\footnotetext{
${ }^{16}$ Não são diferenciados, neste trabalho, segmentos oclusivos dentais de segmentos oclusivos alveolares.
} 
Na produção dos informantes, a ocorrência da bilabial [m], em posição final e de fronteira de palavra, foi bem mais produtiva do que a ocorrência da alveolar [n]: houve 89 ocorrências de [m] contra apenas 26 ocorrências de [n], em um total de 434 contextos relevantes - nos demais casos, /N/ assumiu outros tipos de realização, como se verá a seguir.

Possivelmente pela interferência da escrita - todos os informantes são letrados, com curso superior completo ou em andamento -, a produção de [m] tenha sido mais frequente que a produção de [n]. Palavras com término em <m> são comuns em português; em contrapartida, são poucas e incomuns as palavras terminadas em <n>, p. ex. 'hífen', 'cólon'. Ademais, a maior parte das produções em [n] pelos informantes ocorreu nas mesmas palavras, p. ex. 'e[n]', ‘co[n]', e pelos mesmos falantes, alguns deles tendo admitido conhecimento de espanhol (Quadro 3.1).

\begin{tabular}{ccc}
\hline Informante & $\begin{array}{c}\text { Conhecimento de } \\
\text { espanhol }\end{array}$ & Ocorrências \\
\hline MAC & sim & $\mathrm{co}[\mathrm{n}], \mathrm{e}[\mathrm{n}]$, també[n] \\
BET & não & $\mathrm{co[n],} \mathrm{e[n],} \mathrm{si[n]}$ \\
TYL & $\operatorname{sim}$ & $\mathrm{e}[\mathrm{n}]$ \\
JGR & $\operatorname{sim}$ & $\mathrm{e}[\mathrm{n}], \mathrm{co}[\mathrm{n}], \mathrm{usa}[\mathrm{n}]$, queria[n] \\
STE & não & $\mathrm{e}[\mathrm{n}]$ \\
JMN & $\operatorname{sim}^{17}$ & $\mathrm{e}[\mathrm{n}], \mathrm{co}[\mathrm{n}]$, fica[n], te[n] \\
PET & não & $\mathrm{co[n]}$ \\
\hline
\end{tabular}

Quadro 3.1 - Informantes que produziram vogal nasal + [n] em posição final de palavra

Por ter havido poucas ocorrências de [n] e por se considerar que sua produção esteja relacionada ao conhecimento de espanhol (pelo menos para os falantes MAC, TYL, JGR e JMN), optou-se por excluir esse segmento junto à análise de fatores linguísticos e extralinguísticos relevantes, uma vez que sua inclusão poderia acarretar falta de ortogonalidade nos dados. No entanto, a relevância da produção de [n] é retomada no capítulo de análise.

Supõe-se que a realização de qualquer uma das oclusivas nasais aqui tratadas, [m] ou [n], sirva como suporte para a produção da vogal nasal do português, o que pretende se esclarecer sob o modelo proposto pela TO.

É importante destacar que, neste trabalho, assume-se que as sequências <em>, <im>, <am>, <om>, <um>, em posição final de palavra, produzidas sem a articulação dos segmentos [m, n, j, w̃ ], mas ainda assim com a nasalização da vogal, p. ex. 'com' [kõ] e 'bom'

\footnotetext{
${ }^{17}$ Ressalta-se que o informante JMN relatou ter pouco conhecimento de espanhol (nível básico).
} 
[bõ], também ocupem sílabas travadas, tal como proposto por Mattoso Câmara Jr. (2007 [1970]) e Bisol (2005, 2008).

Para Bisol (2008), não há realização de vogal nasal sem uma consoante ou um glide à direita. Assim, admite-se, na produção dos informantes, que as vogais nasais não acompanhadas por [m, n, j, , w] possam estar diante de outro elemento consonântico, como a oclusiva velar [y], à semelhança de long /lo:y/ 'longo’ em inglês. No entanto, para simplificar a descrição e diferenciar essas vogais nasais das sequências vogal nasal $+[m, n, \tilde{j}, \tilde{w}]$, segmentos-alvo deste estudo, elas serão representadas apenas com o sinal gráfico do til.

Na Tabela 3.2, é apresentada a quantidade de ocorrências para a nasal bilabial [m], para a nasal alveolar [n] e para as demais ocorrências observadas: formas realizadas com um

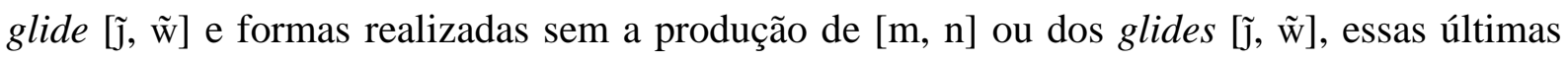
apresentadas na tabela simplesmente como vogal nasal.

Tabela 3.2 - Número e porcentagem de ocorrências das variáveis para a vogal nasal produzida pelos informantes em posição final e de fronteira de palavra

\begin{tabular}{|c|c|c|c|}
\hline Variável & $\mathbf{N}$ & $\%$ & Exemplos \\
\hline vogal nasal $+[\mathrm{m}]$ & 89 & 20,5 & $\mathrm{u}[\mathrm{m}]$ ano, gosta[m] do Rio, si[m] \\
\hline vogal nasal + [n] & 26 & 5,9 & e[n] espanhol, co[n] ela, si[n] \\
\hline $\operatorname{vogal}$ nasal $+[\tilde{\mathrm{j}}, \tilde{\mathrm{w}}]$ & 199 & 45,8 & $\mathrm{~b}[\tilde{\mathrm{e}} \mathrm{j}]$ antes, $\operatorname{gost}[\tilde{3} \tilde{\mathrm{w}}] \operatorname{sim}, \mathrm{b}[\tilde{\mathrm{o}} \tilde{\mathrm{w}}]$ \\
\hline vogal nasal & 120 & 27,6 & $\mathrm{c}[\tilde{\mathrm{o}}]$ isso, sabi $[\tilde{3}]$ muito, $[\tilde{\mathrm{u}}]$ \\
\hline
\end{tabular}

Na Tabela 3.2, verifica-se que a frequência da produção das oclusivas nasais [m, n] é relativamente baixa se comparada à produção da vogal nasal acompanhada pelo glide (199 ocorrências) ou da vogal nasal não acompanhada por nenhum desses elementos (120 ocorrências). No entanto, quando se considera a quantidade de informantes que produziram as oclusivas nasais [m, n] no contexto aqui analisado, foram dez informantes - com exceção de TIM -, lança-se a hipótese de que esse possa ser um aspecto significativo da interlíngua de aprendizes anglófonos de PL2, um dos quais a caracteriza como um sistema distinto do PB.

Questionados ao final das entrevistas sobre quais seriam os aspectos mais difíceis da língua portuguesa, dois informantes (BET e JON) afirmaram que as palavras com terminação em $<\mathrm{m}>$ lhes traziam grande dificuldade de pronúncia, citando 'com' e 'bem', como exemplos. Constata-se, portanto, que os informantes são conscientes de que a produção da sequência vogal nasal + /N/ em PB, em posição final de palavra, diferencia-se da produção em inglês, língua em que a realização de uma vogal com o traço [nasal] depende da realização de uma consoante nasal contígua. 
Cabe ressaltar que, apesar de ditongos nasais “verdadeiros” não terem sido analisados neste trabalho, foi também possível notar a inserção de [n] por alguns falantes em palavras com término em <ão>, p. ex. en[tz̃̃̃wn] 'então’ (JMN).

No conjunto de gráficos abaixo, consta o total de ocorrências de tentativas de produção das formas /eN/, /iN/, /oN/ e /uN/, por informante, para a posição final e de fronteira de palavra, em relação às variáveis vogal nasal + glide, vogal nasal $+[\mathrm{m}]$ e vogal nasal. Os informantes estão listados em ordem crescente de tempo de residência no país. As ocorrências de /aN/ serão tratadas separadamente.

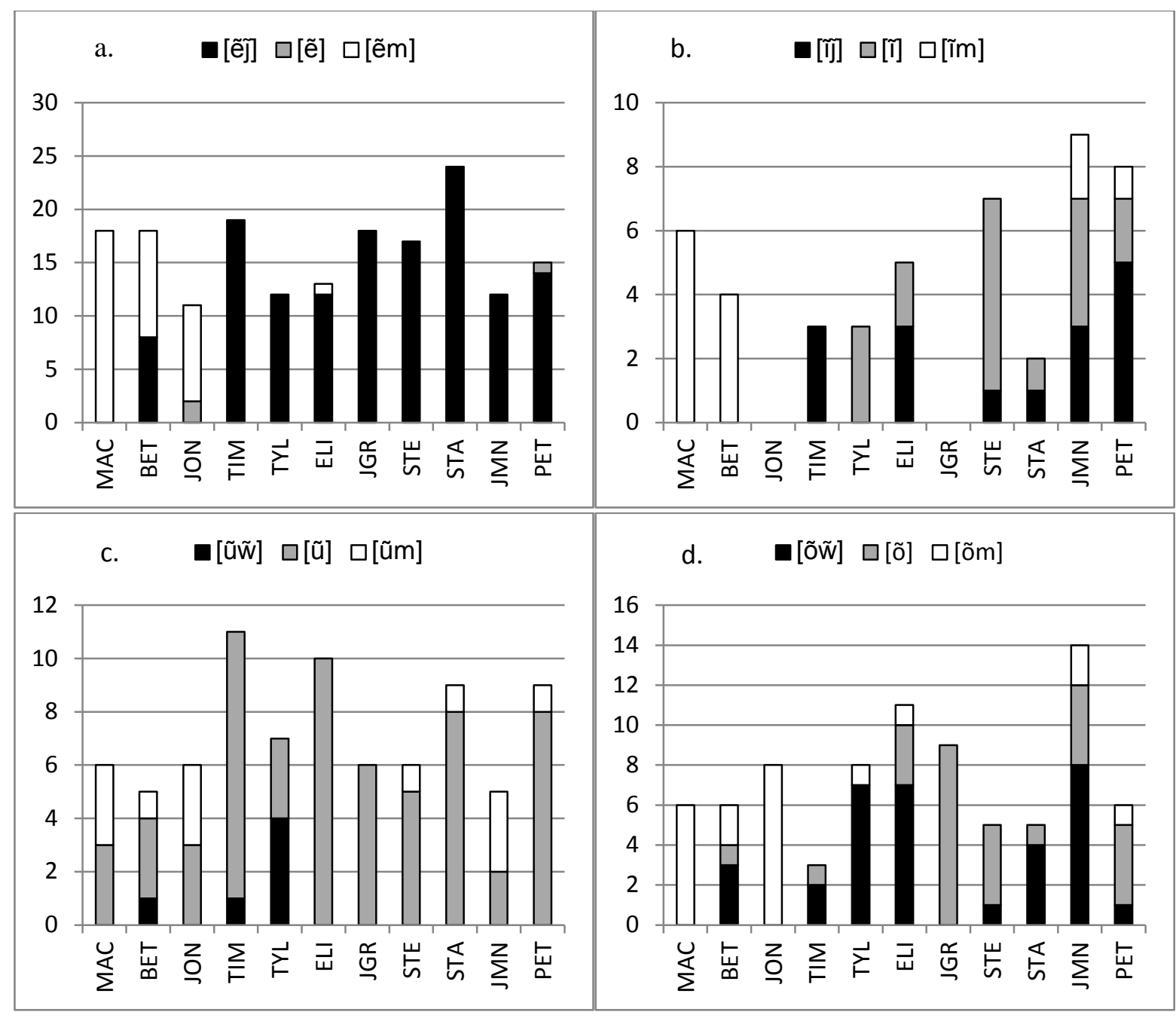

Gráficos 3.2 - Número de ocorrências (de tentativas) de realização de /eN/, /iN/, /oN/ e /uN/ por informante em posição final e de fronteira de palavra

Nos gráficos, nota-se que, tanto para as vogais anteriores quanto para as posteriores, os falantes iniciantes (MAC, BET e JON) são os que mais frequentemente produzem a oclusiva nasal [m], com alguns casos de realização do ditongo nasalizado por BET. Os demais falantes 
produzem [m] poucas vezes e comumente alternam entre a produção do glide e a produção apenas da vogal nasal, sem articulação de [m, n] ou de [j̃ , w]. Nota-se ainda que, para a sequência /eN/, o ditongo nasalizado é a forma predominante e, para /uN/, a forma predominante é a da vogal nasal sem oclusiva ou glide.

Por se tratar de dados de produção espontânea, não controlada, prevalecem algumas qualidades de vogais sobre as outras. A sequência /e/ + /N/, por exemplo, pode alcançar o dobro da frequência de /i/ + /N/. Ainda assim, foi possível estabelecer correlação entre a produção dos informantes e fatores linguísticos e extralinguísticos, com a ressalva de que o resultado para uma das sequências de vogais nasais, /aN/, por insuficiência no número de casos, mostrou-se inconclusivo (Gráfico 3.3).

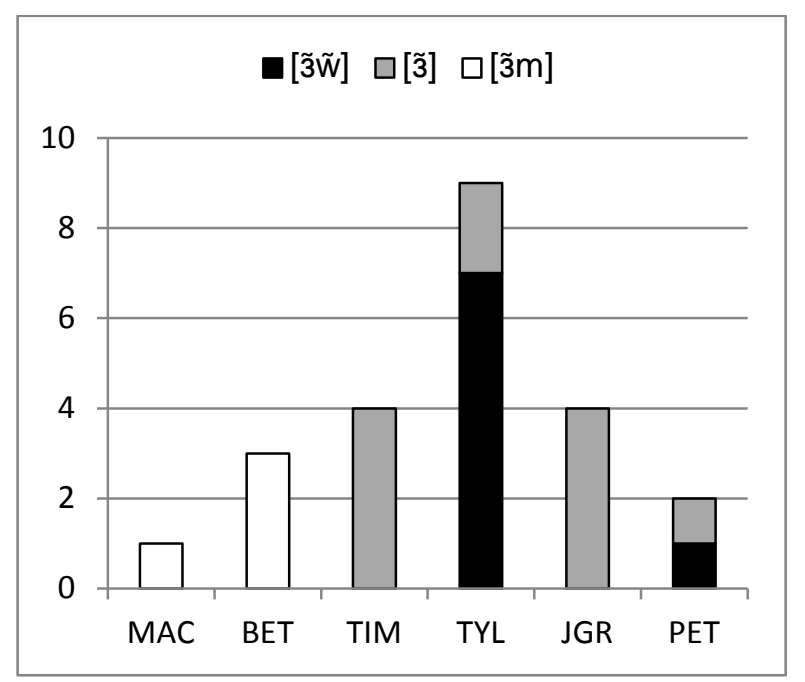

Gráfico 3.3 - Realização da sequência /aN/ por informante em posição final e de fronteira de palavra

O total de ocorrências de palavras com término em <am>, geralmente encontrada em verbos no plural, p. ex. falam e gostaram, foram insuficientes para o levantamento de hipóteses. Seria necessário um corpus mais robusto de análise para se afirmar, por exemplo,

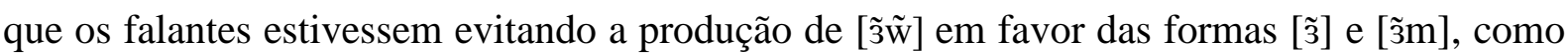
parece ocorrer nessa pequena quantidade de dados.

As partes seguintes desta seção ocupam-se da análise das ocorrências produzidas pelos informantes a partir de fatores linguísticos e extralinguísticos. 


\subsubsection{Fatores linguísticos}

Os fatores linguísticos que foram aqui considerados como potencialmente relevantes para a produção das variáveis de vogal nasal $+/ \mathrm{N} /$ (vogal nasal $+[\mathrm{m}]$, vogal nasal $+[\tilde{\mathrm{j}}, \tilde{\mathrm{w}}]$, vogal nasal) em posição final e de fronteira de palavra encontram-se listados abaixo:

1) qualidade da vogal ${ }^{18}$
a. /a/ - 'cantam'
b. /e/ - 'bem'
c. /i/ - 'jardim’
d. /o/ - 'som'
e. /u/ - 'algum'

2) contexto seguinte
a. pausa
b. vogal - /a, $\varepsilon, \mathrm{e}, \mathrm{i}, \mathrm{o}, \mathrm{o}, \mathrm{u} /$
d. oclusiva alveolar - /t, d, n/
e. oclusiva bilabial - /p, b, m/
f. oclusiva velar - /k, g/
g. fricativa - /f, v, s, z, $\int, 3, x, y, h, h /$

3) tonicidade da sílaba
a. átona - 'dizem’
b. tônica - 'também’

No PB, a qualidade da vogal e o contexto seguinte podem influenciar na produção da nasal em coda silábica, p. ex. 'bo[y]', 'si[j]]', em que [y] e [j] compartilham do ponto de articulação da vogal antecedente, e ‘ve[n] depois’ e ‘ve[y] comer', em que a nasal final tornase homorgânica ao ponto de articulação do segmento seguinte.

Em inglês, na fala concatenada, o contexto seguinte também pode induzir a processos de assimilação de ponto de articulação, p. ex. ten ‘dez’ em te[m] people ‘dez pessoas’ e te[y] grapes 'dez uvas', em que a nasal alveolar adequa-se ao ponto de articulação do segmento seguinte. No entanto, diferentemente do PB, ocorrem também em inglês clusters heterossilábicos não homorgânicos, p. ex. te[n] people, te[n] grapes, sem que haja assimilação

\footnotetext{
${ }^{18}$ Foram excluídas as vogais médias baixas / $/ \varepsilon /$ e / $/$, pelo fato de a nasalidade ser distintiva em PB no sistema de cinco vogais /a, e, i, o, u/ (BISOL, 2008; MATTOSO CÂMARA JR., 2007 [1970]).
} 
regressiva. Casos de assimilação progressiva, em que a nasal assimila o ponto de articulação da vogal precedente, não são conhecidos no idioma.

Com relação à tonicidade, entende-se que em posição de sílaba tônica, há uma maior tendência à preservação dos segmentos, o que pode se constituir em fator relevante para a análise. Postula-se, a princípio, que sílabas tônicas tenderão a ser pronunciadas com a consoante nasal ou com o glide com mais frequência do que sílabas átonas.

\subsubsection{Fatores extralinguísticos}

Com exceção de conhecimento de espanhol, foram utilizados aqui os mesmos fatores elencados como potencialmente relevantes para a aplicação do vozeamento da fricativa alveolar, a saber:

1) nacionalidade
a. americana
b. britânica

2) tempo de estudo formal de PL2
a. nenhum
b. menos de 6 meses
c. entre 2 a 3 anos

3) tempo de residência no país
a. 3 meses
b. 2-3 anos
c. 9-11 anos
d. 20-31 anos

Conhecimento de espanhol foi retirado porque sua possível interferência na interlíngua dos informantes estaria associada à produção de [n], e não de [m], esse último pouco produtivo em espanhol, p. ex. quórum, álbum. Os demais fatores extralinguísticos foram selecionados pelos motivos já expressos em 3.1.2, com relação à fricativa alveolar.

\subsubsection{Resultados}

Nesta parte, são primeiramente apresentados os valores para a presença vs. ausência da produção de [m] em coda, em seguida, considerando apenas os dados em que a nasal [m] não 
foi produzida, são apresentados os valores para vogal nasal + glide em contraste com os valores para a vogal nasal.

3.2.3.1 Produção da vogal nasal + oclusiva bilabial [m] em posição final e de fronteira de palavra

Na Tabela 3.3, são descritos os dados referentes à frequência de aplicação da variável vogal nasal $+[\mathrm{m}]$ em posição de coda final para os fatores linguísticos qualidade da vogal, contexto seguinte e tonicidade da sílaba e para os fatores extralinguísticos nacionalidade, tempo de estudo formal de PL2 e tempo de residência no Brasil. Os dois valores absolutos, representados por $\mathrm{N}$, referem-se, respectivamente, ao número de ocorrências de [m] para o subfator em questão e ao número total de contextos relevantes, ou seja, à soma dos casos de [m], de glide e de vogal nasal. Os valores percentuais referem-se à aplicação de [m] em relação às demais formas. Por último, os fatores selecionados pelo programa Goldvarb como significativos, ou seja, que se correlacionam com a realização de [m], seguem na tabela com os seus respectivos valores para peso relativo.

Tabela 3.3 - Resultados de frequência e peso relativo para a aplicação de vogal nasal + [m] pelos informantes em posição final e de fronteira de palavra em relação a fatores linguísticos e extralinguísticos

\begin{tabular}{|c|c|c|c|c|}
\hline Fatores relevantes & Subfatores & $\mathbf{N}$ & $\%$ & Peso relativo \\
\hline \multirow{4}{*}{$\begin{array}{c}\text { tempo de residência no } \\
\text { Brasil }\end{array}$} & 3 meses & $74 / 98$ & 75 & .97 \\
\hline & $2-3$ anos & 3/118 & 2 & .19 \\
\hline & $9-11$ anos & $2 / 112$ & 1 & .14 \\
\hline & 20-31 anos & $10 / 80$ & 12 & .59 \\
\hline \multirow{6}{*}{ contexto seguinte } & pausa & $25 / 91$ & 27 & .48 \\
\hline & vogal & $38 / 116$ & 32 & .70 \\
\hline & oclusiva alveolar & $11 / 46$ & 23 & .57 \\
\hline & oclusiva bilabial & $6 / 88$ & 6 & .20 \\
\hline & oclusiva velar & $4 / 23$ & 17 & .60 \\
\hline & fricativa & $5 / 44$ & 11 & .52 \\
\hline \multicolumn{5}{|l|}{ Fatores não relevantes } \\
\hline \multirow{5}{*}{ qualidade da vogal } & $/ \mathrm{e} /$ & $38 / 177$ & 21 & - \\
\hline & /i/ & $12 / 46$ & 26 & - \\
\hline & $/ \mathrm{u} /$ & $13 / 80$ & 16 & - \\
\hline & /o/ & $22 / 82$ & 26 & - \\
\hline & /a/ & $4 / 23$ & 17 & - \\
\hline \multirow{2}{*}{ tonicidade da sílaba } & tônica & $41 / 163$ & 25 & - \\
\hline & átona & $48 / 245$ & 19 & - \\
\hline \multirow{2}{*}{ nacionalidade } & americana & $83 / 217$ & 38 & - \\
\hline & britânica & $6 / 191$ & 3 & - \\
\hline \multirow{3}{*}{$\begin{array}{l}\text { tempo de estudo formal } \\
\text { de PL2 }\end{array}$} & nenhum & $11 / 120$ & 9 & - \\
\hline & menos de 6 meses & $77 / 209$ & 36 & - \\
\hline & 2 a 3 anos & $1 / 79$ & 1 & - \\
\hline
\end{tabular}


Conforme consta da tabela, apenas o fator extralinguístico tempo de residência no Brasil e o fator linguístico contexto seguinte foram selecionado pelo programa Goldvarb como relevantes.

Embora tempo de residência tenha sido selecionado como fator significativo para a aplicação da bilabial [m], assim como também se mostrou relevante para a aplicação do vozeamento da fricativa alveolar, diferentemente dos resultados para esse último processo, não houve uma relação diretamente proporcional entre tempo de residência e produção da bilabial [m]. O peso relativo para a produção da consoante nasal foi bastante elevado no primeiro grupo $(\mathrm{p}=.97)$, constituído por informantes residentes no Brasil há três meses, decrescendo bruscamente nos dois grupos seguintes, de falantes residentes no país entre dois e três anos $(\mathrm{p}=.19)$ e entre nove e onze anos $(\mathrm{p}=.14)$, e novamente elevando-se em falantes cujo tempo de residência ultrapassa 20 anos $(p=.59)$.

A produção da bilabial [m] está então fortemente correlacionada à fala de aprendizes anglófonos de PL2 no início de seu processo de aquisição do idioma e, embora haja decréscimo de sua realização conforme a aprendizagem avança, ainda ocorrem casos de produção da bilabial até mesmo nos dados de informantes cujo tempo de residência no país é superior a 20 anos.

Assim como a realização não vozeada da fricativa alveolar final diante de segmento sonoro, a produção da vogal nasal + /N/ permanece em variação na interlíngua dos aprendizes, com resultados que tendem a se aproximar da L2 na produção de aprendizes mais experientes. Propõe-se demonstrar que essa variação esteja vinculada à dificuldade de produção da vogal nasal, sendo a inclusão de [m, n] uma estratégia utilizada pelo aprendiz para facilitar essa produção.

De qualquer maneira, diferentemente da assimilação regressiva de vozeamento, a produção da vogal nasal, tal como realizada pelos falantes nativos de PB, tende a ocorrer com mais frequência na fala dos aprendizes e até a se estabilizar, como no caso do informante TIM, que não produziu nenhuma das oclusivas nasais [m, n] em posição de coda final, embora tenha realizado poucas vezes ditongos nasalizados, comuns na variante paulistana do PB.

O contexto seguinte foi o segundo fator selecionado como relevante pelo programa Goldvarb. A tendência para a produção de [m] foi relativamente equilibrada para os subfatores pausa $(\mathrm{p}=.48)$, oclusiva alveolar $(\mathrm{p}=.57)$, oclusiva velar $(\mathrm{p}=.60)$ e fricativa $(\mathrm{p}=$ .52), sem favorecimento significativo para sua aplicação. Em contrapartida, houve uma 
tendência considerável para a produção de $[\mathrm{m}]$ diante de vogal $(\mathrm{p}=.70)$ e para a sua não realização diante de oclusiva bilabial $(\mathrm{p}=.20)$.

É possível que a produção relativamente maior de [m] diante de vogal se deva ao fato de, nesse contexto, não ocorrer assimilação regressiva de ponto de articulação, o que permite ao segmento manter-se fiel à forma supostamente estabelecida como subjacente pelo aprendiz, /m/. Por outro lado, estando diante de consoante também bilabial, [p, b, m], [m] compartilha do ponto de articulação do segmento seguinte, retirando as pistas perceptuais que tornam possível identificá-lo como um segmento individual, o que explicaria o baixo número apresentado de realizações de [m] nesse contexto. Assim, especificamente para o contexto diante de oclusiva bilabial, uma análise acústica seria necessária; para os demais contextos, os quais não são homorgânicos, a análise de oitiva foi suficiente para descrever a natureza dos segmentos.

\subsubsection{Produção da vogal nasal + glide em posição final e de fronteira de palavra}

Dentre as 434 ocorrências de contextos relevantes, ou seja, de palavras com término em $<$ em $>,<\mathrm{im}>,<\mathrm{am}>,<\mathrm{om}>\mathrm{e}<\mathrm{um}>, 319$ foram produzidas ou com a sequência vogal nasal + glide, p. ex. [bẽj] 'bem', [kõw] 'com', ou sem a realização do glide ou de oclusivas nasais, p. ex. [bõ] 'bom' - para esse último caso, alternativamente, a velar [y] pode ter sido pronunciada, [bõy]. Procurou-se identificar os fatores que estariam motivando a realização de uma ou outra variável.

Os mesmos fatores linguísticos e extralinguísticos utilizados na análise de frequência da produção da nasal bilabial [m] foram utilizados aqui para a análise da frequência de aplicação do ditongo nasalizado, com exceção de contexto seguinte, por não se poder determinar as subcategorias potencialmente relevantes para a produção do ditongo em relação ao segmento seguinte. Diferentemente da assimilação regressiva pela qual passa a consoante nasal em coda, não foi encontrado na literatura em fonologia do PB, menção sobre a influência que formas seguintes a um ditongo exercem sobre ele.

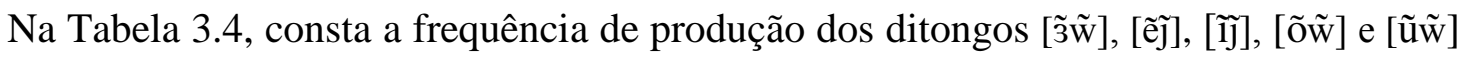
por informante em relação aos fatores linguísticos qualidade da vogal e tonicidade da sílaba e aos fatores extralinguísticos tempo de residência no país, nacionalidade e tempo de estudo formal de PL2, bem como os pesos relativos referentes aos fatores selecionados como relevantes para a aplicação do ditongo nasalizado. 
Tabela 3.4 - Resultados de frequência e peso relativo para a aplicação do ditongo nasalizado pelos informantes em posição final e de fronteira de palavra em relação a fatores linguísticos e extralinguísticos

\begin{tabular}{ccccc}
\hline Fatores relevantes & Subfatores & $\mathbf{N}$ & $\mathbf{\%}$ & Peso relativo \\
\hline \multirow{4}{*}{ qualidade da vogal } & $/ \mathrm{u} /$ & $6 / 67$ & 8 & $\mathbf{. 0 1}$ \\
& $/ \mathrm{o} /$ & $33 / 60$ & 55 & .25 \\
& $/ \mathrm{e} /$ & $136 / 139$ & 97 & .95 \\
& $/ \mathrm{i} /$ & $16 / 34$ & 47 & .19 \\
& $/ \mathrm{a} /$ & $8 / 19$ & 42 & $\mathbf{. 0 7}$ \\
\hline \multirow{2}{*}{ tempo de residência no } & 3 meses & $12 / 24$ & 50 &. $\mathbf{2 2}$ \\
país & $2-3$ anos & $77 / 115$ & 66 & $\mathbf{. 7 5}$ \\
& $9-10$ anos & $66 / 110$ & 60 & .30 \\
& $20-31$ anos & $44 / 70$ & 62 & .46 \\
\hline \multirow{2}{*}{ nacionalidade } & americana & $89 / 134$ & 67 & $\mathbf{. 6 9}$ \\
& britânica & $103 / 185$ & 59 & $\mathbf{. 3 5}$ \\
\hline Fatores não relevantes & & & & \\
\hline \multirow{2}{*}{ tonicidade da sílaba } & tônica & $100 / 122$ & 81 & - \\
& átona & $99 / 197$ & 50 & - \\
\hline \multirow{2}{*}{ tempo de estudo formal } & nenhum & $73 / 109$ & 67 & - \\
de PL2 & menos de 6 meses & $71 / 132$ & 53 & - \\
& $2-3$ anos & $55 / 78$ & 70 & - \\
\hline \multirow{2}{*}{} & & & \multicolumn{2}{c}{ significância $=0.000$}
\end{tabular}

Conforme apresentado na Tabela 3.4, o programa Goldvarb selecionou qualidade da vogal, tempo de residência no país e nacionalidade, nessa ordem, como fatores relevantes para a produção do ditongo nasalizado - quanto mais próximo a 1, mais favorável à aplicação.

A sequência /eN/ foi mais produtiva que as demais, com 139 ocorrências, além de ter sido a sequência em que o ditongo nasalizado foi mais recorrente, $97 \%$ dos casos. Esse resultado provavelmente se deve à frequência lexical de formas com /eN/ em PB e à saliência que $/ \mathrm{e} /+[\mathrm{j}]$ possuem, assim como $/ \mathrm{o} /+[\mathrm{w}]$, que vem em segundo lugar de frequência de realização do ditongo. A não ditongação das formas /iN/ e /uN/ pode estar associada a sua baixa saliência fonética, em que há menos perda de material fonético do que na produção de /eN/ e /oN/ sem a realização do ditongo.

Das 19 ocorrências de /aN/, desconsiderando as formas produzidas com a bilabial [m],

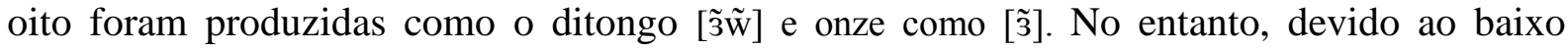
número de ocorrências totais de <am>, os dados que constam da tabela com relação a produção dessa sequência são inconclusivos.

Os valores para peso relativo revelam, novamente, tempo de residência como fator extralinguístico de relevância para a aplicação de dado processo da interlíngua, mas não em ordem diretamente proporcional. Embora os falantes com pouco tempo de residência no país (3 meses) tenham sido os que menos produziram ditongos nasalizados $(\mathrm{p}=.22)$, os 
informantes que mais os produziram foram os que estão em um período de tempo intermediário no país, entre 2 e 3 anos ( $\mathrm{p}=.75)$, e não os informantes mais experientes (residentes no país há mais de 9 anos).

Pela primeira vez, o fator nacionalidade foi selecionado como relevante, informantes americanos tenderam a produzir mais ditongos nasalizados do que falantes britânicos. No entanto, quando se observa os valores absolutos para a produção do ditongo para cada um dos dois grupos, verifica-se que não há muita disparidade entre eles. De 134 contextos relevantes na fala de americanos, houve 89 ocorrências de ditongo (67\%) e, de 185 contextos relevantes na fala de britânicos, houve 103 ocorrências de ditongo (59\%). Dentre os fatores selecionados como relevantes pelo programa, esse se mostrou o menos significativo.

Conclui-se, então que, no que concerne à produção da vogal nasal em PL2 pelos informantes, o tempo de residência no país exerce influência tanto na produção de [m] quanto na produção do glide, sendo o contexto linguístico seguinte também relevante para a realização de [m], e a qualidade da vogal precedente, para a realização do glide.

O capítulo seguinte trata da análise dos resultados referentes à produção da vogal nasal, assim como dos resultados referentes ao (não) vozeamento da fricativa alveolar pelos informantes, sob o modelo baseado em restrições proposto pela TO. 


\section{ANÁLISE}

Neste capítulo, são analisados via Teoria da Otimidade os dois aspectos da fonologia da interlíngua do aprendiz anglófono de PL2 que caracterizam o objeto de estudo deste trabalho: a ausência de assimilação regressiva de vozeamento envolvendo a fricativa alveolar final diante de segmento sonoro e a produção das oclusivas nasais [m, n] em posição final e de fronteira de palavra. Os ranqueamentos referentes ao primeiro estágio de aquisição de ambos os aspectos pelo aprendiz anglófono de PL2 serão formalizados, assim como os ranqueamentos referentes ao inglês e ao português.

\subsection{ANÁLISE VIA TEORIA DA OTIMIDADE DO (NÃO) VOZEAMENTO DA FRICATIVA ALVEOLAR EM POSIÇÃO DE FRONTEIRA DE PALAVRA}

O (não) vozeamento de obstruintes em coda final de palavra é um fenômeno já analisado em um dos primeiros estudos sobre aquisição de L2 sob o viés otimalista. Broselow et al. (1998) analisaram o não vozeamento de obstruintes finais do inglês como L2 por falantes nativos de mandarim, constatando a transferência da hierarquia de restrições da L1 para a interlíngua do falante, assim como a emergência de padrões não marcados. No entanto, são incomuns estudos sobre aquisição de padrões assimilatórios de vozeamento em L2 que se utilizem do modelo proposto pela TO.

As análises aqui apresentadas baseiam-se, fundamentalmente, em Cebrian (1999), Grijzenhout (2000), Lombardi (1999), McCarthy (2002) e McCarthy e Prince (1995), que discorreram sobre padrões de vozeamento em diversas línguas, como inglês, alemão, catalão, polonês e holandês. A partir das considerações feitas por esses autores e de suas propostas de hierarquias para as línguas que analisam, propõe-se aqui estabelecer as hierarquias responsáveis pelo padrão de vozeamento do inglês, do português e da interlíngua do aprendiz anglófono em seu primeiro estágio de aprendizagem, o qual corresponde, neste trabalho, aos três primeiros meses de residência do aprendiz no Brasil. 


\subsubsection{Formalização da hierarquia de restrições para o PB e para o inglês}

\subsubsection{Neutralização e contraste em posição final de palavra}

No que concerne ao ranqueamento de restrições de marcação e fidelidade que governam o vozeamento de obstruintes em posição final de palavra, inglês e PB se diferenciam. Em PB, [s] e [z] são neutralizados nessa posição (BISOL, 2005; CAGLIARI, 2007; MATTOSO CÂMARA JR., 2007 [1970]), enquanto em inglês, o falante nativo tende a manter-se fiel à representação lexical subjacente (GIMSON; CRUTTENDEN, 2008; MYERS, 2010; ROCA; JOHNSON, 1999; SMITH, 1997). Sob uma abordagem otimalista, esse fato pode indicar que, no que se refere ao vozeamento da obstruinte final, as duas línguas estejam assumindo diferentes restrições como prioritárias em sua hierarquia.

Conforme visto anteriormente, o não vozeamento de obstruintes em final de palavra é um aspecto não marcado característico de muitas línguas (p. ex. alemão, catalão, holandês, polonês). Esse aspecto pode ser representado por uma restrição universal que milita contra o vozeamento de obstruintes em posição final de sílaba, expressa em (1).

(1) $]_{\sigma} / *$ VoICE - obstruintes vozeadas são proibidas em posição final de sílaba (MCCARTHY, 2002)

Em conflito com a restrição de marcação $]_{\sigma} / *$ VoICE, há a restrição de fidelidade que milita em favor da manutenção do traço de vozeamento do input, apresentada em (2).

(2) IDENT(voice) - segmentos correspondentes no input e no output devem ter valores idênticos para o traço de sonoridade (MCCARTHY; PRINCE, 1995)

A restrição $]_{\sigma} / *$ VOICE estaria em posição diferente na hierarquia de cada um dos idiomas: em inglês, seria dominada pela restrição de fidelidade ao vozeamento do input, IDENT(voice). Em contrapartida, em PB, ocorreria o ranqueamento contrário, $]_{\sigma} / *$ VOICE $>>$ IDENT(voice), o que responderia pelo fato de as fricativas alveolares em final de palavra serem surdas no idioma.

$\mathrm{O}$ argumento para a hierarquia $]_{\sigma} / *$ VOICE $>>$ IDENT(voice) em PB decorre do fato de que, na aquisição de L1, restrições de marcação dominam restrições de fidelidade (DEMUTH, 1995; SMOLENSKY, 1996; GNANADESIKAN, 2004), não havendo, em PB, inputs que comprovem a modificação desse ranqueamento no decorrer do processo de aquisição.

Os efeitos da restrição $]_{\sigma} / *$ VOICE são tidos como invisíveis ou irrelevantes em inglês. No que concerne à coda final, a língua permite tanto obstruintes não vozeadas quanto 
obstruintes vozeadas, p. ex. bat [bæt] 'morcego' vs. bad [bæd] 'mau'. O que garante o contraste de vozeamento entre as obstruintes finais é a posição dominante da restrição de fidelidade IDENT(voice) na hierarquia, operando a favor da manutenção do vozeamento do input, conforme verificado em (3) para a palavra his ‘dele'.

(3) Contraste em coda final de palavra (inglês)

F: IDENT(voice) >> M: ] $/$ /*VOICE

\begin{tabular}{|c||c|c|}
\hline hiz/ & IDENT(voice) & lo $_{\sigma}^{*}$ VOICE \\
\hline \hline a. hiz & & $*$ \\
\hline b. his & $* !$ & \\
\hline
\end{tabular}

A violação da restrição de fidelidade IDENT(voice), prioritária na hierarquia, pelo candidato [his] é fatal, fazendo com que esse candidato saia da disputa. O fato de essa restrição ocupar uma posição alta na hierarquia do inglês, dominando a restrição de marcação ]$_{\sigma} / *$ VoIcE, resulta, portanto, na preferência pelo candidato fiel, ou seja, pelo candidato que possui obstruinte final vozeada, [hız], tal como a forma do input.

Em PB, no entanto, conforme visto, a restrição $]_{\sigma} / *$ VoICE possui valor elevado na hierarquia, dominando a restrição de correspondência entre o traço de vozeamento do output e o traço de vozeamento do input, IDENT(voice), conforme expresso em (4).

(4) Neutralização em coda final de palavra (PB)

M: $]_{\sigma} / * \operatorname{VoICE}>>$ F: IDENT(voice)

\begin{tabular}{|c|c|c|}
\hline$/$ mas/ & ]$_{\sigma} / *$ VOICE & IDENT(voice) \\
\hline \hline a. maz & $* !$ & $*$ \\
\hline \hline b. mas & & \\
\hline \hline amaz/ & & \\
\hline a. maz & $* !$ & $*$ \\
\hline
\end{tabular}

Verifica-se em (4) a escolha pela contraparte não vozeada da fricativa alveolar: [mas]. O outro candidato a output, [maz], viola a restrição que requer obstruintes não vozeadas em posição final de sílaba (e, consequentemente, de palavra), o que se caracteriza como violação fatal, com a consequente eliminação desse candidato.

Vale ressaltar que a ordem estabelecida para as restrições IDENT(voice) e $]_{\sigma} / *$ VOICE levaria à escolha de [mas] como output ótimo em PB independentemente da forma que lhe 
serviu como input, /mas/ ou /maz/. Pelo pressuposto da Riqueza de Base (SMOLENSKY, 1996), não há restrições ao input, sendo qualquer forma possível. Segundo Smolensky (1996), o conjunto de inputs direcionados às gramáticas é o mesmo para todas as línguas, as diferentes hierarquias é que são responsáveis pelos diferentes inventários gramaticais ou outputs ótimos. No entanto, apesar de haver certa "liberdade” na adoção de inputs, essas formas devem obedecer a propriedades básicas e universalmente respeitadas - não se assumiria, por exemplo, /batata/ como input para [pe.re] ou /txrt/ para [flor].

Além da interação entre $]_{\sigma} / *$ VOICE e IDENT(voice), utilizada nos ranqueamentos apresentados até agora, outras formalizações que expressam o (não) vozeamento da obstruinte final e, como se verá a seguir, que expressam processos assimilatórios, serão aqui consideradas.

Lombardi (1999), por exemplo, de modo a representar a assimetria no padrão de vozeamento entre onset e coda, presente em várias línguas, utiliza-se da interação entre três restrições, as quais seguem expressas em (5), (6) e (7).

(5) IDLAR - consoantes devem ser fiéis à especificação subjacente do traço de vozeamento

(6) IDONSLAR - consoantes em onset devem ser fiéis à especificação subjacente do traço de vozeamento

(7) * *AR - traços laríngeos não são permitidos

As restrições IDLAR e IDONSLAR originam-se da família de restrições de fidelidade à especificação de traço IDENT (F), proposta por McCarthy e Prince (1995). Lombardi (1999), no entanto, difere desses autores ao considerar o traço de vozeamento como privativo, e não como binário. Consoantes vozeadas teriam o traço [sonoro], ou "laríngeo”, e as não vozeadas não teriam esse traço. Assim, em vez de se considerar um segmento como [+sonoro] ou [sonoro], Lombardi apenas considera a presença ou a ausência do traço [sonoro].

A restrição IDONSLAR caracteriza-se como uma restrição de fidelidade posicional, pois atua em uma posição específica da sílaba, o onset. Desde Trubetzkoy (1969 [1939]), já se considerava as posições de onset e coda como assimétricas, o que refletiria uma tendência comum nas línguas em haver preservação de contrastes em onset e neutralização em coda. IDONSLAR seria a versão da TO para esse pressuposto.

Em (8), é apresentado o ranqueamento para o português como L1, baseando-se no ranqueamento de Lombardi (1999) para línguas que possuem neutralização de vozeamento em posição final de palavra. 
(8) Neutralização em coda final de palavra (PB)

IDONSLAR $>>*$ LAR $>>$ IDLAR

\begin{tabular}{|c||c|c|c|}
\hline /dois/ & IDONSLAR & $*$ LAR & IDLAR \\
\hline \hline a. dojz & & $* * !$ & $*$ \\
\hline b. dojs & & $*$ & $*$ \\
\hline c. tojs & $* !$ & & $*$ \\
\hline
\end{tabular}

Nota-se em (8), que a forma com modificação no traço de vozeamento do onset é prontamente eliminada, por violar a restrição IDONSLAR, prioritária na hierarquia. Devido ao empate entre (8a) e (8b) em IDONsLAR, a disputa entre esses dois candidatos passa à restrição seguinte, *LAR. O candidato (8a) é eliminado por conter mais violações de *LAR do que o candidato (8b), o que leva esse último a vencer a disputa.

Considera-se aqui que a prioridade de IDOnSLAR na hierarquia do PB consolida-se já nos primeiros estágios de aquisição do idioma como L1, em que a criança falante nativa com 2;5 anos de idade já domina o contraste de vozeamento entre os fonemas /s/ e /z/, por exemplo (SILVA, 2008). O ranqueamento *LAR >> IDLAR seria a conservação da dominância de restrições de marcação sobre restrições de fidelidade, proveniente ainda do início do processo de aquisição de L1 (DEMUTH, 1995; SMOLENSKY, 1996; GNANADESIKAN, 2004). Esse ranqueamento, no entanto, passa a ter seus efeitos obscurecidos por conta da prioridade de IDONSLAR.

Em inglês, o fato de ser admitido o contraste de vozeamento em coda silábica é expresso, segundo Lombardi (1999), pela hierarquia IDLAR $>>*$ LAR, IDONSLAR, indicando que no idioma a identidade de vozeamento deve ser mantida tanto em onset quanto nas demais posições da sílaba. O ranqueamento das posições abaixo de IDLAR não são relevantes em inglês, cujo “vozeamento irrestrito”, segundo Lombardi, é expresso em (9), utilizando-se a palavra days ‘dias’ como input.

(9) Vozeamento irrestrito (inglês)

IDLAR $>>*$ LAR, IDONSLAR

\begin{tabular}{|c||c|c|c|}
\hline /deIz/ & IDLAR & $*$ LAR & IDONSLAR \\
\hline \hline a. deIz & $* !$ & $*$ & \\
\hline b. deIs & $* * !$ & & $*$ \\
\hline c. teIs & $* !$ & $*$ & $*$ \\
\hline d. teIz & $* !$ & & \\
\hline
\end{tabular}


Em (9), são eliminados todos os candidatos que violaram IDLAR (9b, 9c, 9d), independentemente da posição da sílaba em que essa violação ocorreu, se em onset (9c, 9d) ou coda (9b). IDONSLAR deixa de ser restrição relevante - IDLAR já inclui os efeitos que IDONSLAR teria -, podendo vir em qualquer posição na hierarquia. A violação de restrições abaixo de IDLAR não resulta em eliminação, e, como indica o traçado pontilhado, também não há relação de dominância entre essas restrições.

Um dos pressupostos da TO é o de que as restrições sejam “forças” presentes em todas as línguas, o que varia é o grau de atuação dessas forças, fazendo-se ou não relevantes de acordo com o idioma. Nesse sentido, a restrição ou conjunto de restrições que operam a favor do não vozeamento em coda final de palavra podem também atuar em inglês, explicando, por exemplo, o desvozeamento parcial observado por alguns estudiosos da fonética do inglês nessa posição da sílaba, como Smith (1997).

Para os propósitos deste trabalho, a gradiência fonética não será considerada. Em outros termos, a assimilação regressiva desencadeada por segmento vozeado em fronteira de palavra será tratada como um processo fonológico, presente em determinadas línguas, como o português, e ausente em outras, como o inglês. Ainda que se admita a gradiência da cadeia de sons da fala, opta-se aqui por “recortes” fonológicos, e não fonéticos.

\subsubsection{Concordância de vozeamento em cluster}

Para expressar o não vozeamento em posição final absoluta, tanto a interação entre as restrições $]_{\sigma} / *$ VOICE e IDENT(voice) (MCCARTHY, 2002) quanto a interação entre as restrições IDLAR, *LAR e IDONSLAR (LOMBARDI, 1999) podem representar, de maneiras diferentes, essa tendência das línguas. No entanto, como se verá adiante, para explicar a assimilação regressiva em fronteira de palavra envolvendo clusters e a sequência obstruinte + vogal, novas formalizações deverão ser estabelecidas.

A tendência não marcada das línguas para que duas obstruintes adjacentes compartilhem o mesmo traço de vozeamento pode ser representada pela restrição AGREE (10).

(10) AGREE - clusters de obstruintes devem concordar em vozeamento (MCCARTHY; PRINCE, 1995)

AGREE em posição elevada na hierarquia, acima de restrições de fidelidade, faz com que os elementos de um cluster apresentem o mesmo traço de vozeamento, suprimindo na forma de superfície o contraste que haveria na forma subjacente. 
De acordo com Lombardi (1999), além de serem responsáveis pela neutralização em posição final, as restrições posicionais também dão conta de processos assimilatórios quando AGREE é incluso na análise. Ambos os processos, a neutralização e a assimilação de vozeamento, costumam atingir a coda, mas não o onset, onde as distinções geralmente são mantidas.

A assimilação regressiva de vozeamento em línguas que possuem neutralização de vozeamento de obstruintes em coda pode ser expressa pelo ranqueamento em (11), proposto por Lombardi (1999) e aqui adaptado para o português. Vale ressaltar que foi estendida aqui a relevância de AGREE para a posição de fronteira de palavra - Lombardi faz referência apenas à posição de interior de palavra e de fronteira de palavra composta.

(11) Assimilação regressiva de vozeamento (PB)

AGREE, IDONSLAR $>>*$ LAR $>>$ IDLAR

\begin{tabular}{|c||c|c|c|c|}
\hline /desde/ & AGREE & IDONSLAR & $*$ LAR & IDLAR \\
\hline \hline a. de[sd]e & $* !$ & & $*$ & \\
\hline b. de[zd]e & & & $* *$ & $*$ \\
\hline c. de[st]e & & $* !$ & & $*$ \\
\hline \hline /os\#dois/ & & & & \\
\hline \hline a. o[s d]ois & $* !$ & & $*$ & $*$ \\
\hline b. o[z d]ois & & & $* *$ & $*$ \\
\hline c. o[s t]ois & & $* !$ & & $*$ \\
\hline
\end{tabular}

AGREE, em posição dominante na hierarquia, faz com que os elementos do cluster compartilhem do mesmo traço de vozeamento, eliminando candidatos que possuam elementos do cluster divergentes para esse traço, como os candidatos (11a). A eliminação ocorre independentemente de esses candidatos satisfazerem IDLAR, restrição que vem baixa na hierarquia, podendo ser violada. IDONSLAR é tão importante na hierarquia quanto AGREE, assim, além dos candidatos (11a), são também eliminados os candidatos (11c), esses últimos por violarem IDONSLAR. Por fim, são selecionados como outputs ótimos a palavra 'de[zd]e' e a sequência 'o[z d]ois', por não violarem as restrições prioritárias AGREE e IDONSLAR, mesmo que, para isso, tenham tido que violar *LAR e IDLAR.

De acordo com Lombardi (1999), a posição elevada de IDONSLAR e AGREE responde para que o tipo de assimilação seja regressivo: a obstruinte em coda não exerce influência 
sobre o onset da sílaba seguinte, que mantém seu traço de vozeamento, é a obstruinte em coda que deve se adequar ao vozeamento do segmento seguinte.

Cabe aqui ressaltar que, em português, para inputs com clusters não vozeados (sem traços laríngeos, conforme abordagem adotada por Lombardi), as restrições seriam satisfeitas no vácuo: os outputs ótimos para ‘de/st/e’ e ‘o/s t/rês', por exemplo, seriam ‘de[st]e’ e ‘o[s t]rês', os quais não violam nenhuma das restrições em conflito, satisfazendo tanto as restrições de fidelidade ao input (IDONSLAR e IDLAR) quanto às de marcação em favor de obstruintes surdas (*LAR) e da concordância de vozeamento entre obstruintes de um cluster (Agree).

Em inglês, língua tida como de vozeamento irrestrito, conforme Lombardi (1999), IDLAR domina as demais restrições. O ranqueamento IDLAR $>>$ *LAR, AGREE demonstra que há fidelidade ao traço de vozeamento do input, independentemente da posição que o elemento ocupa na sílaba, se em coda ou onset, conforme se verifica em (12).

(12) Vozeamento irrestrito de obstruintes (inglês) (LOMBARDI, 1999, p. 277)

IDLAR $>>*$ LAR, AGREE

\begin{tabular}{|c|c|c|c|c|}
\hline /pigpen/ & IDONSLAR & IDLAR & *LAR & AGREE \\
\hline a. pi[gp]en & & & * & * \\
\hline b. pi[kp]en & & $* !$ & & \\
\hline c. pi[gb]en & * & $* !$ & ** & \\
\hline \multicolumn{5}{|l|}{ /catbird/ } \\
\hline a. ca[tb]ird & & & * & * \\
\hline b. ca[db]ird & & $* !$ & ** & \\
\hline c. ca[tp]ird & * & $* !$ & & \\
\hline \multicolumn{5}{|l|}{ /pegboard/ } \\
\hline a. pe[gb]oard & & & ** & \\
\hline b. pe[kb]oard & & $* !$ & * & * \\
\hline c. pe[kp]oard & * & **! & & \\
\hline
\end{tabular}

Em inglês, a restrição geral IDLAR vem em posição prioritária no ranqueamento, fazendo com que a restrição mais específica IDONSLAR perca seu efeito, podendo vir em qualquer posição na hierarquia. As restrições de marcação *LAR e AGREE podem ser violadas a fim de que a restrição de fidelidade IDLAR seja satisfeita. Dessa forma, os candidatos (12a) 
são selecionados como outputs ótimos, simplesmente por não violarem a restrição de fidelidade IDLAR. A violação das restrições de marcação *LAR e AGREE é tolerável no idioma.

A tipologia adotada por Lombardi (1999), no entanto, apresenta algumas limitações: não dá conta de algumas especificidades de assimilação de vozeamento em inglês, as quais serão referidas a seguir, e de certos tipos de processos assimilatórios presentes em algumas línguas, como o holandês, os quais fogem ao escopo deste trabalho.

Em inglês, em alguns casos morfológicos, são as restrições de marcação que dominam, indicando que o vozeamento nessa língua talvez não seja “irrestrito”, como proposto por Lombardi (1999). Como exemplos, cita-se: a) a assimilação progressiva de vozeamento, em que morfemas de plural dos nomes, da $3^{\mathrm{a}}$ pessoa do verbo no singular e do genitivo devem concordar em vozeamento e b) casos de raiz + afixos, como em five + th $>$ fifth [frf $\theta$ ] 'quinto' e wide + th > width [wit $\theta$ ] 'largura', em que se tem os elementos do cluster passando a concordar em vozeamento (GRIJZENHOUT, 2000).

Lombardi (1999), no entanto, oferece uma explicação para o item (a), adicionando uma restrição denominada Harms’ Generalization, expressa em (13).

(13) Harms' Generalization - obstruintes vozeadas devem estar mais próximas ao núcleo silábico do que obstruintes não vozeadas

Essa restrição de boa formação silábica viria à frente de IDLAR e proibiria formas como *[kætz] cats 'gatos', por exemplo, que contêm um som posvocálico não vozeado [t] diante de som vozeado [z] na margem direita da sílaba, indo contra a escala de sonoridade. Em (14) está o ranqueamento para cats.

(14) Assimilação progressiva de vozeamento (inglês) (LOMBARDI, 1999, p. 289)

HARM’S GEN. >> IDLAR >> *LAR

\begin{tabular}{|c||c|c|c|}
\hline$/$ kæt + z/ & HARM’s GEN. & IDLAR & $*$ LAR \\
\hline \hline a. kætz & $* !$ & & $*$ \\
\hline b. kædz & & $*$ & $* * !$ \\
\hline c. kæts & & $*$ & \\
\hline
\end{tabular}

O output (14a) é eliminado por violar a restrição HARM’s GEN., já que [tz] cresce em sonoridade em direção oposta ao núcleo. Tanto (14b) quanto (14c) violam IDLAR, assim o output ótimo é decidido pela restrição seguinte, *LAR. O candidato (14c) é então escolhido como ótimo. 
Esse tipo de saída proposto por Lombardi para que a assimilação progressiva de vozeamento possa ser explicada pela mesma hierarquia estabelecida anteriormente para o inglês não é tida como adequada por Grijzenhout (2000) que, por sua vez, propõe um novo ranqueamento.

Grijzenhout (2000) utiliza-se de um novo formalismo para explicar o status do vozeamento de obstruintes em inglês, mas não abandona o pressuposto de que existam restrições posicionais. A autora utiliza-se de uma restrição de identidade limitada ao domínio morfológico do radical (=stem), propondo que restrições de domínio morfológico e prosódico, portanto, posicionais, possam dar conta da alternância de vozeamento de obstruintes em diferentes contextos fonológicos. A restrição que se refere ao domínio do radical (15) seria, segundo a autora, relevante na hierarquia do inglês.

(15) IDENTSTEM (voice) - um segmento [ $\alpha$ voice] de um radical no input é $[\alpha$ voice] no output

No que concerne ao domínio do radical, essa restrição significa que o traço de sonoridade de um segmento no input deve se manter no output. A restrição de identidade IDENTSTEM (voice) milita então a favor da correspondência entre o traço de vozeamento do radical pertencente ao input e do radical pertencente ao output. O output ca[dz] para cats 'gatos', por exemplo, violaria essa restrição, pela falta de correspondência entre o traço de vozeamento do input e output, no que corresponde ao domínio morfológico do radical, que, nesse caso, deveria ser em /t/, e não em /d/.

Grijzenhout (2000) também inclui FinALDev(OICING) em seu ranqueamento, que corresponde à $]_{\sigma} / *$ VOICE, restrição que milita contra o vozeamento de obstruintes em posição final de sílaba, já anteriormente apresentada. Além disso, leva em conta a binariedade do traço de vozeamento, a restrição *[+voice] corresponderia à restrição de caráter mais geral que impede obstruintes vozeadas, em contraste com *LAR, que impede traços laríngeos.

Grijzenhout (2000) propõe um ranqueamento que serve tanto para a assimilação progressiva do inglês quanto para a "assimilação regressiva de desvozeamento" que ocorre em palavras como fifth [f $\theta$ ] 'quinto', além de poder dar conta de clusters em fronteira de palavra.

Em (16) está o ranqueamento proposto por Grijzenhout (2000) para as palavras fifth ‘quinto', cats 'gatos' e para a combinação dog fight 'luta de cães'. 
(16) Assimilação de vozeamento (inglês) (GRIJZENHOUT, 2000, p. 9-10)

IDENTSTEM(voice) $>>$ AGREE $>>$ IDENT(voice) $>>$ FINALDEV $>>*$ [+voice $]$

\begin{tabular}{|c|c|c|c|c|c|}
\hline $\mathrm{fi} / \mathrm{v} /$ root $+/ \theta /$ & $\begin{array}{l}\text { IDENTSTEM } \\
\text { (voice) }\end{array}$ & AgREE & $\begin{array}{l}\text { IDENT } \\
\text { (voice) }\end{array}$ & FINALDEV & $*[+$ voice $]$ \\
\hline a. fi[v $\theta]$ & & $* !$ & & & $*$ \\
\hline b. fi[vð] & & & * & $* !$ & $* *$ \\
\hline с. fi[f $\theta]$ & & & $*$ & & \\
\hline
\end{tabular}

\begin{tabular}{|c||c|c|c|c|c|}
\hline \hline $\mathrm{ca} / \mathrm{t} / \mathrm{stem}+/ \mathrm{z} /$ & & & & & \\
\hline \hline a. ca[tz] & & $* !$ & & $*$ & $*$ \\
\hline b. ca[dz] & $* !$ & & $*$ & $*$ & $* *$ \\
\hline c. ca[ts] & & & $*$ & & \\
\hline
\end{tabular}

\begin{tabular}{|c||c|c|c|c|c|}
\hline \hline do/g/stem $+/ f /$ ight stem & & & & & \\
\hline \hline a. do[g f]ight & & $*$ & & $*$ & $*$ \\
\hline b.do[g v]ight & $* !$ & & $*$ & $*$ & $* *$ \\
\hline c. do[k.f]ight & $* !$ & & $*$ & & \\
\hline
\end{tabular}

A restrição IDENTSTEM(voice) é violada pelos candidatos que alteram o traço de vozeamento da obstruinte do radical: 'ca[dz]', 'do[g v]ight' e 'do[k f]ight'. O candidato fi[f $\theta$ ] não viola IDENTSTEM(voice) pelo fato de sua alteração ser no vozeamento da obstruinte final que ocupa a raiz (=root), e não o radical $^{19}$.

Nota-se que a restrição AGREE não é violada por nenhum dos candidatos (16b) ou (16c), já os candidatos (16a), ‘fi[v $\theta$ ]’ e ‘ca[tz]', saem da disputa justamente por violarem essa restrição. No entanto, em posição de fronteira de palavra, devido à prioridade de IDENTSTEM(voice), que elimina os candidatos 'do[g v]ight e 'do[k f]ight', vence o candidato (16a), 'do[g f]ight'.

Na hierarquia proposta para o inglês por Grijzenhout (2000) em (16), para que a posição de interior de palavra seja contemplada, ou a "assimilação de desvozeamento" que ocorre nessa posição, IDENT(voice) passa a ser dominada na hierarquia. A violação de IDENT(voice), juntamente com a violação de FINALDEV e *[+voice], passa a ser irrelevante na escolha do candidato ótimo.

Grijzenhout (2000) diferencia-se de forma significativa de Lombardi (1999), não apenas por dar conta, em uma mesma hierarquia, da "assimilação de desvozeamento" tanto

\footnotetext{
${ }^{19}$ De acordo com Grijzenhout (2000), nessa abordagem, é importante que o morfema do input seja especificado como raiz (=root) ou radical (=stem), o que basicamente depende dos afixos que a eles se juntam.
} 
progressiva quanto regressiva em interior de palavra e da fidelidade ao traço de vozeamento em fronteira de palavra, mas também por, ao demover a restrição IDENT(voice), mostrar que o inglês não é tão fiel assim ao vozeamento subjacente.

No entanto, Grijzenhout (2000) não faz referência à "assimilação regressiva de desvozeamento” que também pode ocorrer em fronteira de palavra, conforme visto em 1.3.1.2, em que fricativas e africadas finais vozeadas passam a ser desvozeadas diante de um segmento não vozeado, p. ex. lose ten-nil 'perder de dez a zero', em que /lu:z/ torna-se [lu:s] diante do segmento surdo [t]. Ocorrências desse tipo violariam a restrição estabelecida por Grijzenhout como prioritária na hierarquia do inglês, IDENTSTEM (voice).

No presente trabalho, não se propõe encontrar uma solução para esse impasse, uma vez que a posição da fricativa precedendo obstruinte surda não vai ser analisada na interlíngua dos informantes, apenas a posição que precede segmentos vozeados. Para a ausência de assimilação regressiva de vozeamento no que concerne ao cluster heterossilábico em fronteira de palavra [-sonoro][+sonoro], tanto a hierarquia estabelecida por Lombardi (1999) quanto a hierarquia de Grijzenhout (2000) propõem-se a dar conta do fenômeno, diferenciando-se quanto ao uso das restrições prioritárias e no tratamento do traço de vozeamento, privativo no primeiro caso e binário no segundo. No entanto, nenhuma das duas abordagens faz referência à posição que antecede palavra iniciada por vogal e, para isso, será utilizada aqui mais uma abordagem, a de Cebrian (1999).

É importante que todas as três abordagens sejam apresentadas nesta parte para que seja justificada a escolha do ranqueamento para a interlíngua dos informantes, em que será feita uma síntese dos pressupostos fundamentais dessas análises.

Como visto, é consensual em PB que em posição final de palavra antecedendo vogal, /s/ seja realizado sistematicamente como [z], p. ex. 'ma/s/ aqui/' [ma.za'ki], havendo também ressilabificação, processo em que a coda em final de palavra torna-se onset da sílaba seguinte.

Ao contrário do tipo de assimilação de vozeamento que ocorre em clusters, a assimilação de vozeamento desencadeada por um segmento vocálico heterossilábico não é muito estudada via TO.

Para esta análise, será aqui utilizada a restrição proposta por Cebrian (1999) para dar conta do vozeamento de fricativas finais posvocálicas em catalão, expressa em (17).

(17) AGREE FV - a sequência heterossilábica obstruinte contínua + vogal deve concordar em vozeamento 
Como se pode notar, Cebrian (1999) utiliza-se de uma restrição ligada à AGREE, referente à concordância entre elementos de um cluster consonantal. Para justificar a escolha dessa restrição, Cebrian argumenta que as fricativas são alvos mais fáceis para a assimilação de vozeamento do que as obstruintes de modo geral. A autora demonstra haver uma proximidade importante entre vogais e fricativas, que, sobretudo, advém do seu modo de articulação, ambas são contínuas. Em catalão, por exemplo, as fricativas finais podem ser vozeadas tanto por obstruinte vozeada quanto por vogal heterossilábica seguinte, diferente das oclusivas finais, que apenas são vozeadas regressivamente por outra obstruinte, o que demonstra a afinidade entre vogais e fricativas.

O caráter peculiar de vozeamento das fricativas em relação às demais obstruintes também é expresso pela restrição *VsV, utilizada por Kenstowicz (1996) e Krämer (2003) na análise do dialeto vêneto do italiano, apresentada em (18).

(18) *VsV - a fricativa alveolar /s/ em posição intervocálica de interior de palavra prosódica não pode ser surda (KENSTOWICZ, 1996)

Para a formalização de *VsV, Kenstowicz baseia-se em Nespor e Vogel (1986), sobre o vozeamento do /s/ intervocálico, presente em palavras como di[z]-onesto ‘desonesto’.

Obstruintes, de modo geral, em posição intervocálica, tendem ao vozeamento, sendo a justificativa para esse fato articulatória. De acordo com Hayes (2004, p. 171), as formas que obedecem à restrição de vozeamento intervocálico não precisam alterar o gesto laríngeo, “desligando” o vozeamento quando o segmento está entre dois segmentos sonoros. Esse processo é evidenciado diacronicamente ao se comparar, por exemplo, as formas portuguesas com as dos cognatos latinos: prā[t]o $>$ pra[d]o, prŏ[f]ectu $>$ pro[v]eito, accū[s]āre $>$ acu[z]ar (FERREIRA NETTO, 2001, p. 70). Considerando os estudos de Cebrian (1999) e Kenstowicz (1996), essa restrição parece mostrar-se atuante, em alguns casos, especialmente em relação às fricativas.

Como *VsV limita-se à palavra prosódica, será utilizada aqui a restrição AGREE FV, que se refere à posição de fronteira de palavra. Apesar disso, assume-se que ambas as restrições sejam de mesmo caráter, reconhecem o status diferenciado da fricativa e sua maior suscetibilidade a ser alvo de processos assimilatórios.

Considerando, finalmente, que a restrição AgREE FV seja, junto com AGREE e IDONSLAR, prioritária na hierarquia do português, propõe-se aqui o seguinte ranqueamento para o idioma: 
(19) Assimilação regressiva de vozeamento para o português com base nas restrições de Cebrian (1999), Grijzenhout (2000) e Lombardi (1999)

Agree, AgREe FV, IDONSLAR >> FINALDEV >> IDENT(voice)

\begin{tabular}{|c||c|c|c|c|c|}
\hline /desde/ & AGREE & AGREE FV & IDONSLAR & *FINALDEV & IDENT(voice) \\
\hline \hline a. de[sd]e & $* !$ & & & & \\
\hline b. de[zd]e & & & & $*$ & $*$ \\
\hline c. de[st]e & & & $* !$ & & $*$ \\
\hline \hline /os\#dois/ & & & & & $*$ \\
\hline \hline a. o[s d]ois & $* !$ & & & & $*$ \\
\hline b. o[z d]ois & & & & & $*$ \\
\hline c. o[s t]ois & & & & & $*$ \\
\hline \hline /os\#outros/ & & & & & $*$ \\
\hline a. o[s o]utros & & $* !$ & & & $*$ \\
\hline b. o[z o]utros & & & & & $*$ \\
\hline
\end{tabular}

Em um mesmo ranqueamento de restrições é possível então dar conta da assimilação regressiva de vozeamento em português que ocorre em interior de palavra, com a escolha de 'de[zd]e' como output ótimo, em fronteira de palavra diante de consoante vozeada, em que 'o[z d]ois' é escolhido e, finalmente, em posição de fronteira de palavra diante de segmento vocálico, tendo ‘o[z o]utros’ como output ótimo.

Como IDENTSTEM não é relevante em português - tanto o sufixo plural da palavra 'casas', por exemplo, quanto a fricativa final da palavra 'mas' mudam de vozeamento diante de palavra iniciada por segmento sonoro, não havendo, portanto, identidade ao radical -, optou-se por utilizar apenas a restrição posicional IDONSLAR, conforme visto, atuante em português.

FinAlDev só pode ser violado ao custo de satisfazer Agree e Agree FV, as quais, propõe-se aqui, constituírem-se como restrições prioritárias na hierarquia do PB, governando o processo de assimilação de vozeamento.

Uma vez que neste trabalho não se está considerando o traço de sonoridade como privativo, a restrição *LAR é retirada. Ademais, a relevância de *LAR para o português e para o inglês estaria na sua interação com IDONSLAR e IDLAR, como houve a seleção de novas restrições, *LAR, de qualquer modo, perderia sua função.

Finalmente, propõe-se aqui uma hierarquia de restrições para o inglês, em que são utilizadas as restrições IDENTSTEM e FINALDEv, extraídas do ranqueamento de Grijzenhout, 
em (16), e onde é incluso AGREE FV (CEBRIAN, 1999), restrição que, embora seja irrelevante na hierarquia do inglês - não há ARV envolvendo a obstruinte contínua final diante de vogal -, segue expressa para efeitos de posterior comparação com a hierarquia da interlíngua.

(20) Assimilação regressiva de vozeamento para o inglês com base nas restrições de Cebrian (1999), Grijzenhout (2000) e Lombardi (1999) IDENTSTEM(voice) $>>$ AGREE >> IDENT(voice) >> FINALDEV >> AGREE FV

\begin{tabular}{|c|c|c|c|c|c|}
\hline $\mathrm{fi} / \mathrm{v} /_{\text {root }}+/ \theta /$ & $\begin{array}{c}\text { IDENTSTEM } \\
\text { (voice) } \\
\end{array}$ & AGREE & $\begin{array}{l}\text { IDENT } \\
\text { (voice) } \\
\end{array}$ & FINALDEV & AGREE FV \\
\hline a. fi[ve] & & $* !$ & & & \\
\hline b. fi[vð] & & & * & $* !$ & \\
\hline c. fi[f $[\mathrm{f}]$ & & & $*$ & & \\
\hline \multicolumn{6}{|l|}{$\mathrm{ca} / \mathrm{t} / /_{\text {stem }}+/ \mathrm{z} /$} \\
\hline a. ca[tz] & & $* !$ & & * & \\
\hline b. $\mathrm{ca}[\mathrm{dz}]$ & $* !$ & & $*$ & * & \\
\hline c. ca[ts] & & & $*$ & & \\
\hline \multicolumn{6}{|c|}{ do/g/stem $+/ f / i g h t_{\text {stem }}$} \\
\hline a. do[g f]ight & & * & & * & \\
\hline b. do[k f]ight & $* !$ & & $*$ & & \\
\hline \multicolumn{6}{|l|}{ /catbird/ } \\
\hline a. ca[tb]ird & & * & & & \\
\hline b. ca[db]ird & $* !$ & & $*$ & $*$ & \\
\hline \multicolumn{6}{|l|}{ /pegboard/ } \\
\hline a. pe[gb]oard & & & & * & \\
\hline b. pe[kb]oard & $* !$ & $*$ & * & & \\
\hline \multicolumn{6}{|l|}{ thi/s/ dog } \\
\hline (F) a. thi[s d]og & & * & & & \\
\hline b. thi[z d]og & $* !$ & & $*$ & * & \\
\hline \multicolumn{6}{|l|}{ thi/s/ animal } \\
\hline (F⿻ thi[s æ]nimal & & & & & $*$ \\
\hline b. thi[z æ]nimal & $* !$ & & * & * & \\
\hline
\end{tabular}


No tableau acima são prontamente eliminados os candidatos que não possuem correspondência de vozeamento entre input e output no que concerne ao domínio do radical, além de candidatos cujo segmento na raiz não concorda em vozeamento com a obstruinte tautossilábica seguinte. Candidatos que violam a restrição IDENT(voice), em favor da concordância com o segmento tautossilábico, são permitidos. No entanto, não são permitidos candidatos que violam IDENT(voice) em fronteira de palavra composta, podendo essa consideração ser estendida para a posição de fronteira de palavra, conforme visto no capítulo 1.3.1.2.

\subsubsection{Formalização da hierarquia de restrições para a interlíngua}

Não houve assimilação regressiva de vozeamento da fricativa alveolar diante de palavra iniciada por segmento vozeado (obstruinte vozeada, soante ou vogal) em dado momento da fala de todos os 11 informantes desta pesquisa. Como é característico da aprendizagem em L2, houve variação de caráter inter- e intra-individual, sendo o vozeamento diretamente proporcional ao tempo de residência do informante no país: a) 3 meses, $p=.22$; b) 2-3 anos, $\mathrm{p}=.36$; c) 9-11 anos, $\mathrm{p}=.72$; d) 20-31 anos, $\mathrm{p}=.77$, em que, quanto mais próximo o peso relativo for a 1 , maior a tendência à produção da contraparte vozeada da fricativa.

Pelos resultados, é possível afirmar que os informantes, assim como os aprendizes do português como L1 nos primeiros estágios de aquisição do idioma, estejam passando por um processo de aquisição da assimilação regressiva de vozeamento do português. No entanto, diferentemente dos aprendizes de português como L1, que de fato adquirem esse processo fonológico, passando a realizar sistematicamente o vozeamento da fricativa alveolar diante de segmento sonoro, os aprendizes anglófonos de PL2, mesmo que possuam muitos anos de exposição ao idioma, mais de vinte anos, por exemplo, ainda não realizam o vozeamento da fricativa de maneira categórica. A assimilação regressiva de vozeamento constitui-se ainda como um processo de variação na interlíngua desses aprendizes.

Nesta parte, será analisada, via Teoria da Otimidade, a produção dos informantes no que concerne ao processo fonológico de assimilação regressiva de vozeamento no início da aprendizagem do PL2. Portanto, não será realizada uma análise da produção dos informantes em cada etapa do tempo de residência, mas apenas haverá uma tentativa de se fazer conhecer a interação entre restrições de marcação e fidelidade presentes no contato inicial com o 
português (primeiros três meses de residência no Brasil) - embora se assuma aqui que essas não deixem de ser “forças” também atuantes na produção de falantes mais experientes.

No que concerne à aquisição de L2 analisada pelo modelo da TO, geralmente adota-se o pressuposto de que o falante inicia o processo de aquisição com a hierarquia de sua L1, eventualmente ocorrendo a emergência de padrões não marcados. Pretende-se aqui verificar o envolvimento entre transferência de L1 e efeitos de marcação sob um modelo que se acredita ser capaz de tornar essa interação explícita.

Confome Hancin-Bhatt (2008, p. 131), pela TO, é possível identificar o estágio inicial de aquisição da L2 pelo aprendiz, sobre como os efeitos de marcação são “decodificados” e como podem emergir na gramática da interlíngua, assim como é possível estabelecer, por meio do ranqueamento da L1, predições sobre como o aprendiz vai resolver estruturas fonológicas de L2 ainda não aprendidas.

Na descrição dos dados de fala dos informantes, verificou-se que a qualidade do segmento seguinte, se vogal, soante ou consoante obstruinte vozeada, assim como a tonicidade da sílaba, não foi selecionada como fator relevante pelo programa Goldvarb, e a característica morfêmica foi tida como fator pouco significativo para a aplicação do vozeamento. Assim, o fator tido como verdadeiramente relevante foi o tempo de residência no país.

O grupo de falantes residentes no país por três meses (MAC, BET, JON) raramente realizou a assimilação regressiva de vozeamento da fricativa alveolar, 75\% das ocorrências em contextos relevantes para a aplicação do vozeamento foram produzidas, por esses informantes, com a fricativa alveolar surda, como se pode notar nos exemplos abaixo:

$$
\begin{aligned}
& \text { amigo[s] no Brasil, dua[s] horas (MAC) } \\
& \text { todo[s] o[s] dias, ma[s] depoi[s] um pouco (BET) } \\
& \text { ma[s] aqui, meu[s] amigo[s] brasileiros (JON) }
\end{aligned}
$$

Assumindo-se, em princípio, que os informantes estejam se utilizando da mesma hierarquia do inglês, a hierarquia (22) foi estabelecida, estipulando como forma de input, primeiramente, /s/ ('ma/s/’, 'meu/s/’) e, em seguida, /z/ ('ma/z/', 'meu/z/'). 
(22) Ranqueamento com seleção de output ótimo incorreto (interlíngua)

IDENTSTEM(voice) $>>$ AGREE >> IDENT(voice) $>>$ FINALDEV >> AGREE FV

\begin{tabular}{|c|c|c|c|c|c|}
\hline $\mathrm{ma} / \mathrm{s} /$ stem $+/ \mathrm{d} /$ epois & $\begin{array}{l}\text { IDENTSTEM } \\
\text { (voice) } \\
\end{array}$ & AGREE & $\begin{array}{l}\text { IDENT } \\
\text { (voice) }\end{array}$ & FINALDEV & AGREE FV \\
\hline a. ma[s d]epois & & * & & & \\
\hline b. ma[z d]epois & $* !$ & & * & * & \\
\hline \multicolumn{6}{|l|}{ meu/s/ + /a/migos } \\
\hline a. meu[s a]migos & & & & & * \\
\hline b. meu[z a]migos & & & $* !$ & * & \\
\hline \multicolumn{6}{|l|}{$\mathrm{ma} / \mathrm{z} /_{\text {stem }}+/ \mathrm{d} /$ epois } \\
\hline a. ma[s d]epois & $* !$ & * & * & & \\
\hline (:) b. ma[z d]epois & & & & * & \\
\hline \multicolumn{6}{|l|}{ meu/z/ + /a/migos } \\
\hline a. meu[s a]migos & & & *! & & $*$ \\
\hline :) b. meu[z a]migos & & & & $*$ & \\
\hline
\end{tabular}

Conforme proposto por Grijzenhout (2000), para a hierarquia do inglês, AgREE foi colocado entre IDENTSTEM e IDENT(voice), de modo que essa mesma hierarquia também pudesse dar conta da concordância de vozeamento que existe entre clusters tautossilábicos em posição interna de palavra.

Pelo ranqueamento em (22), deve haver, prioritariamente, correspondência entre o traço de vozeamento do input e do output em relação à obstruinte que ocupa o radical. Pode não haver concordância de vozeamento entre obstruintes de um cluster, i.e. AGREE pode ser violada, desde que a restrição IDENTSTEM (voice) seja satisfeita, tal como ocorre com (22a).

Caso /s/ tenha sido a forma subjacente adotada pelos informantes - tanto para a obstruinte que ocupa o radical, 'mas', quanto para a obstruinte do sufixo plural, 'meus' -, pode-se assumir que eles, ao produzirem [s] como output, estejam se utilizando da hierarquia de restrições do inglês no início de sua aprendizagem do PL2, ao satisfazerem, de modo prioritário, IDENTSTEM(voice). Pode-se ainda considerar que os aprendizes estejam rerranqueando FINALDEV para uma posição superior na hierarquia, como se verá adiante.

O candidato a output ótimo que viola IDENTSTEM (voice), 'ma[z d]epois’ é eliminado, sendo 'ma[s] depois' escolhido como forma ótima, ainda que viole AGREE. As restrições abaixo de AGREE não têm relevância na disputa entre os candidatos. 
Alternativamente, pode se considerar que os informantes tenham a fricativa alveolar vozeada, /z/, como forma subjacente. Apesar de ouvirem [s] em posição final de palavra em $\mathrm{PB}$, podem ter notado que, diante de segmento vozeado, a fricativa se realiza como [z], assim como também é realizada como [z] no plural de palavras com término em [s], p. ex., 'me[s]', 'me[z]es'. Desse modo, não se deve descartar a possibilidade de que /z/ esteja como input na interlíngua dos informantes.

Pressupondo-se que /z/ seja então a forma subjacente, o output ótimo realizado com [s] revelaria que nenhuma das duas restrições de fidelidade, IDENTSTEM(voice) ou IDENT(voice), tem prioridade na hierarquia do aprendiz anglófono iniciante: 'ma[s d]epois' viola IDENTSTEM(voice), pela mudança no traço de vozeamento da obstruinte final do radical, portanto, violando também IDENT(voice), e ‘meu[s a]migos’ viola IDENT(voice), como se pode constatar no ranqueamento, em que “:”” indica que não foi escolhido o output ótimo correto pela hierarquia estabelecida.

Uma das propostas que se faz aqui é a de que FiNALDEV tenha sido rerranqueado para a posição dominante nesse primeiro estágio de aquisição do PL2, respondendo pelo não vozeamento da fricativa final. Assim, os outputs ótimos corretos, ou seja, que de fato emergiram na fala dos informantes, ma[s d]epois e meu[s a]migos, seriam selecionados, não havendo erros de ranqueamento, conforme exposto no tableau (23).

(23) Ranqueamento com seleção de output ótimo correto (interlíngua)

FINALDEV >> IDENTSTEM(voice) >> AGREE >> IDENT(voice) >> AGREE FV

\begin{tabular}{|c|c|c|c|c|c|}
\hline $\mathrm{ma} / \mathrm{s} / \mathrm{stem}+/ \mathrm{d} /$ epois & FINALDEV & $\begin{array}{c}\text { IDENTSTEM } \\
\text { (voice) }\end{array}$ & AGREE & $\begin{array}{l}\text { IDENT } \\
\text { (voice) }\end{array}$ & AGREE FV \\
\hline a. ma[s d]epois & & & * & & \\
\hline b. $\mathrm{ma}[\mathrm{z}$ d]epois & $* !$ & $*$ & & $*$ & \\
\hline \multicolumn{6}{|l|}{$\mathrm{meu} / \mathrm{s} /+$ /a/migos } \\
\hline a. meu[s a]migos & & & & & * \\
\hline b. meu[z a]migos & $* !$ & & & $*$ & \\
\hline \multicolumn{6}{|l|}{$\mathrm{ma} / \mathrm{z} /_{\text {stem }}+/ \mathrm{d} /$ epois } \\
\hline a. ma[s d]epois & & $*$ & * & * & \\
\hline b. ma[z d]epois & $* !$ & & & & \\
\hline \multicolumn{6}{|l|}{ meu/z/ + /a/migos } \\
\hline a. meu[s a]migos & & & & $*$ & * \\
\hline b. meu[z a]migos & $* !$ & & & & \\
\hline
\end{tabular}


FINALDEV estando acima das demais restrições responderia pelo não vozeamento da fricativa final, tanto para o input com /s/ quanto para o input com /z/. No primeiro caso, para o input com /s/, FINALDEV seria satisfeito ao custo da violação de AGREE - [sd] é um cluster sem concordância de vozeamento - ou de AGREE FV - [s a] é uma sequência em que a fricativa não concorda em vozeamento com a vogal heterossilábica. No segundo caso, para o input com /z/, FINALDEV é satisfeito ao custo da violação de um maior número de restrições, o output ótimo ‘ma[s d]epois’ viola IDENTSTEM(voice), AgREE e IDENT(voice), e o outro output ótimo ‘meu[s] amigos’ viola IDENT(voice) e AGREE FV, como essas restrições são dominadas por FINALDEV, não interferem na escolha desses outputs como ótimos. A prioridade estaria no não vozeamento final da obstruinte.

O output em [s], tendo /z/ por input, justificaria a posição dominante de FINALDEV na hierarquia. Por outro lado, considerando /s/ como input, um argumento que justificaria [s] como resultante da dominância de FINALDEV, e não de IDENTSTEM(voice), teria por base o fato de que, em dados de aquisição de L1, restrições de marcação dominarem restrições de fidelidade, ranqueamento que poderia estar também exercendo influência na hierarquia de aprendizes anglófonos de PL2 em início de aprendizagem.

Apesar de não ser possível determinar o valor para o traço de vozeamento do input na interlíngua dos informantes, não sendo possível estabelecer se, caso o input seja com [s], a prioridade esteja em IDENTSTEM(voice) ou em FINALDEV, pode-se afirmar que as restrições que militam a favor da concordância de vozeamento entre segmentos adjacentes, AGREE e AGREE FV, são dominadas na hierarquia da interlíngua, independentemente do input.

A posição dominada das restrições da família AGREE resulta, tal como em inglês como L1, na ocorrência de cluster de obstruinte final surda e consoante sonora, p. ex., 'ma[s d]epois’ (cf. inglês this $\operatorname{dog}>$ /ðis/ thi[s d]og 'esse cão'), e na produção da sequência fricativa final surda + vogal, p. ex., 'meu[s a]migos' (cf. less is more > /les/ le[s i]s more 'menos é mais).

Ao se considerar as restrições AGREE e AGREE FV em posição baixa na hierarquia do PL2 por anglófonos, sendo dominadas por FINALDEV, ou mesmo por restrições de fidelidade ao vozeamento subjacente - uma das possibilidade quando se considera /s/ como input -, o ranqueamento desses aprendizes iniciantes de PL2 difere substancialmente do ranqueamento do PB, em que as restrições AGREE e AGREE FV vêm em posição dominante, devendo ser obrigatoriamente satisfeitas.

São então propostos os seguintes ranqueamentos que possam dar conta da ausência de assimilação regressiva de vozeamento pelos informantes: 
(23) Input /s/

i. IDENTSTEM (voice) >> AGREE >> IDENT (voice) >> FINALDEV>> AGREE FV

ii. FINALDEV >> IDENTSTEM (voice) >> AGREE >> IDENT (voice) >> AGREE FV Input /z/

iii. FINALDEV >> IDENTSTEM (voice) >> AGREE >> IDENT (voice) >> AGREE FV

Assume-se que os informantes estejam transferindo a hierarquia do inglês para a interlíngua, mantendo IDENTSTEM como prioritária, tal como ocorre em inglês, de acordo com o ranqueamento estabelecido por Grijzenhout (2000) para o inglês, ou que estejam rerranqueando FINALDEV para uma posição prioritária na hierarquia da interlíngua.

Finalmente, abaixo, em (24), seguem o ranqueamento proposto para o PL2 por anglófonos, em que as restrições AGREE e AGREE FV estão em posição inferior na hierarquia, podendo ser dominadas ou pela restrição de marcação FINALDEV ou pelas restrições de fidelidade IDENTSTEM(voice) e IDENT(voice), assim como as hierarquias para o português e para o inglês.

(24) i. Hierarquia da interlíngua dos informantes

\{FinalDev, IdentStem(voice), Ident(voice)\} >> AgRee, AgReE FV

ii. Hierarquia do português

AgreE, AgreE FV, IDONSLAR >> FINALDEV >> IDENT(voice)

iii. Hierarquia do inglês

IDENTSTEM(voice) $>>$ AGREE $>$ IDENT(voice) $>>$ FINALDEV >> AGREE FV

Assim, a hierarquia dos informantes difere-se da hierarquia do PB, assemelhando-se então à do inglês, no que concerne à posição dominada de AGREE e AGREE FV.

Como não foi determinado se o input dos informantes é em /z/ ou em /s/, não é possível precisar se eles, ao produzirem [s] no output, estariam se utilizando de uma hierarquia que prioriza restrições de fidelidade ao vozeamento do input, o que iria se caracterizar como transferência da L1, ou que prioriza a restrição de marcação que milita a favor do não vozeamento de obstruintes finais, FINALDEV, característica que se constituiria como um exemplo da emergência do não marcado.

No que concerne a padrões de vozeamento de clusters e de obstruintes diante de vogal heterossilábica, FINALDEV não é uma restrição prioritária nem em inglês nem em português. No primeiro, a restrição de fidelidade ao vozeamento do input, IDENTSTEM(voice), vem em posição prioritária; no segundo, AGREE e AGREE FV são as restrições dominantes na 
hierarquia. A posição dominante de FINALDEV no ranqueamento dos informantes refletiria um dado da emergência do não marcado, em que, conforme Broselow et al. (1998), uma restrição obscurecida na L1 do falante passaria a atuar, pelo rerranqueamento, em sua produção em L2.

Apesar de não ser comprovada a emergência do não marcado na produção dos informantes, uma vez que não se pode determinar o valor para o traço de vozeamento do input - somente o input em /z/ poderia assegurar a emergência do não marcado -, o modelo de TO é eficiente ao explicitar a transferência da L1 no que diz respeito à posição dominada de AGREE e AGREE FV no ranqueamento da interlíngua dos informantes.

\subsection{ANÁLISE VIA TEORIA DA OTIMIDADE DA PRODUÇÃO DA NASAL EM POSIÇÃO FINAL E DE FRONTEIRA DE PALAVRA}

Nesta seção, as restrições a serem utilizadas nas análises são apresentadas, bem como os ranqueamentos que governam a nasalidade em coda no $\mathrm{PB}$, no inglês e na interlíngua. $\mathrm{O}$ ponto de partida é um artigo de Bisol (2008), em que a autora, por meio do modelo da TO, formaliza a hierarquia de restrições responsáveis pela produção da sequência VN em português. As análises para o inglês baseiam-se fundamentalmente em Cohn (1993), Kager (1999) e McCarthy e Prince (1995). Ao final, propõe-se uma hierarquia que dê conta da produção da vogal nasal pelos aprendizes anglófonos de PL2 em início do processo de aprendizagem do idioma, que aqui corresponde aos primeiros três meses de residência do aprendiz no Brasil.

\subsubsection{Formalização da hierarquia de restrições para o PB e o inglês}

\subsubsection{A vogal nasal e a vogal nasalizada}

Considera-se vogal nasal uma sequência tautossilábica formada por vogal + arquifonema /N/, esse último realizado como um elemento consonântico [m, n, $\mathrm{n}, \mathrm{n}]$, a depender do ponto de articulação do segmento contíguo, ou como um glide [̃̃, w] (BISOL, 2008; CAGLIARI, 2007; MATTOSO CÂMARA JR., 2007 [1970]). Há ainda autores que consideram a possibilidade de não haver ocorrência de nenhum desses elementos acompanhando a vogal, que poderia ser realizada também como uma vogal nasalizada simples (CAGLIARI, 2007). 
O fato de a nasalidade das vogais do português poder ser tanto fonológica (contrastiva) como alofônica (contextual), enquanto, em inglês, ser observado apenas esse segundo tipo de nasalidade, pode decorrer da diferença de prioridade estabelecida pelas duas línguas para restrições de fidelidade e marcação.

Vale ressaltar que a análise realizada aqui se limita à produção de vogais nasais, como a sequência vogal + /N/ das palavras 'bem' e 'som'. Ditongos nasais, como em 'mão' e ‘capitães’, não são tratados neste trabalho. Quando um glide for acompanhado pelas vogais nasais, elas serão denominadas ditongos nasalizados, de modo a não serem confundidas com ditongos nasais.

É praticamente consensual entre pesquisadores da fonologia do PB e da fonologia do português europeu o pressuposto de que a nasalidade das vogais nasais decorra de um processo de assimilação da nasalidade de /N/ tautossílábico. Será essa hipótese, VN, que servirá de embasamento para a presente análise, desconsiderando-se, portanto, que exista um contraste entre V e Ṽ no nível subjacente em português, mas apenas entre V e VN.

No nível de superfície, no entanto, é aqui levado em consideração que o arquifonema /N/ do português possa assumir as formas de um elemento consonântico, de um glide ou até mesmo, segundo alguns autores, apenas da vogal nasal sem nenhum elemento seguinte, tendo-se em conta que, na variante paulistana do $\mathrm{PB}$, a forma de um glide nasalizado é a mais frequente (FERREIRA NETTO, 2001).

Apesar de Bisol (2008) analisar via TO a realização da vogal nasal do português apenas em posição interna e de final de palavra, assume-se aqui que sua análise possa se aplicar também à posição de fronteira de palavra, uma vez que, nessa posição, a vogal nasal pode ser produzida tal como em posição final e, segundo Cagliari (2007), pode também se assimilar à consoante seguinte, como ocorre em posição interna de palavra.

Em termos de TO, a presença ou ausência do contraste de nasalidade das vogais resulta do conflito entre restrições de fidelidade, que militam a favor da correspondência do traço [nasal] entre a forma de input e a forma de output, e restrições de marcação, que requerem, por exemplo, que vogais não sejam nasais, a não ser que venham acompanhadas de uma consoante nasal adjacente (KAGER, 1999; MCCARTHY; PRINCE, 1995).

Para Bisol (2008), a restrição de fidelidade que permite a correspondência entre a nasalidade do input e do output (1) deve vir em posição elevada na hierarquia do PB, de modo que ocorra contraste entre vogal nasal e vogal oral. 
(1) $\operatorname{MAx}(\mathrm{N})-$ o input /N/ deve ter um correspondente no output (MCCARTHY; PRINCE, 1995)

Com a utilização de MAX (N) no topo da hierarquia, a nasal flutuante /N/ do português deve então adquirir alguma representação na forma de output, fazendo com que /soN/ 'som', por exemplo, não seja realizado foneticamente como [so], contendo apenas uma vogal oral.

Em conflito com a restrição de fidelidade ao traço [nasal], MAX (N), está a restrição universal de marcação que milita contra a ocorrência de vogais nasais nas línguas, expressa em (2).

(2) $\quad$ *V(nasal) - vogais nasais são proibidas (MCCARTHY; PRINCE, 1995)

Maddieson (1984 apud KAGER, 1999, p. 28) ${ }^{20}$ cita alguns motivos pelos quais vogais nasais são universalmente mais marcadas que vogais orais, a saber: 1) a maioria das línguas não possuem vogais nasais, mas possuem vogais orais, 2) línguas que possuem vogais nasais também possuem vogais orais e 3) as línguas podem ter tanto vogais orais quanto nasais, mas não há línguas que possuam apenas vogais nasais.

A partir dessas considerações, apresenta-se aqui uma hierarquia parcial para o PB, baseada em Bisol (2008), em que é demonstrada a superioridade da restrição MAX (N) em relação à restrição *V(nasal).

(3) Ranqueamento parcial referente à produção da vogal nasal (PB)

$\operatorname{MAX}(\mathrm{N})>>* \mathrm{~V}($ nasal $)$

\begin{tabular}{|c|c|c|}
\hline /kaNto/ & $\operatorname{MAX}(\mathrm{N})$ & *V(nasal) \\
\hline a. ['ks̃n.tv] & & * \\
\hline b. ['ks̃u.to] & & * \\
\hline c. ['ka.to] & $* !$ & \\
\hline /boN/ & & \\
\hline a. [bõy] & & $*$ \\
\hline b. [bõ w̃] & & ** \\
\hline c. [bo] & $* !$ & \\
\hline
\end{tabular}

Nota-se no tableau (3) que os candidatos (3c) violam a restrição que milita a favor da correspondência de nasalidade entre input e output, MAX (N), uma vez que esses são constituídos apenas por vogal oral. Ao contrário, os candidatos (3a) e (3b) satisfazem MAX

\footnotetext{
${ }^{20}$ MADDIESON, I. Patterns of Sounds. Cambridge: Cambridge University Press, 1984.
} 
(N) ao conservarem o traço de nasalidade do input, mesmo que, para isso, precisem violar *V(nasal), em posição inferior na hierarquia - nesse ranqueamento, optou-se por incluir duas formas como ótimas, (3a) e (3b), pelo fato de ambas poderem ser encontradas em PB.

Não é característica do inglês a ocorrência de vogais com o traço [nasal] sem que haja uma consoante nasal adjacente, com exceção de alguns poucos casos em posição interna de palavra, por exemplo, [nt] tautossilábico, em que pode ocorrer apagamento da consoante nasal, [sẽnt] $\rightarrow$ [sẽt] sent 'enviado' (COHN, 1993).

O candidato [bõ w̃], dentre os candidatos em (3), dificilmente seria eleito como forma ótima em inglês, língua em que seria preferível a articulação de alguma consoante nasal para que a vogal com o traço [nasal] ocorresse. Em contrapartida, em PB, a articulação de uma consoante nasal adjacente não é necessária. Na variedade paulistana do PB, por exemplo, é comum um glide nasalizado ocupar essa posição.

Interagindo com MAX (N) e *V(nasal), há a restrição que milita contra vogais orais diante de consoantes nasais tautossilábicas, $\mathrm{V}_{\mathrm{ORAL}} \mathrm{N}$, não inclusa no ranqueamento de restrições proposto por Bisol (2008), mas atuante tanto em PB quanto em inglês, já que em ambas as línguas, vogais que estejam diante de uma consoante nasal tautossilábica devem ser nasalizadas.

(4) $\quad \mathrm{V}_{\text {ORAL }} \mathrm{N}$ - antes de nasal tautossilábica, vogais não podem ser orais (MCCARTHY; PRINCE, 1995)

De acordo com Cohn (1993), é comum nas línguas a tendência de nasalizar vogais que antecedem consoantes nasais tautossilábicas. Essa antecipação se deve tanto a aspectos de articulação quanto de percepção. A restrição (4) mostra-se então sensível ao contexto, diferente de *V(nasal), de caráter independente do contexto (KAGER, 1999).

A vogal produzida como oral diante de consoante nasal tautossilábica viola $\mathrm{V}_{\mathrm{ORAL}} \mathrm{N}$. O fato de que em PB e em inglês vogais diante de consoantes nasais serem nasalizadas demonstra que a restrição (4) ocupa uma posição prioritária na hierarquia dos dois idiomas.

Bisol (2008) não considera que existam vogais nasais em português que não sejam acompanhadas por um elemento consonântico ou por um glide. Assim, a autora utiliza-se da restrição BRANCH (N), responsável pela ramificação da nasal (5).

(5) BRANCH $(\mathrm{N})$ - a nasal /N/ deve ser ramificada

A ramificação da nasal deve ocorrer à esquerda e à direita, nasalizando a vogal à esquerda e criando um segmento nasal à direita (BISOL, 2008, p. 5). Formas como ['k̃̃.to] e [kan.to] para 'canto', por exemplo, violariam BRANCH $(\mathrm{N})$, já que, no primeiro caso, há 
apenas nasalização da vogal e, no segundo caso, apenas a articulação da nasal [n], sem a nasalização da vogal. Para que a restrição BRANCH (N) seja satisfeita, é necessário que a ramificação de /N/ se dê nas duas direções, como em [ 'kãn.tu].

Outra restrição inclusa por Bisol na análise da vogal nasal do PB, mas que ocupa uma posição baixa no ranqueamento, sendo facilmente violada, é a restrição que impede a ocorrência de segmento nasal epentético (6).

(6) DEP (N) - segmentos nasais no output devem ter correspondentes no input (MCCARTHY; PRINCE, 1995)

No input, /N/ seria um autossegmento flutuante, uma nasal sem raiz. A inserção de oclusivas nasais no output se caracterizaria, sob essa perspectiva, como epêntese, conforme Bisol (2008). Assim, a restrição (6) proibiria formas como ['kãn.to] e [kan.to], para 'canto', e [bõy] e [bõn], para 'bom’, por exemplo, pois nelas o segmento nasal está articulado.

Ainda como uma das restrições relevantes para a produção da vogal nasal do PB, Bisol (2008, p. 5) adiciona a restrição que milita contra vogais longas, p. ex. ['kã..tu] 'canto', expressa em (7).

(7) No Long VowEL - vogais dominadas por mais de uma mora devem ser evitadas

As vogais longas podem ser retratadas, por exemplo, a partir de dados da aquisição da escrita pelo falante nativo do PB, em que os aprendizes, muitas vezes, escrevem a vogal nasal com duas vogais (BISOL, 2008, p. 7).

A justificativa para a restrição No LONG VOWEL é a de que outputs como ['kã..tø] não violam as duas restrições altas na hierarquia, MAX $(\mathrm{N})$ e BRANCH $(\mathrm{N})$, precisando haver uma restrição específica impedindo que formas desse tipo ocorram.

Segundo Bisol, o que desfavoreceria a produção de uma vogal longa em prol de uma vogal seguida por elemento consonântico ou glide seria uma restrição de reciprocidade, baseada em Goldrick (2000 apud Bisol, 2008, p. 7) ${ }^{21}$ : se uma nasal projeta uma mora, a mora deve estar em correspondência com o segmento nasal. Essa restrição eliminaria ['kz̃:.to] da disputa, já que a mora é transferida para a vogal, alongando-a e deixando de haver a correspondência com o segmento nasal. Em português, vogais longas não são permitidas, mas o fato de essas vogais não violarem BRANCH (N) e MAX (N) torna, por exemplo, ['k̃̃..to] preferível, de acordo com Bisol, às formas ['kz̃.to] e ['kan.to].

Finalmente, tem-se a restrição MAX-IO, que proíbe apagamento, expressa em (8).

${ }^{21}$ GOLDRICK, M. Turbid output representations and the unity of opacity. Proceedings of NELS, n. 30, p. 2311-2245, 2000. 
(8) MAX-IO - todo segmento no input tem um correspondente no output (MCCARTHY; PRINCE, 1995)

A restrição de fidelidade MAX-IO proíbe que segmentos sejam apagados, sendo violada, por exemplo, por uma forma como ['k̃̃.nu] para /kaNto/, pelo apagamento da oclusiva alveolar /t/. Bisol estabelece essa restrição como alta na hierarquia do PB, como se verá a seguir.

Com base no que foi exposto até agora, segue abaixo, em (9), o ranqueamento estabelecido para as formas 'canto' e 'bom' do $\mathrm{PB}$, com base no ranqueamento proposto por Bisol (2008), assim como o tableau a ele referente.

(9) Ranqueamento referente à produção da vogal nasal (PB)

$\operatorname{MAX}(\mathrm{N}), \operatorname{MAX} I O$, BRANCH $(\mathrm{N})>>$ LONG VOWEL $>>$ DEP $(\mathrm{N})>>* V($ nasal $)$

\begin{tabular}{|c|c|c|c|c|c|c|}
\hline /kaNto/ & $\operatorname{MAX}(\mathrm{N})$ & MAX IO & $\begin{array}{c}\text { BRANCH } \\
(\mathrm{N}) \\
\end{array}$ & $\begin{array}{l}* \text { *LONG } \\
\text { VOWEL }\end{array}$ & $\operatorname{DEP}(\mathrm{N})$ & *V(nasal) \\
\hline a. ['ks̃n.tช] & & & & & * & $*$ \\
\hline b. ['k $3 \tilde{y} . t v]$ & & & & & $*$ & * \\
\hline c. ['ka.to] & $* !$ & & & & & \\
\hline d. ['kñ.tv] & & & $* !$ & & & * \\
\hline e. ['kan.tv] & & & $* !$ & & * & \\
\hline 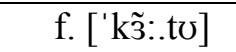 & & & & $* !$ & & $*$ \\
\hline 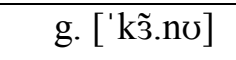 & & $* !$ & & & * & $*$ \\
\hline \multicolumn{7}{|l|}{ /boN/ } \\
\hline a. [bõy] & & & & & * & * \\
\hline b. [bõw] & & & & & & $* *$ \\
\hline c. [bo] & $* !$ & & & & & \\
\hline d. [bõ] & & & $* !$ & & & * \\
\hline e. [boy] & & & $* !$ & & * & \\
\hline f. [bõ:] & & & & $* !$ & & $*$ \\
\hline g. [õn] & & $* !$ & & & * & * \\
\hline
\end{tabular}

Conforme a hierarquia proposta por Bisol (2008), as duas restrições MAX (N) e BRANCH (N) são prioritárias, não podendo ser violadas, candidatos que deixam de produzir o traço nasal são eliminados (9c), assim como os candidatos (9d) e (9e), que violam BRANCH $(\mathrm{N})$, por haver apenas uma ramificação de /N/ nessas formas, ou à esquerda, (9d) ['k̃̃.to] e [bõ], ou à direita, (9e) ['kan.to] e [boy], e não duas, como o preconizado pela restrição. Os 
candidatos (9f) são eliminados da competição por violarem *LONG VowEL, já que o PB não permite vogais longas - ainda assim, esses candidatos se mostram mais harmônicos que os candidatos que violam MAX (N) e BRANCH (N). Os candidatos (9g) são eliminados por apagarem um dos segmentos em correspondência com o output, [t] e [b], respectivamente. Por fim, são escolhidos (9a) e (9b) como outputs ótimos, por não violarem nenhuma das três restrições altas na hierarquia, violam apenas DEP $(\mathrm{N})$ e *V(nasal), para que as demais restrições sejam satisfeitas.

Vale ressaltar que foram inclusos em (9) dois candidatos ótimos para cada input, o que não foi considerado por Bisol. A vogal nasal de /kaNto/ pode ser pronunciada como [з̃n] ou como [з̃̃] pelo falante nativo de PB, havendo assimilação regressiva ou progressiva de ponto de articulação, e, ambas as formas para a vogal nasal de /boN/, [õy] ou [õw], são permitidas na língua.

Conforme visto anteriormente, para Bisol (2008) sempre haverá uma representação de /N/ além da nasalização da vogal, por isso BRANCH (N) revela-se importante. Há estudiosos, como Cagliari (2007), que admitem, dentre as possibilidades de /N/, a realização "pura” da vogal nasal, sem que haja elemento consonântico. Assim, os candidatos (9d), ['k̃̃.to] e [bõ], poderiam surgir como formas de superfície, fato que colocaria BRANCH (N) em posição dominada na hierarquia.

Apesar de a hipótese VN ser geralmente bem aceita na literatura, percebe-se que não há consenso entre os estudiosos sobre a representação de VN na superfície. Bisol (2008, p. 7) defende que muito do que caracteriza VN na subjacência possui efeitos diretos na superfície, como a hipótese de que seja uma sílaba pesada. Como o contexto tratado neste trabalho refere-se à posição final de palavra, em uma variedade que, geralmente, utiliza-se do glide, a restrição BRANCH (N) será tida como prioritária, o que implica na aceitação da ramificação da vogal nasal.

Em relação à nasalidade do inglês, considera-se, em princípio, o ranqueamento parcial de Kager (1999): $* \mathrm{~V}_{\text {ORAL }} \mathrm{N}>>*$ Vnasal $>>$ IDENT-IO (nasal), em que vogais nasais só podem ser produzidas caso estejam diante de consoante nasal. A restrição de fidelidade ao valor da nasalidade da vogal do input, IDENT-IO (nasal), pode ser violada.

O tableau referente ao ranqueamento parcial do inglês proposto por Kager (1999) segue em (10). 
(10) Ranqueamento parcial de restrições que governam a nasalidade das vogais em inglês (KAGER, 1999, p. 31-32)

$* \mathrm{~V}_{\text {ORAL }} \mathrm{N}>>*$ Vnasal $>>$ IDENT-IO (nasal)

\begin{tabular}{|c|c|c|c|}
\hline /sæ̃d/ & $* \mathrm{~V}_{\mathrm{ORAL}} \mathrm{N}$ & *Vnasal & IDENT-IO (nasal) \\
\hline a. [sæd] & & & $*$ \\
\hline b. [sæ̃̃nd] & & $* !$ & \\
\hline \multicolumn{4}{|l|}{ /sænd/ } \\
\hline a. [sænd] & $* !$ & & \\
\hline b. [sæ̃̃nd] & & $*$ & $*$ \\
\hline \multicolumn{4}{|l|}{ /sæ̃̃nd/ } \\
\hline a. [sænd] & $* !$ & & * \\
\hline b. [sæ̃nd] & & * & \\
\hline
\end{tabular}

Nota-se em (10) que, independentemente da forma de input, com ou sem nasalização da vogal, a opção pelo output ótimo, em uma competição envolvendo um candidato formado pela sequência vogal oral + [n] e um candidato formado pela sequência vogal nasalizada + [n], recai sobre esse último candidato. No entanto, se há um candidato sem vogal nasalizada ou sem consoante nasal, como [sæd], ele é selecionado, mesmo que viole IDENT-IO (nasal), restrição baixa na hierarquia.

O que ocorre com a vogal nasalizada do inglês é um caso de variação alofônica ou contextual, a língua não possui contraste entre vogais orais e nasais em nenhuma posição (KAGER, 1999, p. 27). De acordo com Kager, apenas a interação entre restrições de marcação dominando a de fidelidade, como em (10), daria conta do status de nasalidade das vogais do inglês.

Fazendo uso de algumas das restrições utilizadas por Bisol (2008) para o português e das considerações feitas por Kager (1999), é estabelecido aqui um ranqueamento para o inglês, assumindo que, em posição final de palavra, a oclusiva nasal seja especificada, e não um autossegmento flutuante, como em português - há contraste em inglês entre some 'alguns' e sun 'sol', por exemplo, respectivamente, [s $\mathrm{s} \mathrm{m}]$ e $[\mathrm{s} \Lambda \mathrm{n}]$. 
(11) Ranqueamento de restrições que governam a nasalidade das vogais em inglês

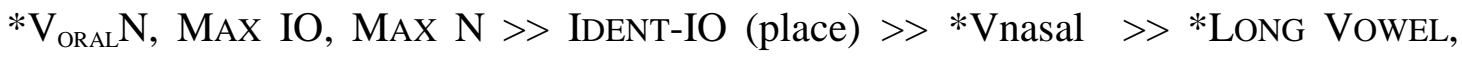
IDENT-IO

\begin{tabular}{|c||c|c|c|c|c|c|c|}
\hline /zen/ & $* \mathrm{~V}_{\text {ORAL }} \mathrm{N}$ & MAX IO & MAX (N) & $\begin{array}{c}\text { IDENT-IO } \\
\text { (place) }\end{array}$ & $*$ Vnasal & $\begin{array}{c}* \text { LONG } \\
\text { VOWEL }\end{array}$ & $\begin{array}{c}\text { IDENT-IO } \\
\text { (nasal) }\end{array}$ \\
\hline \hline a. [zẽy] & & & & $* !$ & $*$ & & $*$ \\
\hline b. [zẽj] & & & & $* !$ & $* *$ & & $*$ \\
\hline c. [zẽn] & & & & & $*$ & & $*$ \\
\hline d. [zẽ] & & $* !$ & & & $*$ & & $*$ \\
\hline e. [zem] & $* !$ & & & $*$ & & & $*$ \\
\hline f. [zẽ:] & & $* !$ & & & $*$ & $*$ & $*$ \\
\hline g. [ze] & & $* !$ & & & & & \\
\hline h. [zed] & & & $* !$ & & & & $*$ \\
\hline
\end{tabular}

As restrições do ranqueamento (11) diferem-se das restrições do ranqueamento (9), propostas por Bisol para a análise das vogais nasais do português, do seguinte modo: a) BRANCH (N) foi retirada, já que não se está lidando com um autossegmento flutuante que precisa se manifestar em duas direções, mas com um segmento já especificado, /n/, b) DEP (N) foi retirado para simplificar a hierarquia, entende-se que essa restrição esteja em posição elevada na hierarquia do inglês, sendo normalmente satisfeita, a língua costuma proibir segmentos epentéticos de modo geral e a produção das oclusivas nasais finais não se constituiria como epêntese, uma vez que é um segmento especificado que se tem no input, e não um arquifonema $/ \mathrm{N} /$, c) por se ter retirado BRANCH $(\mathrm{N})$, acrescentou-se $* \mathrm{~V}_{\mathrm{ORAL}} \mathrm{N}$, para que se possa dar conta do espraiamento da nasalidade à esquerda, d) foi acrescentada a restrição IDENT-IO (place), que milita a favor da fidelidade de ponto de articulação entre input e output, garantindo que [n], e não [m], por exemplo, seja produzido.

A restrição $* \mathrm{~V}_{\mathrm{ORAL}} \mathrm{N}$, prioritária na hierarquia, exclui (11e) da competição. Também prioritária na hierarquia, a restrição que milita contra apagamento, MAX-IO, exclui os candidatos que apagam a consoante nasal $(11 \mathrm{~d}, \mathrm{f}, \mathrm{g})$. Em seguida IDENT-IO (place) garante que os candidatos, cujo elemento nasal se diferencia da forma de input, sejam eliminados da competição (11a, b) - essa restrição vem em posição inferior, uma vez que pode ser violada em casos de assimilação com a obstruinte em início de palavra seguinte, como se verá a seguir. O candidato a output ótimo (11c) vence, ao custo de violar essa restrição *Vnasal, em posição inferior na hierarquia. 
Com a utilização de ${ }^{*} \mathrm{~V}_{\text {ORAL }} \mathrm{N}$ e IDENT-IO (place) garante-se que a vogal tenha nasalidade e que uma consoante nasal seja articulada à sua direita, com a diferença em relação à BRANCH (N) estando no fato de que essa nasal tenha o mesmo ponto de articulação da nasal subjacente, já especificada. Ademais a ordem das restrições $* \mathrm{~V}_{\mathrm{ORAL}} \mathrm{N}$, $*$ Vnasal e IDENT-IO (nasal) segue tal como em Kager (1999): ${ }^{*} \mathrm{~V}_{\text {ORAL }} \mathrm{N}>>$ *Vnasal $>>$ IDENT-IO (nasal).

\subsubsection{Assimilação de ponto de articulação das nasais}

Em PB, a nasal assimila o ponto de articulação da obstruinte seguinte, caso essa não seja contínua. Para Bisol (2008) e Cagliari (2007), se a consoante seguinte for contínua, a tendência é de que a assimilação se dê com a vogal precedente, tal como ocorre em posição final de palavra. Em posição de fronteira de palavra, de acordo com Cagliari (2007), pode a assimilação com a consoante seguinte também pode ocorrer.

Para dar conta da assimilação da nasal com a consoante seguinte, Bisol (2008) utilizase de uma restrição de marcação que milita a favor da concordância de ponto de articulação entre input e output, "IDENTCC (place)” - aqui renomeada para “AGREE (CC)”, de modo que não seja tida como uma restrição de fidelidade/identidade ao ponto de articulação.

(12) AGREECC - uma sequência de consoantes deve ser idêntica em ponto de articulação

$\mathrm{O}$ arquifonema /N/ é licenciado como um segmento em coda em PB pela atuação de AGREECC (place) - em que CC é a abreviação de cluster constraint. Essa restrição impede, por exemplo, a forma ['kz̃y.to] 'canto', pois [y] e [t] não compartilham o mesmo ponto de articulação, o primeiro é velar e o segundo, alveolar. A forma ['kz̃n.to], por outro lado, satisfaria essa restrição, [n] e [t] são homorgânicos em ponto de articulação.

A partir de AgREECC (place), surge uma restrição mais específica, (13), a qual milita a favor do compartilhamento de ponto de articulação entre elementos que possuam o mesmo traço de continuidade.

(13) AgreEC $\mathrm{C}_{\mathrm{i}} \mathrm{C}_{\mathrm{i}}$ - uma sequência de segmentos idênticos para o traço [contínuo] deve também possuir segmentos idênticos em ponto de articulação

A forma ['kãy.to] 'canto' violaria $\operatorname{AgREEC}_{\mathrm{i}} \mathrm{C}_{\mathrm{i}}$ (place): a nasal e [t] são [-contínuo], sendo assim deveriam compartilhar o mesmo ponto de articulação: a nasal assimilando-se ao ponto de articulação de [t] e manifestando-se como [n]. 
Para dar conta da assimilação da nasal ao ponto de articulação da vogal precedente, o que geralmente ocorre quando a consoante seguinte é fricativa ou quando /N/ está em final de palavra, Bisol (2008) utiliza-se da restrição AGREE (VC), expressa em (14).

(14) AGREE (VC) - o segmento nasal em posição de coda deve concordar em ponto de articulação com a vogal precedente

A forma ['dz̃n.se] 'danço', por exemplo, violaria AGREe (VC), uma vez que [n] não concorda em ponto de articulação com a vogal precedente; ['dãy.se], por sua vez, satisfaria essa restrição, a nasal velar [y] concorda com a vogal central baixa /a/.

Em (15) segue o ranqueamento, de acordo com o proposto por Bisol, para as formas 'canto’ e ‘dança'.

(15) Assimilação de ponto de articulação das nasais (PB) com dominação de $A_{G R E E C} C_{i}$

AgREEC $_{\mathrm{i}} \mathrm{C}_{\mathrm{i}}$ >> Agree (VC) >> AGREECC

\begin{tabular}{|c|c|c|c|}
\hline /kaNto/ & AGREEC $_{\mathrm{i}} \mathrm{C}_{\mathrm{i}}$ & AGREE (VC) & AGREECC \\
\hline a. ['ks̃n.tu] & & * & \\
\hline b. ['k̃̃y.to] & $* !$ & & * \\
\hline /daNsa/ & & & \\
\hline a. ['dz̃n.se] & & $* !$ & \\
\hline b. ['dz̃y.se] & & & * \\
\hline
\end{tabular}

No caso de /N/ diante de obstruinte oclusiva, como no primeiro input, /kaNto/, o output selecionado como ótimo é o (15a), em que há concordância entre os segmentos do cluster [nt], por se tratarem de dois segmentos oclusivos. A restrição que milita a favor da concordância entre vogal e consoante, AgREE (VC), é violada de modo que AGREEC $\mathrm{C}_{\mathrm{i}}$ seja satisfeita. O candidato [' $k \tilde{y}$.tซ] é eliminado por não satisfazer $\mathrm{AGREEC}_{\mathrm{i}} \mathrm{C}_{\mathrm{i}}$ (place): apesar dos segmentos da sequência serem ambos oclusivos, houve, por esse candidato, concordância entre a nasal e a vogal antecedente.

Diferentemente de /kaNto/, no input /daNsa/ não há uma sequência de duas obstruintes que compartilham do mesmo traço de continuidade, /N/ é oclusivo e /s/, contínuo. Assim a tendência é que a concordância da nasal se estabeleça com a vogal anterior, havendo assimilação progressiva de ponto articulação. Em (15), o candidato a output ['dãn.se] é eliminado por concordar em ponto de articulação com a fricativa seguinte e não com a vogal anterior. Assim, ['dãy.se] é escolhido como output ótimo, ainda que viole a restrição AGREECC, baixa na hierarquia. 
É importante ressaltar aqui que a assimilação progressiva, envolvendo a nasal e a vogal que a antecede, pode resultar em sequências não homorgânicas, formadas pela palatal [n] (resultante da assimilação com [e, i] precedentes) + segmento não homorgânico qualquer, p. ex. be[n t]arde, ou pela velar [n] (resultante da assimilação com [a, o, u] precedentes) + segmento não homorgânico qualquer, p. ex. 'bo[n d]ia'. As nasais oclusivas [m, n], no entanto, não surgiriam por assimilação progressiva, a não ser, para alguns falantes, pela articulação da bilabial [m] quando a vogal precedente é posterior fechada, como em 'rum' [xum].

Para a assimilação progressiva de ponto de articulação da nasal, como em ['kz̃y.tซ], em que a nasal assimila o ponto de articulação velar da vogal (CAGLIARI, 2007), a restrição Agree (VC) dominaria as restrições AgreeCC e AgreeC $\mathrm{C}_{\mathrm{i}}$, como expresso em (16).

16) Assimilação de ponto de articulação das nasais (PB) com dominação de AGREE (VC) Agree (VC) >> AGReEC $\mathrm{C}_{\mathrm{i}}$, AgreeCC

\begin{tabular}{|c|c|c|c|}
\hline /kaNto/ & AGREE (VC) & AGREEC $_{\mathrm{i}} \mathrm{C}_{\mathrm{i}}$ & AGREECC \\
\hline a. ['kz̃n.to] & $* !$ & & \\
\hline b. ['k̃̃â.to] & & $* !$ & * \\
\hline /daNsa/ & & & \\
\hline a. ['dz̃n.se] & $* !$ & & \\
\hline b. ['d $\tilde{3} y . s e]$ & & & * \\
\hline
\end{tabular}

Nota-se que, pelo ranqueamento em (16), a nasal concorda em ponto de articulação com a vogal antecedente, resultando nos outputs ótimos (16b), independentemente de a obstruinte seguinte ser fricativa ou oclusiva. Essa realização da nasal reflete a posição elevada que AgreE (VC) possui nessa hierarquia.

De acordo com Cagliari (2007), a assimilação de ponto de articulação das nasais pode se estender também para a posição de fronteira de palavra. Nesse caso, tanto o ranqueamento em (16) quanto o ranqueamento em (15) se fazem possíveis.

Em (17) e (18) seguem, para a posição de fronteira de palavra, os mesmos ranqueamentos propostos em (15) e (16), respectivamente. 
(17) Assimilação de ponto de articulação das nasais (PB) com dominação de $\operatorname{AGREE}_{\mathrm{i}} \mathrm{C}_{\mathrm{i}}$ para a posição de fronteira de palavra

AGREEC $_{\mathrm{i}} \mathrm{C}_{\mathrm{i}}$ >> Agree (VC) >> AGREECC

\begin{tabular}{|c||c|c|c|}
\hline be/N/ tarde & AGREEC $_{\mathrm{i}} \mathrm{C}_{\mathrm{i}}$ & AGREE (VC) & AGREECC \\
\hline \hline a. be[n t]arde & & $*$ & \\
\hline b. be[n t]arde & $* !$ & & $*$ \\
\hline \hline be/N/ cedo & & & \\
\hline \hline a. be[n s]edo & & $* !$ & $*$ \\
\hline b. be[n s]edo & & & \\
\hline
\end{tabular}

No tableau acima, o output ótimo 'be[n t]arde’ é escolhido por não violar AGREEC $_{\mathrm{i}} \mathrm{C}_{\mathrm{i}}$, mesmo que, para isso, tenha que violar a restrição mais baixa AGREE (VC). Para o outro input, 'be/N/ cedo', o candidato 'be[n s]edo' é escolhido por não violar AGREE (VC), por sua vez, concordando com a vogal antecedente, e não com a fricativa seguinte.

Em posição final de palavra, parece ser mais comum em PB a assimilação com a vogal antecedente, i. e. o ranqueamento em que AGREE (VC) constitui-se como restrição prioritária, o que também propicia a manifestação do glide, conforme se pode verificar em (18).

(18) Assimilação de ponto de articulação das nasais (PB) com dominação de AGREE (VC)

AgreE (VC) >> IDENTCC (place), IDENTCC (place)

\begin{tabular}{|c|c|c|c|}
\hline be/N/ tarde & AGREE (VC) & AGREEC $_{\mathrm{i}} \mathrm{C}_{\mathrm{i}}$ & AGREECC \\
\hline a. be[n t]arde & $* !$ & & \\
\hline b. be[n t]arde & & $*$ & * \\
\hline \multicolumn{4}{|l|}{ c. be[j̃ t]arde } \\
\hline \multicolumn{4}{|l|}{ be/N/ cedo } \\
\hline a. be[n s]edo & $* !$ & & \\
\hline b. be[n s]edo & & & * \\
\hline c. be[j s]edo & & & \\
\hline
\end{tabular}

São escolhidos como outputs ótimos os candidatos (18b, c), que, por sua vez, não violam AGREE (VC), concordando em ponto de articulação com a vogal [e] precedente.

Presume-se haver antes de AGREE (VC) uma restrição que resulte na escolha pela forma com o glide no português paulistano, o que pode ser governado pela restrição NoNHEAD MoRA, em que se tem obediência à escala de sonoridade. Do pico silábico para a coda, 
é menos harmônico uma consoante nasal suceder a vogal do que um glide sucedê-la, esse último mais próximo da vogal em sonoridade.

Assim, pode-se estabelecer o ranqueamento em (19) para a opção pelo glide, e não pela consoante nasal em posição final.

(19) Ranqueamento responsável pela seleção do glide no português paulistano

$(* \mu$ Obstruent $)>>* \mu$ Nasal $>>(* \mu$ Liquid $)>>* \mu$ High Vowel

\begin{tabular}{|c||c|c|}
\hline /boN/ & ${ }^{*} \mu$ Nasal & ${ }^{*} \mu$ High Vowel \\
\hline \hline a. [bõw] & & $*$ \\
\hline b. [bõy] & $* !$ & \\
\hline \hline /beN/ & & \\
\hline \hline a. [bẽj] & & $*$ \\
\hline b. [bẽn] & $* !$ & \\
\hline
\end{tabular}

Os candidatos (19a), constituídos pelo glide, são então selecionados como outputs ótimos pela hierarquia estabelecida. A restrição inferior na hierarquia * $\mu$ High Vowel é violada em favor da restrição mais alta na hierarquia $*_{\mu}$ Nasal - ainda em posição mais elevada na hierarquia estaria $*_{\mu}$ Obstruent, que proíbe obstruintes em coda. Esse ranqueamento dá conta da manifestação de /N/ para os dialetos em que há preferência pelo glide em posição final.

No que concerne ao status da consoante nasal em fronteira de palavra no inglês, pode haver fidelidade à forma subjacente, como no ranqueamento proposto em (20) ou, na fala concatenada, assimilação com a obstruinte seguinte - o que ocorre com mais frequência quando a nasal subjacente é /n/ -, como no ranqueamento proposto em (21). As restrições aqui utilizadas são as mesmas utilizadas por Bisol na análise das vogais nasais do PB, com exceção de IDENTPLACE IO.

Ressalta-se que $\mathrm{AGREEC}_{\mathrm{i}} \mathrm{C}_{\mathrm{i}}$ não é restrição relevante em inglês, podendo vir em qualquer posição na hierarquia - além de poder concordar com a oclusiva seguinte, a nasal pode igualmente concordar com a fricativa seguinte, p. ex. te[m] forks 'dez garfos', em que a nasal torna-se labiodental. 
(20) Ausência de assimilação de ponto de articulação das nasais (inglês) com dominação de IDENTPLACE IO para a posição de fronteira de palavra

IDENTPlace IO >> AgreeC $\mathrm{A}_{\mathrm{i}}$, AgreeCC >> AgreE (VC)

\begin{tabular}{|c||c|c|c|c|}
\hline $\mathrm{i} / \mathrm{n} /$ Paris & IDENTPLACE IO & AGREE $\mathrm{C}_{\mathrm{i}} \mathrm{C}_{\mathrm{i}}$ & AGREECC & AGREE (VC) \\
\hline \hline a. i[m P]aris & $* !$ & & $*$ & $*$ \\
\hline b. i[n P]aris & $* !$ & $*$ & $*$ & $*$ \\
\hline c. i[n P]aris & & $*$ & $*$ & $*$ \\
\hline \hline te/n/ grapes & & $*$ & $*$ & $*$ \\
\hline b. te[n g]rapes & & $*$ & & $*$ \\
\hline c. te[n g]rapes & $* !$ & & & $*$ \\
\hline
\end{tabular}

No ranqueamento em (20), são excluídos os candidatos que violam a restrição prioritária na hierarquia, IDENTPLACE IO, a qual milita a favor da correspondência entre input e output no que concerne ao ponto de articulação do segmento. São então escolhidos os candidatos i[n] Paris 'em Paris' e te[n] grapes 'dez uvas', os quais são fiéis ao ponto de articulação alveolar da forma subjacente /n/. As restrições pertencentes à família AGREE são violadas pelos candidatos ótimos.

Em (21) abaixo, há concordância de ponto de articulação no cluster heterossilábico, característica que pode ocorrer em inglês na fala concatenada, rápida e sem pausa (GIMSON; CRUTTENDEN, 2008).

(21) Assimilação de ponto de articulação das nasais (inglês) com dominação de AGREECC para a posição de fronteira de palavra - fala concatenada

AgreeCC, AgreeC $\mathrm{C}_{\mathrm{i}}>>$ IdENTPlaCe $>>$ Agree (VC)

\begin{tabular}{|c||c|c|c|c|}
\hline $\mathrm{i} / \mathrm{n} /$ Paris & AgreEC $\mathrm{C}_{\mathrm{i}}$ & AgreECC & $\begin{array}{c}\text { IDENTPLACE } \\
\text { IO }\end{array}$ & AgReE (VC) \\
\hline \hline a. $\mathrm{i}[\mathrm{m}$ P]aris & & & $*$ & $*$ \\
\hline b. $\mathrm{i}[\mathrm{n}$ P]aris & $* !$ & $*$ & & \\
\hline \hline te/n/ grapes & & & & \\
\hline \hline a. te[n g]rapes & & $* !$ & & $*$ \\
\hline b. te[n g]rapes & & $*$ & & \\
\hline
\end{tabular}

O ranqueamento (21), com a dominação das restrições AGREEC $\mathrm{C}_{\mathrm{i}}$ e AGREECC, permite que, na fala concatenada, haja concordância entre os elementos do cluster 
heterossilábico. Assim, os candidatos $i[\mathrm{~m}$ P]aris e te[y g]rapes são selecionados como outputs ótimos, por, satisfazerem a essas restrições de concordância de ponto de articulação, ao contrário dos candidatos (21b), que as violam.

\subsubsection{Formalização da hierarquia de restrições para a interlíngua}

Em português, conforme visto, as consoantes nasais [m, n] não ocorrem em posição final de palavra, a não ser diante de palavra iniciada por consoantes que lhes sejam homorgânicas em ponto de articulação, ou seja, por consoante bilabial ou alveolar, respectivamente, ou, no caso da bilabial [m], no contexto restrito que sucede vogal posterior fechada.

Dez informantes desta pesquisa, em dado momento de sua fala, produziram as oclusivas nasais [m, n] em posição final de palavra, p. ex. 'be[m]' e 'si[n]', ou de fronteira de palavra diante de segmento consonantal não homorgânico ou vocálico, p. ex. 'te[m d]ois' e 'be[m a]gora'.

O principal fator selecionado como relevante para a produção da oclusiva nasal [m] não houve estabelecimento do peso relativo para a oclusiva nasal [n], por conta do baixo númento de ocorrências - foi o tempo de residência do informante no Brasil, tendo por pesos relativos: .97 (3 meses), .19 (2-3 anos), .14 (9-11 anos) e, contrariamente a ordem decrescente de produção da oclusiva, .59 (20-31 anos).

Nota-se que a produção da oclusiva nasal [m] pelos informantes diminui bruscamente após o início da aprendizagem do PL2 - primeiros três meses de residência no país -, no entanto, são ainda registradas ocorrências na produção de falantes mais experientes residentes no país por mais de 20 anos.

Pressupõe-se aqui que os informantes estejam se utilizando da seguinte estratégia para a realização da vogal nasal do PB: inserir uma consoante nasal para que a vogal nasal, obedecendo a restrição $* \mathrm{~V}_{\mathrm{ORAL}} \mathrm{N}$, possa ser produzida.

A produção da oclusiva nasal é também observada em empréstimos linguísticos do francês para o inglês, por exemplo. Paradis e Prunet (2000) verificaram que, por conta da dificuldade com a vogal nasal do francês, os empréstimos provenientes desse idioma para o inglês geralmente passam por uma adaptação fonético-fonológica pelos falantes anglófonos (em seu estudo, canadenses), p. ex. coupon [kupan], crouton [k.rutan], cancan [kænkæn], os quais são realizados com a produção da oclusiva nasal alveolar em posição final de sílaba. 
No caso dos aprendizes anglófonos de PL2, a escolha da oclusiva bilabial, e não da oclusiva alveolar, provavelmente advém da influência da escrita. Todos os informantes são letrados e possuem acesso à escrita em língua portuguesa.

Para a realização da vogal nasal, nessa primeira etapa de aprendizagem do idioma, hipotetiza-se que os aprendizes estejam se utilizando da mesma hierarquia de restrições do inglês, uma vez que, nesse sistema linguístico, consoantes nasais em coda diante de segmento não homorgânico são licenciadas.

A partir do ranqueamento estabelecido para o inglês, e pressupondo-se que os informantes tenham estabelecido $/ \mathrm{m} /$ como forma subjacente, segue abaixo a proposta de ranqueamento que resulta na produção da consoante nasal final pelo aprendiz anglófono em seu primeiro estágio de aquisição do PL2.

(22) Ranqueamento estabelecido para a interlíngua dos informantes com relação à vogal nasal

$* \mathrm{~V}_{\text {ORAL }} \mathrm{N}$, MAX IO, MAX $(\mathrm{N})>>$ IDENT-IO (place) $>>$ Vnasal $>>$ * LONG VoweL, IDENT-IO

\begin{tabular}{|c||c|c|c|c|c|c|c|}
\hline /bem/ & $* \mathrm{~V}_{\mathrm{ORAL}} \mathrm{N}$ & $\mathrm{MAX}$ IO & $\mathrm{MAX}(\mathrm{N})$ & $\begin{array}{c}\text { IDENT-IO } \\
\text { (place) }\end{array}$ & $*$ Vnasal & $\begin{array}{c}* \text { LONG } \\
\text { VOWEL }\end{array}$ & $\begin{array}{c}\text { IDENT-IO } \\
\text { (nasal) }\end{array}$ \\
\hline \hline a. [bẽy] & & & & $* !$ & $*$ & & \\
\hline b. [bẽj] & & & & $* !$ & $* *$ & & \\
\hline ซ.c. [bẽm] & & & & & $*$ & & \\
\hline d. [bẽ] & & $* !$ & & & $*$ & & \\
\hline e. [bem] & $* !$ & & & $*$ & & & \\
\hline f. [bẽ:] & & $* !$ & & & $*$ & $*$ & \\
\hline g. [be] & & $* !$ & & & & & \\
\hline h. [beb] & & & $* !$ & & & & $*$ \\
\hline
\end{tabular}

Candidatos que violam as restrições prioritárias ${ }^{*} \mathrm{~V}_{\text {ORAL }} \mathrm{N}$, MAX IO e MAX (N), não realizando a nasalização da vogal diante de consoante nasal ou apagando a consoante nasal, são eliminados. Assim, como na hierarquia do inglês, é escolhido o output que não viola IDENT-IO (place), mas, para isso, tendo que violar *Vnasal, restrição baixa na hierarquia.

IDENT-IO (place) está em posição inferior às restrições prioritárias para responder a casos de assimilação que, embora não sejam comuns nessa primeira etapa de aprendizagem do PL2, por poderem ser violadas na hierarquia do inglês (na fala rápida, sem pausa), podem, eventualmente, também vir a serem dominadas na interlíngua. 
Abaixo segue o ranqueamento para o contexto de fronteira de palavra, em que a nasal está diante de consoante ou vogal, assumindo-se que, como o input é a bilabial /m/, segmento menos suscetível a assimilar o ponto de articulação da obstruinte seguinte, não haverá, na interlíngua dos informantes, assimilação com a consoante seguinte, pelo menos nessa primeira etapa de aprendizagem do PL2.

(23) Ausência de assimilação de ponto de articulação das nasais com dominação de IDENTPLACE IO para a posição de fronteira de palavra (interlíngua)

IdentPlace IO >> AgreeC $\mathrm{A}_{\mathrm{i}}$, AgreeCC >> Agree (VC)

\begin{tabular}{|c|c|c|c|c|}
\hline $\mathrm{u} / \mathrm{m} /$ ano & IDENTPLACE IO & AGREEC $_{i} C_{i}$ & AGREECC & AgREE (VC) \\
\hline a. u[n a]no & $* !$ & & & * \\
\hline b. u[y a]no & $* !$ & * & * & \\
\hline c. u[m a]no & & * & * & $*$ \\
\hline \multicolumn{5}{|l|}{$\mathrm{e} / \mathrm{m} /$ casa } \\
\hline a. e[m k]asa & & $*$ & * & * \\
\hline b. e[n k]asa & $* !$ & $*$ & $*$ & \\
\hline c. e[n k]asa & $* !$ & & & * \\
\hline
\end{tabular}

Nota-se em (23), a importância dada à manutenção do ponto de articulação bilabial do input, representada pela prioridade da restrição IDENTPLACE IO na hierarquia. Candidatos que produzem a consoante nasal como alveolar $[\mathrm{n}]^{22}$, velar [n] ou palatal [n] são eliminados, sendo selecionados como outputs ótimos os candidatos que preservam [m] (‘u[m] ano’ e 'e[m] casa'), ao custo de violarem as restrições de concordância em ponto de articulação com o segmento adjacente (AGREeC $C_{i} C_{i}$, AGreECC e AGREe (VC)), em posição inferior na hierarquia.

Pode-se então afirmar que, no que concerne à realização das sequências /aN/, /eN/, /iN/, /oN/ e /uN/, os aprendizes anglófonos de PL2, no início de sua aprendizagem, adotam a hierarquia de restrições do inglês, a qual, ao mesmo tempo que milita a favor da correspondência entre input e output, coloca também como prioritária a restrição de marcação que impede vogais orais diante de segmentos nasais. Disso resulta a emergência de um padrão não marcado, em que uma vogal apenas possui o traço [nasal] se estiver diante de uma consoante nasal plenamente articulada na forma de superfície.

\footnotetext{
${ }^{22}$ Assume-se aqui que outputs ótimos com nasais alveolares têm por input também uma nasal alveolar.
} 
O modelo linguístico proposto pela TO é então bem-sucedido em tornar explícito o envolvimento entre processos de transferência de L1 e de marcação no que concerne à realização da vogal nasal pelo aprendiz iniciante de PL2 nativo de língua inglesa. 


\section{CONCLUSÃO}

Este estudo tratou da descrição e análise via Teoria da Otimidade (TO) (MCCARTHY; PRINCE, 1995; PRINCE; SMOLENSKY, 1993) de dois aspectos recorrentes da fonologia do PL2 por aprendizes anglófonos: a ausência de vozeamento da fricativa alveolar final diante de segmento sonoro e a produção das oclusivas nasais [m, n] em posição final e de fronteira de palavra.

O processo de assimilação regressiva de vozeamento do português, em que a fricativa /s/ em posição final de sílaba adquire o traço [+sonoro] do segmento a sua direita, não foi observado em dado momento da fala dos 11 informantes desta pesquisa, e a realização de [m, n] finais diante de pausa ou de segmento não homorgânico, em substituição à vogal nasal do português, foi observada em dado momento da produção de 10 informantes.

Apesar de o tempo de residência no Brasil ter se mostrado como o fator mais significativo para a assimilação regressiva de vozeamento, bem como para a produção da vogal nasal do português, sem que houvesse a articulação de [m, n] diante de pausa ou de segmento não homorgânico, dados variáveis também puderam ser observados na produção de falantes mais experientes, com tempo de residência no país superior a 20 anos.

A ocorrência de desvios em estágios mais avançados do processo de aquisição aponta para a dificuldade que os falantes têm para a aquisição plena dos dois fenômenos. Essa dificuldade pode advir de processos de transferência de L1 e de marcação, mais influentes em estágios iniciais do processo de aquisição de L2, mas que continuariam a atuar em estágios posteriores (ECKMAN, 1987; MAJOR, 1987, 2001).

Buscou-se, neste trabalho, mostrar a interação entre processos de transferência de L1 e de marcação a partir dos dados de fala dos informantes em seu primeiro estágio de aquisição do português como segunda língua (PL2) - tido aqui como o período que compreende os primeiros três meses de residência no Brasil -, utilizando-se para isso do modelo baseado em restrições proposto pela TO.

De acordo com Hancin-Bhatt (2008), pela TO, é possível identificar o estágio inicial de aquisição da L2 pelo aprendiz, uma vez que o modelo é capaz de explicitar a interação entre efeitos de marcação, os quais, eventualmente, podem emergir na gramática da interlíngua, e efeitos de transferência da L1.

No que concerne à ausência de assimilação regressiva de vozeamento, constatou-se que, de fato, ocorre transferência do ranqueamento de restrições do inglês para o PL2 por 
anglófonos. Os aprendizes realizam sequências de obstruintes e de obstruinte + vogal que possuem traços divergentes para vozeamento, p. ex. 'o[s] dois', 'ma[s] eles', o que demonstra que as restrições da família de AGREE (voice) (AGREE e AGREE FV) são dominadas na hierarquia da interlíngua, sendo, portanto, violadas, tal como ocorre em inglês.

No entanto, ao assumir /s/ como forma subjacente para a fricativa alveolar final, não é possível determinar se ocorre também a emergência de um padrão não marcado, representado pela dominância da restrição que milita a favor da realização surda de obstruintes em posição final de sílaba (e de palavra), FinALDEv, ou se há transferência plena da hierarquia do inglês, em que as restrições de fidelidade que militam a favor da correspondência de vozeamento entre input e output (IDENTSTEM e IDENT (voice)) estão em posição dominante. Tendo /s/ por input, tanto a prioridade de FINALDEV quanto a de restrições de fidelidade ao vozeamento subjacente resultariam na contraparte surda da fricativa como forma de output.

Caso tenha sido /z/ a forma de input da interlíngua dos informantes, o output em [s] justificaria a posição prioritária de FINALDEV, atestando então a emergência do não marcado na interlíngua desses falantes, uma vez que, em inglês, a atuação da restrição FINALDEV poderia estar obscurecida por restrições mais altas na hierarquia.

Na análise da ausência de assimilação regressiva de vozeamento na interlíngua, o desconhecimento da forma de input para a fricativa, se [-sonoro] ou [+sonoro], resulta na indefinição de parte do ranqueamento da interlíngua do aprendiz anglófono iniciante, em relação ao padrão de vozeamento de obstruintes finais. No entanto, constata-se, ainda que parcialmente, a transferência da hierarquia da L1, em que AGREE e AGREE FV são dominadas.

Pelo princípio da Riqueza de Base, qualquer forma para input seria possível, uma vez que a TO, em sua versão standard, opera com restrições no nível do output: independentemente do input, seria eleito o mesmo output ótimo por meio de dado ranqueamento de restrições (SMOLENSKY, 1996). No entanto, no que concerne a processos de aquisição, faz-se necessário o conhecimento da forma de input para a maior precisão na formalização das hierarquias.

Ao contrário da indeterminação do traço de vozeamento para a fricativa alveolar final na interlíngua dos informantes, no que se refere à produção das oclusivas nasais [m, n] em posição final e de fronteira de palavra, tornou-se possível o estabelecimento da forma de input.

Em inglês, as oclusivas nasais [m, n] são licenciadas em coda final, ainda que estejam diante de segmento não homorgânico. Essas oclusivas são permitidas nesse contexto linguístico por conta da posição dominada de AgreeC $_{\mathrm{i}} \mathrm{C}_{\mathrm{i}}$, AgreeCC e AgreE (VC) na 
hierarquia do idioma. Em português, as restrições que militam a favor da concordância de ponto de articulação da nasal com segmentos adjacentes vêm, no entanto, em posição prioritária na hierarquia. Assume-se que os aprendizes anglófonos estejam se utilizando, em sua interlíngua, da hierarquia de restrições do inglês - referente à fala não concatenada -, em que a fidelidade ao ponto de articulação, representada pela restrição IDENTPLACE IO, vem em posição dominante.

A emergência de um padrão não marcado decorreria da inserção das oclusivas nasais [m, n] para a realização da vogal nasal, tida como forma universalmente mais marcada que a vogal oral. Os aprendizes iniciantes, presumivelmente, estabeleceram /m/ como forma de input para a nasal em coda do PB - provavelmente por influência da escrita - e são então fiéis a essa forma. Essa fidelidade ao ponto de articulação da nasal, porém, envolve também um fenômeno de marcação, visto que, propõe-se aqui, a articulação da consoante nasal resulta na maior facilidade em se produzir a nasalidade da vogal.

No que concerne ao status da nasalidade em coda na interlíngua de aprendizes anglófonos de PL2, o modelo da TO foi então capaz de explicitar processos de transferência de L1 e de marcação. A transferência da hierarquia da L1 foi plena e fenômenos de marcação, como o que decorre da impossibilidade em se produzir uma vogal nasal sem uma consoante nasal contígua passam a atuar na hierarquia do primeiro estágio da interlíngua do aprendiz, tornando-se possível sua explicitação pelo modelo de TO.

Os dados descritivos revelaram que a produção das formas-alvo correlaciona-se, fundamentalmente, com o tempo de residência do informante no país, embora persista a variação mesmo em estágios posteriores de aquisição. Esse fato pode servir de encaminhamento para pesquisas futuras, em que, a partir de um corpus mais robusto de análise, leve-se em conta a variação e o rerranqueamento de restrições no decorrer do processo de aprendizagem - tarefa a ser executada por algoritmos de aprendizagem (BOERSMA, 1997; BOERSMA; HAYES, 2001; TESAR; SMOLENSKY, 1996, 2000).

Torna-se clara a vantagem da TO, em relação a outros modelos de análise linguística em explicitar fenômenos de L2 até então com uma abordagem formal mínima. A transferência de L1 e processos de marcação são, desde há muito, considerados intrínsecos à produção em L2, mas, seguindo Hancin-Bhatt (2008), sua interação apenas vem a receber uma explicação direta e "elegante” a partir do modelo da TO standard e de seus desdobramentos. 


\section{REFERÊNCIAS}

ALBANO, E. et al. Segment Frequency and Word Structure in Brazilian Portuguese. In: INTERNATIONAL CONGRESS OF PHONETIC SCIENCES, XIIIth, 1995, Stockholm. Proceedings... Stockholm: Stockholm University, 1995. v. 3, p. 346-349.

ALVES, U. A aquisição das sequências finais de obstruintes do inglês (L2) por falantes do Sul do Brasil: análise via Teoria da Otimidade. 2008. 335 f. Tese (Doutorado em Letras)

- Pontifícia Universidade Católica do Rio Grande do Sul, Porto Alegre, 2008.

ARCHANGELI, D. Introducing Optimality Theory. Annual Review of Anthropology, v. 28, p. 531-552, 1999. Disponível em: <http://www.jstor.org/stable/223405>. Acesso em: 16 abr. 2011.

Optimality Theory: An Introduction to Linguistics in the 1990s. In: ARCHANGELI, D.; LANGENDOEN, D. T. (Ed.) Optimality Theory: An Overview. Malden, Mass.: Blackwell Publishers, 2003 [1997]. p. 1-32.

AZEVEDO, M. A Contrastive Phonology of Portuguese and English. Georgetown, USA: Georgetown University Press, 1981.

BEST, C. A Direct Realistic Perspective on Cross-Language Speech Perception. In: STRANGE, W. (Ed.). Speech Perception and Linguistic Experience: Issues in crosslanguage research. Timonium, MD: York Press, 1995. p. 229-273.

; TYLER, M. Nonnative and Second-Language Speech Perception: Commonalities and complementarities. In: BOHN, O.-S.; MUNRO, M. (Ed.). Language Experience in Second Language Speech Learning. In honor of James Emil Flege. Amsterdam: John Benjamins, 2007. p. 13-34.

BISOL, L. (Org.). Introdução aos estudos de fonologia do português brasileiro. 4. ed. Porto Alegre: EDIPUCRS, 2005.

. The Contrastive Nasality in Portuguese, 2008. Disponível em: <http://roa.rutgers.edu/files/1005-1208/1005-BISOL-0-0.PDF>. Acesso em: 13 abr. 2011.

BOERSMA, P. How we learn variation, optionality, and probability. Proceedings of the Institute of Phonetic Sciences, v. 21, p. 43-58. University of Amsterdam, 1997. 
; HAYES, B. Empirical tests of the Gradual Learning Algorithm. Linguistic Inquiry, v. 32, n. 1, p. 45-86, 2001.

; WEENINK, D. Praat: doing phonetics by computer: version 5.3.01. Amsterdam: University of Amsterdam, 2011. Disponível em: <http://www.fon.hum.uva.nl/praat/>. Acesso em: 5 nov. 2011.

BRADLEY, T. Sibilant Voicing in Highland Ecuadorian Spanish. Lingua(gem), v. 2.2, p. 942, 2005.

BROSELOW, E. et al. The Emergence of the Unmarked in Second Language Phonology. Studies in Second Language Acquisition, n. 20, p. 261-280, 1998.

CAGLIARI, L. C. Elementos de fonética do português brasileiro. São Paulo: Paulistana, 2007.

CALLOU, D.; MORAES, J.; LEITE, Y. A variação de /s, r/ em posição final de sílaba e os dialetos brasileiros. 1994 (ms.).

CAMARGO, V. S. Traços fonético-fonológicos do português para falantes do espanhol e do inglês: segmentos dificultadores para a aquisição do português brasileiro. 2009. 92 f. Dissertação (Mestrado em Filologia e Língua Portuguesa) - Universidade de São Paulo, São Paulo, 2009.

CEBRIAN, J. Catalan obstruents and opacity: A case for representational ambisyllabicity. In: SMALLWOOD, C.; BÉJAR, S. (Ed.). Toronto Working Papers in Linguistics. Toronto: University of Toronto, 1999. v. 17. p. 58-80.

CHOMSKY, N. A review of B. F. Skinner's Verbal Behavior. Language, v. 35, n. 1, p. 2658, 1959.

; HALLE, M. The Sound Pattern of English. Cambridge, MA: MIT Press, 1968.

CLEMENTS, G. N; HUME, E. V. The internal organization of speech sounds. In: J. Goldsmith (Ed.). The Handbook of Phonological Theory. London: Blackwell, 1995. p. 245306. 
COHN, A. Nasalisation in English: Phonology or Phonetics, Phonology, v. 10, n. 1, p. 43-81, 1993.

CORDER, S. The Significance of Learners Errors. IRAL, v. 5, n. 4, p. 161-170, 1967.

Error Analysis and Interlanguage. Oxford: Oxford University Press, 1981.

DAVIDSON, L. et al. The initial and final states: theoretical implications and experimental explorations of Richness of the Base. In: KAGER, R.; PATER, J.; ZONNEVELD, W. Constraints in Phonological Acquisition. Cambridge: Cambridge University Press, 2004. p. 321-368.

de LACY, P. Markedness: Reduction and Preservation in Phonology. Cambridge: Cambridge University Press, 2006.

DEMUTH, K. Markedness and the development of prosodic structure. NELS, v. 25, p. 13-25, 1995.

DUTRA, A. Aquisição do português como segunda língua: fenômenos de variação. Londrina: Cambé, 2009.

ECKMAN, F. Markedness and the Contrastive Analysis Hypothesis. In: IOUP, G; WEINBERGER, S.H. (Org.). Interlanguage Phonology: The acquisition of a second language sound system. Cambridge: Newbury House Publishers, 1987. p. 55-69.

The Structural Conformity Hypothesis and the Acquisition of Consonant Clusters in the Interlanguage of ESL Learners. Studies in Second Language Acquisition, v. 13, n. 1, p. 23-41, 1991.

EWEN, C. J.; HULST, H. van der. The phonological structure of words: An introduction. Cambridge: Cambridge University Press, 2001.

FERREIRA, E. Português do Brasil pronunciado por falantes nativos de inglês: uma análise à luz da Linguística Contrastiva. 2006. 206 f. Dissertação (Mestrado em Letras) Universidade Estadual de Londrina, Londrina, 2006. 
FERREIRA NETTO, W. Introdução à fonologia da língua portuguesa. São Paulo: Hedra, 2001.

FLEGE, J. Second-Language Speech Learning: theory, findings, and problems. In: W. STRANGE (Ed.). Speech Perception and Linguistic Experience: Issues in cross-language research. Timonium, MD: York Press, 1995. p. 229-273.

Assessing Constraints on Second-Language Segmental Production and Perception. In: MEYER, A.; SCHILlER, N. (Ed.). Phonetics and Phonology in Language Comprehension and Production, Differences and Similarities. Berlin: Mouton de Gruyter, 2003. p. 319-355.

GNANADESIKAN, A. Markedness and faifhfulness constraints in child phonology. In: KAGER, R.; PATER, J.; ZONNEVELD, W. Constraints in Phonology Acquisition. Cambridge: Cambridge University Press, 2004. p. 109-157.

GIMSON, A. C.; CRUTTENDEN, A. Gimson's Pronunciation of English. 7th edition. London: Hodder Education, 2008.

GRIJZENHOUT, J. Voicing and devoicing in English, German, and Dutch: evidence for domain-specific identity constraints. SFB 282 working paper no. 116, 2000. Two papers on constraint domains. Düsseldorf: HHU, 2000.

GUSSENHOVEN, C.; JACOBS, H. Understanding Phonology. London: Arnold Publishers, 2005 [1998].

HAMMOND, M. The Phonology of English: A Prosodic Optimality-Theoretic Approach. Oxford: Oxford University Press, 1999.

HANCIN-BHATT, B. Second Language Phonology in Optimality Theory. In: HANSEN EDWARDS, J. G.; ZAMPINI, M. L. (Ed.). Phonology and Second Language Acquisition. Amsterdam, Philadelphia: Benjamins, 2008. p. 117-148.

; BHATT, R. Optimal L2 syllables: Interaction of transfer and developmental effects.

Studies in Second Language Acquisition, v. 19, p. 331-378, 1997. 
HANSEN EDWARDS, J. G.; ZAMPINI, M. L. Introduction. In: HANSEN EDWARDS, J. G.; ZAMPINI, M. L. (Ed.). Phonology and Second Language Acquisition. Amsterdam, Philadelphia: Benjamins, 2008. p. 2-11.

HARRIS, J. Spanish Phonology. Cambridge, Mass.: MIT Press, 1969.

HAYES, B. Phonological Acquisition in Optimality Theory: The Early Stages. In: KAGER, R.; PATER, J.; ZONNEVELD, W. Constraints in Phonological Acquisition. Cambridge: Cambridge University Press, 2004. p. 158-203.

JONES, D. An outline of English Phonetics. Cambridge: Cambridge Univeristy Press, 1976.

KAGER, R. Optimality Theory. Cambridge: Cambridge University Press, 1999.

KENSTOWICZ, M. Base-identity and uniform exponence: alternatives to cyclicity. In: DURAND, J.; LAKS, B. (Ed.). Current trends in phonology: models and methods. Salford: University of Salford Publications, 1996. p. 363-393.

KRÄMER, M. Intervocalic s-voicing, geminates and the Richness of the Base in Veneto Italian. Rivista di Grammatica Generativa, v. 28, p. 71-85, 2003. Disponível em: $<$ http://www.hum.uit.no/a/kraemer/mk-rgg.pdf $>$. Acesso em: 02 jul. 2011.

KUHL, P. A New View of Language Acquisition. Proceedings of the National Academy of Science, v. 97, p. 11850-11857, 2000.

LADO, R. Linguistics across Cultures. Ann Arbor: University of Michigan, 1957.

LARSEN-FREEMAN, D. Chaos/Complexity Science and Second Language Acquisition. Applied Linguistics, v. 18, n. 2, p. 141-165, 1997.

LOMBARDI, L. Positional faithfulness and voicing assimilation in optimality theory. Natural Language and Linguistic Theory, v. 17, p. 267-302, 1999.

MAJOR, R. A Model for Interlanguage Phonology. In: IOUP, G.; WEINBERGER, S.H. (Org.). Interlanguage Phonology: the acquisition of a second language sound system. Cambridge: Newbury House Publishers, 1987. p. 101-24. 
Foreign accent: the ontogeny and phylogeny of second language phonology. Mahwah, NJ: Lawrence Erlbaum Associates, 2001.

MATEUS, M.; d'ANDRADE. The Phonology of Portuguese. Oxford, England: Oxford University Press, 2000.

MATTOS e SILVA, R. O português arcaico: fonologia, morfologia e sintaxe. São Paulo: Contexto, 2006.

MATTOSO CÂMARA JR., J. Estrutura da língua portuguesa. 40. ed. Petrópolis: Vozes, 2007 [1970].

MCCARTHY, J. A Thematic Guide to Optimality Theory. Cambridge: Cambridge University Press, 2002.

; PRINCE, A. Prosodic Morphology I: Constraint Interaction and Satisfaction. Report no. RuCCS-TR-3. New Brunswick, NJ: Rutgers University Center for Cognitive Science, 1993.

; PRINCE, A. Faithfulness and Reduplicative Identity. In: BECKMAN; WALSH DICKEY; URBANCZYK (Org.). Papers in Optimality Theory. Amherst, MA: Graduate Linguistic Student Association, 1995. p. 249-384.

MONAHAN, P. Evidence of transference and emergence in the interlanguage (DOC 4440701). Rutgers Center for Cognitive Science. 2001. Disponível em: $<$ http://roa.rutgers.edu>. Acesso em: 24 mar. 2011.

MYERS, S. Regressive voicing assimilation: Production and perception studies. Journal of the International Phonetic Association, v. 40, n. 2. The University of Texas at Austin, p. 163-179, 2010.

NESPOR, M.; VOGEL, I. Prosodic Phonology. Dordrecht: Foris, 1986.

PARADIS, C.; PRUNET, J. Nasal Vowels as Two Segments: Evidence from Borrowings. Language, v. 76, n. 2, p. 324-357, 2000. 
PATER, J. Minimal violation and phonological development. Language Acquisition, v. 6, p. 201-253, 1997.

PRINCE, A; SMOLENSKY, P. Optimality Theory: constraint interaction in generative grammar. Baltimore: The Johns Hopkins University, 1993.

PULLEYBLANK, D. Optimality Theory and Features. In: ARCHANGELI; LANGENDOEN (Org.). Optimality Theory: An overview. Malden: Blackwell Publishers, 1997. p. 59-101.

QUINTANILHA, R. A epêntese no português brasileiro (L2), em segmentos plosivos em codas mediais, por falantes nativos do espanhol colombiano (L1): uma análise via Teoria da Otimidade Estocástica e Gramática Harmônica. 2011. 180 f. Dissertação (Mestrado em Letras) - Universidade Católica de Pelotas, Pelotas, 2011.

RICE, K. Markedness in Phonology. In: de LACY, P. (Ed.). The Cambridge Handbook of Phonology. Cambridge: Cambridge University Press, 2007. p. 79-97.

ROACH, P. English Phonetics and Phonology. Cambridge: Cambridge University Press, 1991

ROCA, I.; JOHNSON, W. A Course in Phonology. Oxford e Malden, MA: Blackwell Publishers, 1999.

SANKOFF, D. et al. Goldvarb X: A variable rule application for Macintosh and Windows. Toronto, CA: Department of Linguistics, University of Toronto, 2005. Disponível em

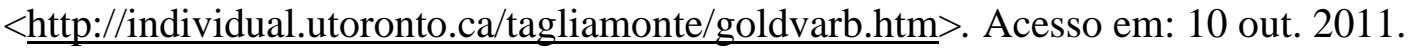

SANTOS, R. Aquisição prosódica do português brasileiro de $\mathbf{1}$ a $\mathbf{3}$ anos: padrões de palavra e processos de sândi externo. 2007. 213 f. Tese (Livre-Docência) - Universidade de São Paulo, São Paulo, 2007.

SCOVEL, T. A Time to Speak: A psycholinguistic inquiry into the critical period for human speech. New York: Newbury House/Harper e Row, 1988.

SELINKER, L. Interlanguage. IRAL. Oxford, v. 10, n. 3, p. 209-231, 1972. 
SELKIRK, E. The syllable. HULST, H. V. D.; SMITH. The structure of phonological representations (part II). Foris, Dordrecht, p. 337-383, 1982.

SILVA, C. Aquisição da regra de assimilação de vozeamento em português brasileiro. 2008. 161 f. Dissertação (Mestrado em Linguística) - Universidade de São Paulo, São Paulo, 2008.

SMITH, C. The devoicing of /z/ in American English: effects of local and prosodic context. Journal of Phonetics, v. 25, p. 471-500, 1997.

SMOLENSKY, P. The initial state and 'richness of the base' in Optimality Theory. Technical Report JHU-CogSci-96-4. Baltimore: Cognitive Science Department, Johns Hopkins University, MD, 1996.

TENANI, L. Domínios prosódicos no português do Brasil: implicações para a prosódia e para a aplicação de processos fonológicos. 2002. 331 f. Tese (Doutorado em Linguística) Universidade Estadual de Campinas, Campinas, 2002.

TESAR, B.; SMOLENSKY, P. Learnability in Optimality Theory (long version). ROA - 156, 1996. [http://ruccs.rutgers.edu/roa.html]

Learnability in Optimality Theory. Cambridge, MA: MIT Press, 2000.

TRUBetZKOY, N. Principles of Phonology. Tradução de C. A. M. Baltaxe. Berkeley: University of California Press, 1969 [1939].

WELLS, C. Accents of English 2: The British Isles. Cambridge: Cambridge University Press, 1982.

WETZELS, W.; MASCARÓ, J. The typology of voicing devoicing. Language. Baltimore, v. 77, n. 2, p. 207-243, 2001. 